\title{
Reviews and syntheses: influences of landscape structure and land uses on local to regional climate and air quality
}

\author{
Raia Silvia Massad $^{1}$, Juliette Lathière ${ }^{2}$, Susanna Strada ${ }^{3}$, Mathieu Perrin ${ }^{4}$, Erwan Personne ${ }^{1}$, Marc Stéfanon $^{5}$, \\ Patrick Stella $^{4}$, Sophie Szopa ${ }^{2}$, and Nathalie de Noblet-Ducoudré ${ }^{2}$ \\ ${ }^{1}$ UMR ECOSYS, INRA AgroParisTech, Université Paris Saclay, 78850, Thiverval-Grignon, France \\ ${ }^{2}$ Laboratoire des Sciences du Climat et de 1'Environnement, LSCE/IPSL, CEA-CNRS-UVSQ, Université Paris-Saclay, \\ Gif-sur-Yvette, 91191, France \\ ${ }^{3}$ The Abdus Salam International Centre for Theoretical Physics - Earth System Physics Section, 34151 Trieste, Italy \\ ${ }^{4}$ UMR SAD-APT, AgroParisTech, INRA, Université Paris-Saclay, 75005, Paris, France \\ ${ }^{5}$ Laboratoire de Météorologie Dynamique, Ecole Polytechnique, IPSL Research University, Ecole Normale Supérieure, \\ Université Paris-Saclay, Sorbonne Universités, CNRS, Route de Saclay, 91128 Palaiseau, France
}

Correspondence: Raia Silvia Massad (raia-silvia.massad@inra.fr)

Received: 19 September 2018 - Discussion started: 8 October 2018

Revised: 11 April 2019 - Accepted: 26 April 2019 - Published: 11 June 2019

\begin{abstract}
The atmosphere and the land surface interact in multiple ways, for instance through the radiative-energy balance, the water cycle or the emission and deposition of natural and anthropogenic compounds. By modifying the land surface, land use and land cover changes (LULCCs) and land management changes (LMCs) alter the physical, chemical, and biological processes of the biosphere and therefore all land-atmosphere interactions, from local to global scales. Through socio-economic drivers and regulatory policies adopted at different levels (local, regional, national, or supranational), human activities strongly interfere in the land-atmosphere interactions, and those activities lead to a patchwork of natural, semi-natural, agricultural, urban, and semi-urban areas. In this context, urban and peri-urban areas, which have a high population density, are of particular attention since land transformation can lead to important environmental impacts and affect the health and life of millions of people. The objectives of this review are to synthesize the existing experimental and modelling works that investigate physical, chemical, and/or biogeochemical interactions between land surfaces and the atmosphere, therefore potentially impacting local/regional climate and air quality, mainly in urban or peri-urban landscapes at regional and local scales.

The conclusions we draw from our synthesis are the following. (1) The adequate temporal and spatial description of land use and land management practices (e.g. areas con-
\end{abstract}

cerned, type of crops, whether or not they are irrigated, quantity of fertilizers used and actual seasonality of application) necessary for including the effects of LMC in global and even more in regional climate models is inexistent (or very poor). Not taking into account these characteristics may bias the regional projections used for impact studies. (2) Landatmosphere interactions are often specific to the case study analysed; therefore, one can hardly propose general solutions or recommendations. (3) Adaptation strategies, proposed after climatic impacts on the targeted resource have been derived, are often biased as they do not account for feedbacks on local/regional climate. (4) There is space for considering atmospheric chemistry, through land-atmosphere interactions, as a factor for land management, helping to maintain air quality and supporting ecosystem functioning. (5) There is a lack of an integrated tool, which includes the many different processes of importance in an operational model, to test different land use or land management scenarios at the scale of a territory.

\section{Introduction}

The Earth's atmosphere is an envelope of gases, liquid, and solid particles that provides essential conditions for life to thrive on Earth. Via its composition and exchanges with 
the land surface, the Earth's atmosphere regulates the physical climate around us and is as indissociable part of every ecosystem and a limited resource. Today, facing global changes in terms of climate, atmospheric composition, biodiversity, and demography, there is a growing demand to preserve a standard quality of life. Conversely, there is an increasing pressure on natural and human-shaped ecosystems to increase production and meet the nutritive and recreational demands of an expanding population. To maintain liveable conditions on Earth, it is important to understand the delicate balance between physical, chemical, and biological processes, and their interactions, which involve the atmospheric envelope and related surface systems (water, soil, flora, fauna, concrete, etc.) at local, regional, and global scales.

The atmosphere and the land surface interact in multiple ways, such as through the radiative-energy balance (Suni et al., 2015), the water cycle (Pielke et al., 1998), or the emission and deposition of natural and anthropogenic compounds (Arneth et al., 2010). Land use and land cover changes (LULCCs) (e.g. deforestation en afforestation, urbanization, cultivation, drying of wetlands) and land management changes (LMCs) (e.g. no-till agriculture, double-cropping, irrigation, cover crops) alter the land surface by modifying the physical properties (e.g. surface albedo, emissivity, and roughness), the chemical emission-deposition potential of land surfaces, and the biological equilibrium of living organisms and soils. Finally, LULCCs and LMCs affect the physical and chemical interactions between the land surface and the atmosphere, the atmospheric composition, and lastly the Earth's climate (Perugini et al., 2017), at local to global scales. The importance of LULCCs on the global climate is widely acknowledged, and global climate models (GCMs), which work at scales of 50-100 km, now integrate LULCC scenarios to investigate future climates (Jones et al., 2014). However, there is an increasing need to understand the effects on climate of LULCCs and LMCs operating at the regional, local, and even territorial scales, and hence to implement LULCC and LMC scenarios in climate models working at finer resolutions (i.e. regional climate models, RCMs) to explore their effects on the regional-local climate.

Today, human activities largely shape landscapes, resulting in a patchwork of natural, semi-natural, agricultural, urban, and semi-urban/peri-urban areas at scales smaller than a hectokilometre (Allen, 2003). The land surface is thus strongly sensitive to socio-economic drivers and influenced by regulatory policies adopted at the local, regional, national, or supranational scales. In this way, human activities strongly interfere in the land-atmosphere interactions and consequently influence climate and air quality at various geographical scales.

Recently, several reviews have examined the interactions between LULCCs and air quality and/or climate change.

Pielke et al. (2011) and Mahmood et al. (2014) reviewed the direct influence of LULCCs on regional climate, through biophysical processes, i.e. the modification of the water, energy, and radiative exchanges between the Earth's surface and the atmosphere's lower boundary from local to regional scales. Based on both observed and modelled data, the authors conclude that LULCCs affect local and regional climate, and, more significantly, the areal coverage of the landscape conversion determines the potential of LULCCs to effectively influence the mesoscale and regional climate.

Arneth et al. (2010, 2012), and more recently Heald and Spracklen (2015), mainly focused on the chemical effects. Arneth et al. (2010) looked at the picture from a global perspective with no special focus on LULCCs. They put forward that feedbacks between the terrestrial biosphere and the atmosphere cannot be ignored from a climate perspective and that our limited understanding of the processes involved implies that none of the feedbacks studied will act in isolation but rather that the system is more complex. The authors warned that non-linearities and possible thresholds exist that should be elucidated before performing simulations with ecosystem-chemistry-climate models. Arneth et al. (2012) encourage the improvement of the representation of biological and ecological processes and bridging the gap between biogeophysical and socio-economic communities, corroborating the need for integrative investigations. Indeed, the authors claim that the level of description for the different processes and interactions involved can significantly modify the projections of land-atmosphere exchanges (physical and chemical) performed with models.

Heald and Spracklen (2015) reviewed the interactions between LULCCs and atmospheric chemistry, with a focus on short-lived atmospheric pollutants, mainly biogenic volatile organic compounds (BVOCs), soil nitrogen oxides $\left(\mathrm{NO}_{x}\right)$, dust, smoke, bioaerosols, and ozone $\left(\mathrm{O}_{3}\right)$, and their subsequent radiative effects on global and local climates. The authors estimate that land use change (LUC) can cause a regional direct radiative effect of $\pm 20 \mathrm{~W} \mathrm{~m}^{-2}$. They identified several gaps of knowledge particularly linked to the aerosol effects on the regional radiative balance and emission variability due to different vegetation types. Other identified uncertainties are the future evolution of agricultural practices as well as the lack of connection between the different atmospheric species or process responses to LULCCs.

More recently, some studies have focused on the impact of small-scale changes, especially urbanization, on climate, and air quality. The work led by Jacobson et al. (2019), for instance, investigated the impact of urbanization in two cities, New Delhi and Los Angeles, on weather, climate and air quality over the 2000-2009 period. The authors applied satellite and road data to assess the extension of urban and road areas, a 1-year inventory for anthropogenic and natural emissions, together with a global-through-urban nested climateweather-air pollution model (GATOR-GCMOM). Changes in natural emissions related to meteorology were accounted for in this approach. For both New Delhi and Los Angeles, they concluded that urbanization has led to an increase in sur- 
face roughness, shearing stress, and vertical turbulent kinetic energy and concurrently to a decrease in near-surface and boundary layer wind speed, thus worsening pollution levels. This study shows that urbanization could have had significant impacts on both meteorology and air quality. Putting these results in a larger regional context would give the possibility to quantify the impact of urbanization on air quality and climate of surrounding peri-urban and rural areas. In that respect, Zhong et al. (2018) investigated the impact of urbanization-induced land cover change and increase in anthropogenic emissions on the air quality of the megacity cluster of the Yangtze River Delta. The authors applied a regional climate-chemistry model (the Weather Research and Forecasting with Chemistry, WRF-Chem) coupled with an urban canopy model. A strong reduction of near-surface aerosol concentrations was estimated over urban regions, whereas particulate pollution increased over the surrounding rural areas. These results were partly due to the urban heat island effect, which increased the lower atmospheric instability and ventilation over the urban area, and therefore promoted the dispersion of pollutants from urbanized areas to their immediate vicinities. This study exhibits the tight links between processes (physical, chemical) and scales (local, regional; urban, peri-urban, and rural areas).

So far, beyond scientific literature, relatively little attention has been paid in spatial planning practices to the consequences of land-use-related decisions and measures on climate conditions and air quality at a local-regional scale. Spatial-planning concerns generally focus on the impacts of densely built-up areas on temperatures in urban contexts (Tam et al., 2015; Du et al., 2007), or on ways to improve the mitigation of climate change (i.e. to enhance the biospheric sink of carbon dioxide, $\mathrm{CO}_{2}$, or decrease its sources). Hence, to our knowledge, very few studies have (1) discussed altogether the different physical, chemical, and biological interactions between the land surface and the atmosphere, (2) focused on urban-/peri-urban areas at local-regional scales, and (3) been addressed by decision makers, stakeholders, and land planners.

Our objective is therefore to review the existing experimental and modelling works that investigate the effects of regional and/or local LULCCs and LMCs on physical, chemical, and/or biological interactions and feedbacks between the land surface and the atmosphere in rural, urban, and/or periurban landscapes. We refer to biological interactions as the exchange of chemical compounds that involve soils and biological organisms. The structure and content of this review is designed to be accessible to a large audience, including both specialists, such as scientists, and non-specialists, such as land planners, stakeholders, and decision makers. Nonspecialists may refer to the Supplement for a short review of the fundamentals of physics, chemistry, and biology that are at work in LULCCs and LMCs.

Our synthesis focuses on relatively short timescales (with respect to climate), ranging from a few days to a few years, and on local to regional spatial scales ranging from a few to a hundred kilometres. In the text, we will consistently use the word "climate" to refer to changes in mean weather values, considering impacts on local and meso-climate, whereas LULCC-induced impacts on global climate, especially via modification in greenhouse gas emissions and concentrations, are not the target of the present study and will not be covered here. Readers interested in these topics may refer to the studies of Le Quéré et al. (2018) and Saunois et al. (2016) for example. We pay special attention to the territorial dimension, understanding territory as the portion of the land surface delimited and developed by a community according to their needs; this includes the political authority as well as the use and developments made by a social group (Le Berre, 1992; Ginet, 2012). We mainly focus on human-driven changes to land use and land management and on peri-urban landscapes, relying on the fact that today $54 \%$ of the world's population lives in cities (United Nation, 2014) and that the annual rates of urban land expansion ranges from $2.2 \%$ in North America to $13.3 \%$ in coastal areas in China. Although today urban areas represent less than $0.5 \%$ of the Earth's total land area (around $650000 \mathrm{~km}^{2}$ ) (Schneider et al., 2009), estimations show that more than 5.87 million $\mathrm{km}^{2}$ of land is likely to be converted into urban areas by 2030 , and very likely (probability $>75 \%$ ) for $20 \%$ of this surface (Seto et al., 2012).

We firstly present land-atmosphere interactions for individual land cover and/or land management changes by discussing physical, chemical, and biological processes. We then explore possible interactions between these processes for a mosaic of different adjacent land uses and managements. We finally identify challenges and needs for current research and propose potential levers for action.

\section{Land cover and land use changes: history, dynamics, and challenges}

\subsection{Historical perspective}

Historically, research on land use intensification and population growth emerged after World War II in different disciplines such as human geography, ecological anthropology, or political ecology and concentrated on understanding agricultural changes. Later, concerns have been raised about the influence of the land surface on climate processes. In the mid-1970's, diverse studies highlighted the impact of land cover change on the land-atmosphere energy balance at local, regional, and global scales due to modifications in surface albedo (Otterman, 1974; Charney et al., 1975, 1977; Sagan et al., 1979). Lately, in the early 1980s, Woodwell et al. (1983) and Houghton et al. $(1985,1987)$ emphasized the role of terrestrial ecosystems as sources and sinks in the carbon cycle, pointing out the impact of the land cover on global climate. Because of the growing awareness that land surface influences various environmental processes and the climate, 
understanding the trends, patterns, and mechanisms of LULCCs became a fundamental issue in academic research (e.g. Ramankutty and Foley, 1999; Klein Goldewijk, 2001, 2011; Foley, 2005; Lambin and Geist, 2006; Ellis, 2011). In the 1990 s, the availability of land use data through remote sensing shifted the focus from land use intensification to land use and land cover studies (Erb et al., 2007; Verburg et al., 2011). More recently, due to its far-reaching, potentially detrimental ecological consequences, land use intensification has attracted the interest of the scientific community at large (Erb et al., 2013).

\subsection{Land use and land cover change}

Although land change may be one of the most ancient of all human-induced impacts on the environment, the Earth's land surface has never been altered by anthropogenic activity at the pace, magnitude, and extent experienced over the past few centuries (Lambin et al., 2001). On the basis of distinct studies, it can be estimated that roughly 12 million $\mathrm{km}^{2}$ of forests and woodlands has been cleared over the last 3 centuries, representing approximately a $20 \%$ decrease in forest cover: Richards (1990) estimated a 11.7 million $\mathrm{km}^{2}$ loss from 62.2 to 50.5 million $\mathrm{km}^{2}$ - between 1700 and 1980, Ramankutty and Foley (1999) indicated an 11.35 million $\mathrm{km}^{2}$ loss - from 55.27 to 43.92 million $\mathrm{km}^{2}$ - between 1700 and 1992, and Klein Goldewijk (2001) mentioned a 12.9 million $\mathrm{km}^{2}$ loss - from 54.4 to 41.5 million $\mathrm{km}^{2}$ - between 1700 and 1990. Although huge variations can be noticed between studies, notably because of land use/land cover definition and classification issues, similar trends have been reported regarding changes in natural areas (steppes, savannas, grasslands, shrublands, tundras, and hot/ice deserts): Ramankutty and Foley (1999) mentioned a 7.3 million $\mathrm{km}^{2}$ loss - from 73.2 to 65 million $\mathrm{km}^{2}$ - between 1700 and 1992 while Klein Goldewijk (2001) assessed a 25 million $\mathrm{km}^{2}$ loss - from 71.9 to 46.9 million $\mathrm{km}^{2}$ - between 1700 and 1990. In his review on the anthropogenic transformations of the terrestrial biosphere, Ellis (2011) spatially quantified the temporal aspects of human transformations on the ecosystems (Fig. 1).

Such a focus has led us to consider, especially under the scope of an integrated land science, the various and complex interactions between human societies and the environment (Turner, 2002). The land cover - which can be understood as one biophysical attribute of the surface (Turner et al., 1995) - is now predominantly dependent on the land use - which can be understood as the activity human societies have used the land for in accordance with economic, cultural, political, historical and land tenure considerations (Turner et al., 1995). On the world's ice-free land surface of approximately 130.1 million $\mathrm{km}^{2}$, the area directly reconfigured by human action as of 2007 has been estimated at $53.5 \%$ (Hooke and Martin-Duque, 2012).
This decline of natural ecosystems is essentially due to the conversion of forests, savannas, and grasslands into agricultural lands. The global areas of croplands and pastures increased significantly since 1700 with estimated extension from 12.3 million (Goldewijk, 2011, 1700-2000 period) to 14.75 million $\mathrm{km}^{2}$ (Pongratz et al., 2008; 1700-1992 period). By combining the results of different studies addressing this land transformation issue, Hooke and Martin-Duque (2012) estimated that, today, croplands and pastures represent, respectively, $12.8 \%$ and $25.8 \%$ of the world's ice-free land surface (Fig. 2).

Finally, the land transformation related to urban development and infrastructure expansion must be pointed out. A total of 8.4 million $\mathrm{km}^{2}$ can be classified as urban areas, rural housing, business areas, highways, or roads (Hooke and Martin-Duque, 2012). Even if increasing, commonly at the expense of agricultural land (Döös, 2002), this number represents only about $6.46 \%$ of the world's ice-free land surface. However, such a land transformation can strongly affect environmental processes at local and/or regional scales and therefore affect the health and life of millions of people, given the human density in the areas impacted (Ermert et al., 2012; Jagger and Shively, 2014).

\subsection{Land use intensification}

Another aspect of land use that affects the environment is land use intensification. In the scientific literature, there is no unique definition of land use intensification or land use intensity, even though the concept is increasingly referred to. The diversity of definitions reflects on the one hand a disciplinary diversity and, on the other, a certain relationship between humans and nature (Lindenmayer et al., 2012; Erb et al., 2013, 2016). From these two different contexts two distinct definitions of land use intensification emerge. The first comes from an agricultural point of view where land use intensification is simply defined as the increasing production from the same land by additional inputs in terms of labour, energy, fertilizer, and water (Erb et al., 2009; Krebs et al., 1999). Most of the time this involves developed agricultural techniques and an increased amount of input to the ecosystem (fertilizers, pesticides, etc.) (Lindenmayer et al., 2012). The land use intensification via production is thus operated in a neutral way on land area where intensification is the means by which gains are made using increased inputs per unit land area (Moller et al., 2008). However, it can involve a land use change in the case of the implantation of bioenergy crops, for example. As a second definition, land use intensification can also be seen from an ecological or biodiversity point of view as the increasing transformation of the land away from the original habitat. From this point of view, land use intensification is accompanied by landscape and ecosystem simplification, from complex natural systems to simplified agricultural ecosystems (the more one moves toward intensification, the more the other tends to move towards landscape uniformity 


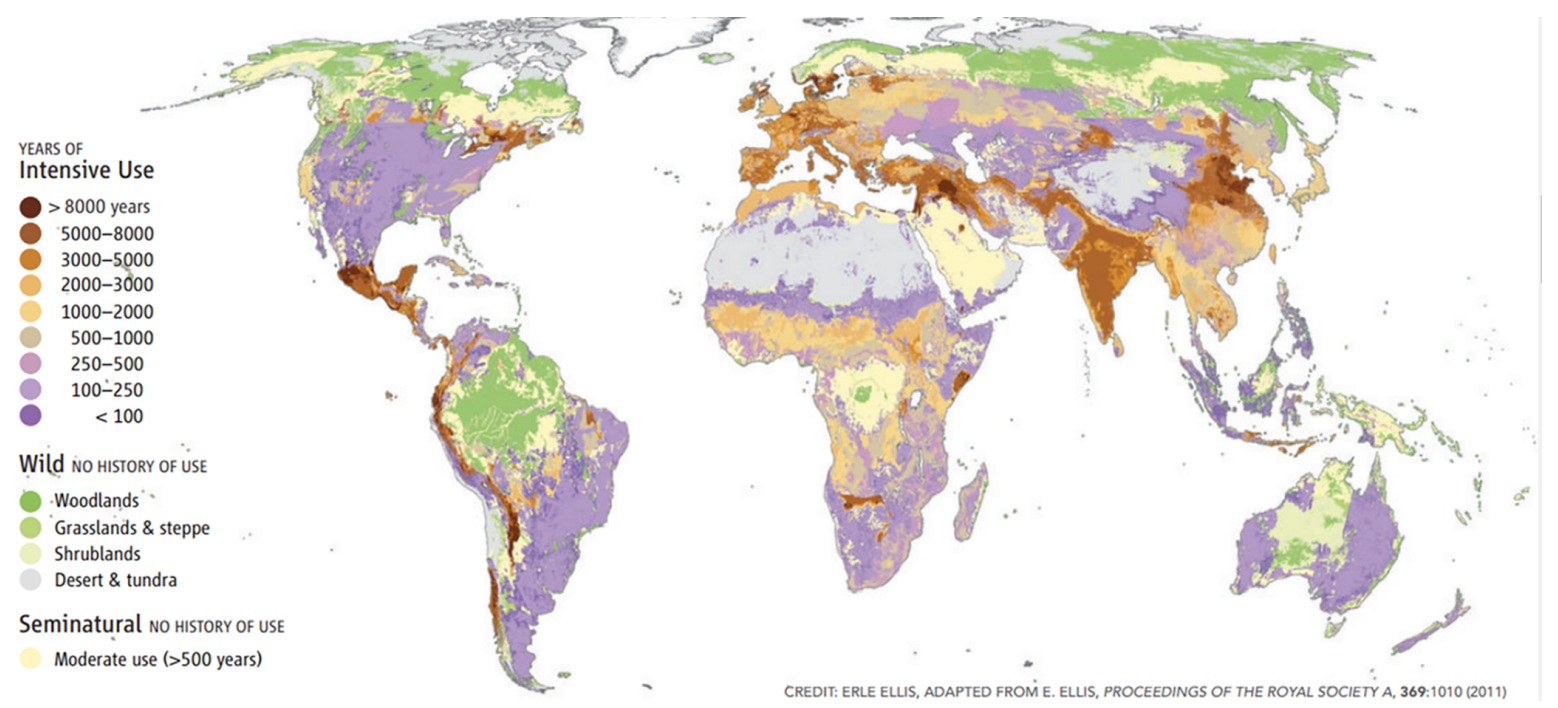

Figure 1. Anthropogenic transformation of the terrestrial biosphere showing the number of years of intensive use from Ellis (2011).

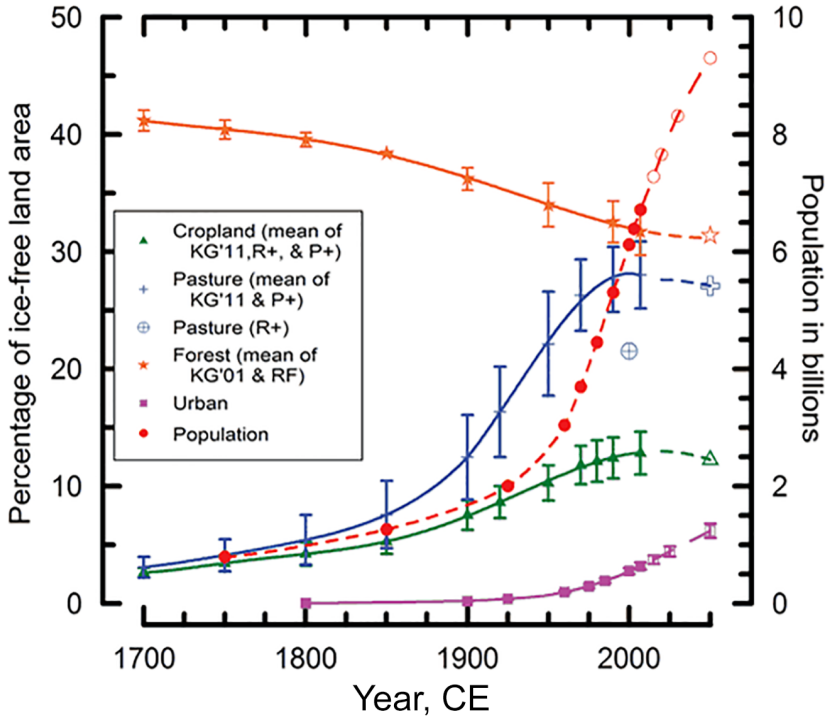

Figure 2. Adapted from Hooke and Martin-Duque (2012). Changes in land use through time (closed symbols) with extrapolations to $2050 \mathrm{CE}$ (open symbols).

in a reduction of biodiversity), or to urbanization (Flynn et al., 2009). This type of intensification is, however, never neutral on land area and systematically involves a LULCC. The difference between this view of land use intensification and LULCC is that the change is always towards a more humanshaped system, whereas LULCC can occur in the opposite direction by afforestation, restoration, etc.

As a result, it is very difficult today to draw a picture of the dynamics behind or the evolution of land use intensification simply because there is no common definition and terminology and there are many knowledge gaps related to the underlying processes and determinants of the levels, patterns, and dynamics of land use intensity (Shriar, 2000; Erb, 2012). However, it is essential to (a) assess the impacts of those changes and intensifications and (b) have the tools to assess their influences on the biosphere and on biosphereatmosphere interactions. In the sections below, we review the documented effects on the atmospheric compartment from a physical, chemical, and biological point of view and classify them in two categories (Fig. 3): land cover change and land intensification (agricultural and urban).

\section{Human-driven land use and land management changes and their impact on climate and air quality}

\subsection{Land cover change}

Most historical LULCCs are considered to have globally decreased primary production and therefore had an impact on atmospheric $\mathrm{CO}_{2}$ concentrations and thus on global warming, as shown by Gruber and Galloway (2008). This can be explained by the fact that past LULCCs concerned primarily deforestation and the increase in urban areas, thus leading to lower ecosystem productivity and a release of soil and biomass-stored carbon to the atmosphere in the form of $\mathrm{CO}_{2}$. Moreover, LULCCs affect physical interactions between the land surface and the atmosphere and atmospheric components other than $\mathrm{CO}_{2}$ such as reactive nitrogen compounds via their effects on the carbon $(\mathrm{C})$ and nitrogen $(\mathrm{N})$ cycles. This is mainly induced by the alteration of landatmosphere exchanges through changes in (i) stomatal conductance, (ii) deposition and adsorption on the leaf surfaces and cuticles, which varies according to plant species, (iii) the canopy architecture and its physical properties (leaf area, tree height), and (iv) availability of free soil water, which affects 


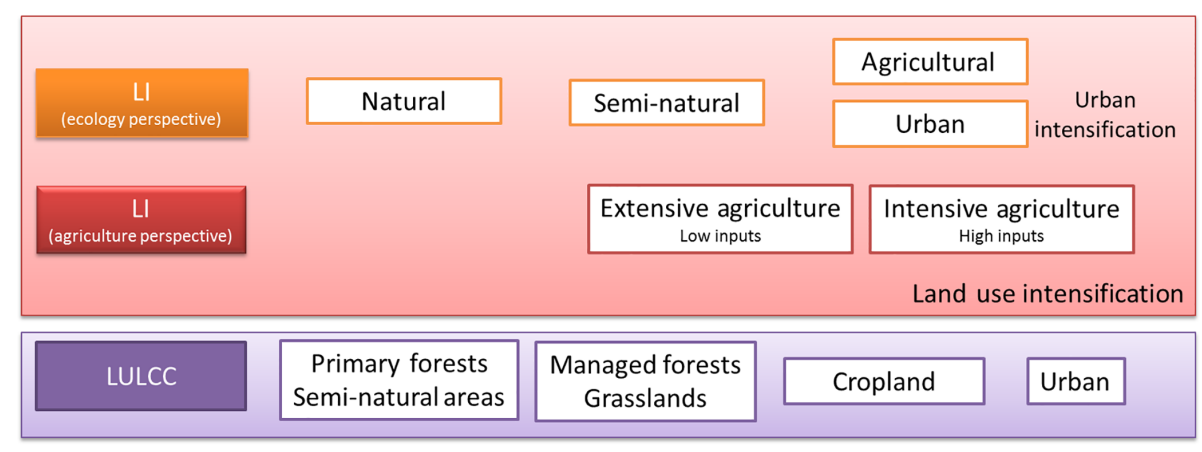

Natural Anthropized

Figure 3. Main changes in LULCC and LI (land use intensification) from an anthropic perspective and their classification relative to the sections of this paper.

the production and the exchange of certain compounds, as illustrated below by some examples.

\subsubsection{Deforestation-afforestation}

Deforestation has been practiced for tens of thousands of years for agriculture, grazing, cultivation, and urban purpose. However, over the last 33 centuries deforestation has drastically increased, with around 12 million $\mathrm{km}^{2}$ of forests cleared and 40 million $\mathrm{km}^{2}$ remaining today (Ramankutty and Foley, 1999; Klein Goldewijk, 2001; http://www.fao.org/forestry/ fra/41256/en/, last access: 22 May 2019).

From a physical perspective, several studies investigated the effects on climate of deforestation, or of its opposite (afforestation), mainly via a modelling approach. These studies compare the effects on climate of changes between current and pre-industrial potential vegetation, under the hypothesis of no human activities. Among its biogeophysical effects on climate, deforestation has contrasting effects on air temperature that depend on the latitude and the vegetation types involved (Claussen et al., 2001; Snyder et al., 2004; Gibbard et al., 2005; Bala et al., 2007; Betts et al., 2007; Jackson et al., 2008; Davin and de Noblet-Ducoudré, 2010; BeltrànPrzekurat et al., 2012). At high latitudes, deforestation triggers a winter and spring surface cooling due to changes in the radiation budget that compensate, at the annual scale, for the summer warming resulting from decreased latent heat flux (i.e. evaporation). In particular in boreal regions, forest removal strongly increases the surface albedo. Indeed forests mask the snow as opposed to herbaceous vegetation (Chalita and LeTreut, 1994; Betts et al., 2001; Meissner et al., 2003; Randerson et al., 2006). At low latitudes, deforestation leads to a surface warming due to changes in the water cycle. Conversion of tropical rainforests to pasture lands (as in the Amazon Basin region) strongly modifies surface evapotranspiration and roughness since, compared to pasture lands, trees have a higher surface roughness that enhances surface fluxes and thus the evapotranspiration cooling efficiency (Shukla et al., 1990; Dickinson and Kennedy, 1992; Lean and Rowntree, 1997; von Randow et al., 2004; Nogherotto et al., 2013; Lejeune et al., 2015; Spracklen and Garcia-Carreras, 2015; Llopart et al., 2018). In the long term, reduced evapotranspiration and precipitation may lengthen the dry season in the tropics, thereby increasing the risks of fire occurrence (Crutzen and Andreae, 1990). At mid-latitudes, both albedo and evapotranspiration mechanisms are at work and compete against each other, as recently confirmed by satellite-based observation analysis (Li et al., 2015; Forzieri et al., 2017). Although studies over the mid-latitudes show somewhat contradictory results and the effect on air temperature (warming/cooling) remains unclear in temperate regions such as the Mediterranean Basin region and Europe (Gaertner et al., 2001; Heck et al., 2001; Anav et al., 2010; Zampieri and Lionello, 2011; Gálos et al., 2013; Stéfanon et al., 2014; Strandberg and Kjellström, 2019), in the Northern Hemisphere, the historical land cover change has very likely led to a substantial cooling (Brovkin et al., 1999, 2006; Bonan, 1997; Betts, 2001; Govindasamy et al., 2001; Bounoua et al., 2002; Feddema et al., 2005a), comparable in magnitude with the impact of increased greenhouse gases (Boisier et al., 2012; de Noblet-Ducoudré et al., 2012). However, a recent study combines present-day observations and state-ofthe-art climate simulations and shows that historical deforestation in North America and Eurasia has made the hottest day of the year warmer since pre-industrial times, contributing to at least one-third of the local present-day warming of heat extremes (Lejeune et al., 2018). In addition to modifying mean and extreme temperatures, deforestation-afforestation can also modify the hydrological cycle by enhancing or inhibiting convective clouds and precipitation in the overlying atmospheric column. Some studies show an enhancement of shallow cumulus clouds over deforested lands in Amazonia 
(Chagnon et al., 2004; Wang et al., 2009), while opposite results were found over deforested lands in southwest Australia (Ray et al., 2003). Two different mechanisms result from the interplay between the surface heat fluxes and the boundary layer structure (i.e. stability, temperature, and humidity): (1) dry soil and high sensible heat flux can increase the entrainment of cold air from the boundary layer top and finally increase shallow cloud cover by lowering the saturation threshold (Westra et al., 2012; Gentine et al., 2013). (2) Conversely, wet soil and high latent heat flux moisten the boundary layer and increase the relative humidity at its top in case of deforestation.

From a biological perspective, deforestation implies modifications in surface moisture and temperature that in turn might directly or indirectly affect decomposition rates and nutrient mineralization in soils (Dominski, 1971; Stone, 1973; Stone, 1979; Classen et al., 2015; Manzoni et al., 2012; Chen et al., 2014; Townsend et al., 2011; Bonan, 2008). As a result, both carbon and nitrogen release to the environment are forecasted to increase. The forest floor decomposes rapidly (Covington, 1976; Bormann and Likens, 1979) and, without forest regeneration, will eventually be partially eroded. The combination of increased decomposition (which consumes oxygen) and wetter soils (which slow oxygen diffusion) may also increase the occurrence of anaerobic microsites within the soils, which might contribute to methane $\left(\mathrm{CH}_{4}\right)$ emissions (Adji et al., 2014; Jauhiainen et al., 2016). Nitrogen can be lost to the atmosphere through ammonia $\left(\mathrm{NH}_{3}\right)$ volatilization, nitrous oxide $\left(\mathrm{N}_{2} \mathrm{O}\right)$ production during nitrification (Bremner and Blackmer, 1978; Veldkamp et al., 2009), or denitrification to $\mathrm{N}_{2} \mathrm{O}$ or atmospheric nitrogen $\left(\mathrm{N}_{2}\right)$ (Firestone et al., 1980; Neill et al., 2005; Lammel et al., 2015). Soil properties such as soil organic carbon or soil nitrogen cycling respond to deforestation with a large spatial variety from one system to another (Powers and Schlesinger, 2002; Chaplot et al., 2010; de Blécourt 2013). However, the largest emissions of non- $\mathrm{CO}_{2}$ greenhouse gases will probably result from agricultural use and management on deforested areas.

Finally, several studies show that there are feedbacks between tropical forests and climate change (Bonan, 2008). Carbon dioxide fertilization, for example, could have a positive effect by sustaining tropical forest growth (Lapola et al., 2009; Salazar and Nobre, 2010). This is exacerbated by $\mathrm{N}$ fertilization since tropical areas are not limited-N environments and $\mathrm{N}$ is increasing through atmospheric deposition in non-tropical areas (Magnani et al., 2007; Sutton et al., 2008; Samuelson et al., 2008; Jackson et al., 2009). Zaehle et al. (2011) showed that $\mathrm{N}$ inputs increased $\mathrm{C}$ sequestration by ecosystems, and Churkina et al. (2007) attributed 0.75$2.21 \mathrm{GtC} \mathrm{yr}^{-1}$ during the 1990 s to regrowing forests. However Yang et al. (2010) showed that the contribution of $\mathrm{N}$ fertilization is lower for secondary forest regrowth (Jain et al., 2013).
As a direct effect, afforestation inevitably leads to carbon loss from the system (Feddema et al., 2005b; Foley et al., 2005; Le Quéré et al., 2013; Houghton et al., 2012). However, large uncertainties remain on (i) how these altered ecosystems will react to induced global climate change (increased $\mathrm{CO}_{2}$ concentration, increased temperature, etc.), (ii) changes in the emissions of non- $\mathrm{CO}_{2}$ greenhouse gases $\left(\mathrm{N}_{2} \mathrm{O}, \mathrm{CH}_{4}\right)$, and (iii) changes in the exchange of reactive trace gases.

From a chemical perspective, afforestation directly affects BVOC emissions since trees are high BVOC emitters, as documented by Purves et al. (2004) over the eastern US by combining a BVOC emission model with vegetation changes as recorded by the USDA Forest Service Inventory Analysis (FIA) over surveyed forest plots. Over the target region, emissions of the main BVOCs (i.e. isoprene and monoterpene) have increased, especially under heatwave conditions (i.e. daily air temperature above $35^{\circ} \mathrm{C}$ ), due to increase in the forest leaf area mainly driven by human disturbance via harvesting and plantation management (i.e. often plantation forestry introduces high emitters), but as well by perturbing ecological succession with fires and pollution. Enhanced BVOC emissions from forests are likely to modify the $\mathrm{NO}_{x}-$ VOC $-\mathrm{O}_{3}$ regime; nevertheless the outcome critically depends on the fate of isoprene nitrates, whether they are a terminal or temporal sink of $\mathrm{NO}_{x}$ (Val Martin et al., 2015). Concerning fine-mode aerosols, summer levels of $\mathrm{PM}_{2.5}$ (i.e. particulate matter, PM, with aerodynamic diameters $\leq 2.5 \mu \mathrm{m}$ ) are predicted to increase with afforestation due to the formation of biogenic secondary organic aerosols (BSOAs) from BVOCs (Heald et al., 2008; Trail et al., 2015; Val Martin et al., 2015). As with afforestation, deforestation to create pasture or crop lands can also exacerbate $\mathrm{O}_{3}$ levels by increasing $\mathrm{NO}_{x}$ emissions from soil microbial activity, promoted with fertilization (Ganzeveld and Lelieveld, 2004; Trail et al., 2015); in winter, the enhanced $\mathrm{NO}_{x}$ levels favour nitrate aerosol production, while in summer deforestation decreases aerosol deposition, by reducing surface roughness. In conclusion, fine-mode aerosols such as $\mathrm{PM}_{2.5}$ may increase yearround under deforestation (Trail et al., 2015).

Under an increasing demand and interest for fast-growing plants for food production, cattle feed, domestic products, and biofuels, plantations are rapidly expanding all over the world. The choice of crop or tree type influences BVOC emissions and the resulting $\mathrm{O}_{3}$ and BSOA levels (Hewitt et al., 2009; Ashworth et al., 2012; Warwick et al., 2013; Stavrakou et al., 2014). This is the case of oil palm crops that show much larger BVOC emission potentials compared to primitive forests (from 3 to 10 times higher for isoprene; Hewitt et al., 2009, and Fowler et al., 2011). In South East Asia, increasing BVOC emissions from oil palm plantations interplay with increasing $\mathrm{NO}_{x}$ emissions resulting from the spread in mechanization, fossil fuel use, and fertilizer application associated with the oil palm industry. The complex interaction between BVOC and $\mathrm{NO}_{x}$ finally enhances 
$\mathrm{O}_{3}$ levels at local-regional scales (Goldammer et al., 2009; Hewitt et al., 2009; Silva et al., 2016; Harper and Unger, 2018), with even transboundary effects (i.e. downwind regions) (Warwick et al., 2013). Similarly to South East Asia and oil palm production, the expansion of biofuel production in Europe could modify future LULC to satisfy the increasing demand for renewable energy sources (Beringer et al., 2011). Among biofuel feedstock, crops such as miscanthus or second-generation plantations such as poplar show higher isoprene emission potential compared to European native species. The conversion of European grass- and croplands into biofuel plantations may affect summer $\mathrm{O}_{3}$ levels with effects that strongly depend on the interaction between BVOC and $\mathrm{NO}_{x}$ emissions. For example, to limit the effects on $\mathrm{O}_{3}$ production of a steep increase in isoprene emissions $(\sim 45 \%)$ from conversion of $5 \%$ of European grassand croplands into poplar plantation, $\mathrm{NO}_{x}$ emissions should be reduced by $15 \%-20 \%$ (Beltman et al., 2013). Regarding Europe, Ashworth et al. (2013) showed that the extension of short-rotation coppice for biofuel feedstock could have small but yet important impacts on surface $\mathrm{O}_{3}$ concentrations, and subsequently on human mortality and crop productivity, since it would modify emitted compounds and their levels. Being BSOA precursors, enhanced BVOC emissions from afforestation are also involved in particulate matter pollution.

Using a large-scale chemistry-transport model for presentday climate, Ashworth et al. (2012) investigated the impact of realistic large-scale scenarios of biofuel feedstock production ( $\sim 100$ Mha plantations) in both the tropics and the midlatitudes on isoprene emissions, $\mathrm{O}_{3}$, and BSOA formation. These LULCCs drive an increase in global isoprene emissions of about $1 \%$, with a substantial impact on regional $\mathrm{O}_{3}$ levels and BSOAs. In the tropics, the expansion of oil palm plantations enhances BSOAs by $0.3 \mu \mathrm{g} \mathrm{m}^{-3}(+3 \%-$ $5 \%$, BSOA annual mean concentrations: $6-10 \mu \mathrm{g} \mathrm{m}^{-3}$ ). In the mid-latitudes, the establishment of short-rotation coppice increases BSOA concentrations up to $0.5 \mu \mathrm{g} \mathrm{m}^{-3}$ ( $+6 \%$, from $8 \mu \mathrm{g} \mathrm{m}^{-3}$ ).

\subsubsection{Wetland conversion-restoration}

Although wetland drainage is a relatively small proportion of the world's land surface, LULCC can have significant impacts on some areas. Wetland drainage for agriculture purposes has removed between $64 \%$ and $71 \%$ of natural wetlands since 1900 (Davidson, 2014).

From a physical perspective, only few studies have evaluated its impact on local and regional climate. The most documented case is that of south Florida (Pielke et al., 1999; Weaver and Avissar, 2001; Marshall et al., 2004a, b). During the 20th century, large wetland areas in south Florida were converted to large-scale crops (cereals), citrus growth, and fruit crops in general. Modelling studies show that current surface cover caused significant changes in temperature ex- tremes with increased length of freezing events and increased magnitude of frost (lower temperature), which severely reduced the agricultural production (Marshall et al., 2004a). During night-time, water vapour evaporates from the swamps and modifies the longwave radiation budget, resulting in a less rapid infrared cooling and less cooling by $+2{ }^{\circ} \mathrm{C}$ than for the current (drained) case. A similar study over Switzerland shows opposite results (Schneider and Eugster, 2007). The conversion of wetlands to extensive farming caused a nighttime warming and a daytime cooling of a few tenths of a degree Celsius. This temperature modification was explained by the alteration of soil thermal properties and by higher albedo in the current case. During the night-time, higher thermal conductivity of the current soils resulted in upward heat fluxes, which enhanced the temperature. In another vein, Mohamed et al. (2005) studied the effect of Sudd swamp on the Nile water flow and local climate. Due to the Sudd wetland, located in the upper Nile, a substantial amount of water is lost through evapotranspiration. In a drained Sudd scenario produced by a numerical experiment, the Nile flow just downstream the wetlands increases by $46 \mathrm{Gm}^{3} \mathrm{yr}^{-1}$ over a total of $110 \mathrm{Gm}^{3} \mathrm{yr}^{-1}$. However, evapotranspiration decreases, causing a temperature increase of $+4-6{ }^{\circ} \mathrm{C}$ during the dry season.

From a biological perspective, the drainage of peatlands and wetlands for agricultural use alters several characteristics of those areas and could thus be problematic (see Verhoeven et al., 2011, for a review). Especially in tropical areas, peatland draining releases some extra $\mathrm{CO}_{2}$ by oxidizing and subsiding peat soils used for growing oil palms (Immirzi et al., 1992; Maltby and Immirzi, 1993; Safford et al., 1998; Furukawa et al., 2005). Hoojer et al. (2006) estimate the emissions from Indonesian peatland draining at $516 \mathrm{MtC} \mathrm{yr}^{-1}$ (fires excluded). Conversely, since wetlands are a considerable source of $\mathrm{CH}_{4}$, their drainage will decrease emissions of $\mathrm{CH}_{4}$ and can thus be considered a carbon gain from that point of view (Bergkamp and Orlando, 1999; Maltby and Immirzi, 1993). However, this gain is counterbalanced by increased $\mathrm{N}_{2} \mathrm{O}$ emissions, due to the lowering of the water table (Kasimir-Klemedtsson et al., 1997; Maljanen et al., 2010). On the other hand, changes in vegetation and therefore growth in those drained areas involve an increased carbon sink from vegetation. However, this additional sink rarely compensates for the greenhouse gas (GHG) losses resulting from $\mathrm{C}$ losses from the soil (Yeh et al., 2010; Yew et al., 2010).

From a chemical perspective, on top of decreasing $\mathrm{CH}_{4}$ emissions, wetland drainage may probably increase $\mathrm{NO}_{x}$ emissions, and modify emissions of other compounds such as BVOCs, due to vegetation change, which together could contribute to significant changes in the atmospheric chemical composition. Overall, the impact of wetland conversion on compound emissions other than $\mathrm{CH}_{4}$ and on atmospheric chemistry has been poorly investigated. 


\subsection{Land intensification}

\subsubsection{Urbanization}

Urbanization results in the replacement of (pseudo-)natural ecosystem vegetation by more or less dense and impervious built-up environments. Human activities concentrated in these areas are responsible for additional heat and gaseous releases in the atmosphere. Consequently, these LULCCs sharply modify the atmosphere, in terms of both climatic conditions and gas composition, which ultimately affect land-atmosphere exchanges and biogeochemical cycles.

From a physical perspective, urbanization results in a modification of surface radiative budget, energy balance, water balance, and land-atmosphere mass and energy exchanges (see Eqs. S1 to S5 in the Supplement), leading ultimately to (local) climate alteration in urban areas.

Firstly, urbanization affects each component of the radiative budget. On the one hand, the net radiation is potentially reduced due to the decrease in the incoming shortwave radiation that is screened out by a reflecting smog layer. In the dry season, in clear skies, Jauregui and Luyando (1999) observed that the incoming solar radiation over Mexico City was $21.6 \%$ lower than its suburbs. This difference could increase up to $30 \%$ under weak winds. However, the intensity of the reduction in incoming shortwave radiation was closely related to the day of the week (i.e. human activities) and meteorology (e.g. temperature, humidity, solar radiation), which both influence photochemical smog formation. Similarly, Wang et al. (2015) measured lower incoming shortwave radiation in Beijing compared to its surroundings, with values ranging between $3 \%$ and $20 \%$ depending on the season. Focusing on summer periods (June, July, August), Li et al. (2018) recorded lower $S \downarrow$ at urban stations compared to rural stations in the city of Berlin; the authors attributed this dimming effect to the thick aerosol layer observed over the city. Based on the analysis of global radiation measurements from the Global Energy Balance Archive (GEBA), Alpert et al. (2005) and Alpert and Kishcha (2008) showed a relationship between solar dimming, population density, and atmospheric pollution such as aerosols, which absorb and scatter the incoming solar radiation. Overall, Alpert and Kishcha (2008) demonstrated that at the surface shortwave radiation is $8 \%$ lower in urban compared to rural areas. Moreover, the net radiation is also potentially reduced by the enhanced outcoming longwave radiation due to a warmer urban environment (the so-called "urban heat island effect"; see below) since infrared radiations depend on surface temperature. On the other hand, urbanization also induces an increase in net radiation. Urbanization usually results in a decrease in surface albedo $(\alpha)$ and surface emissivities $\left(\varepsilon_{\mathrm{s}}\right)$ (Table 1), finally reducing both outgoing short- and longwave radiation. Although some building materials exhibit larger albedo and emissivity than (pseudo-)natural environments, most of them have lower ones, especially asphalt or other dark materials (e.g. Li et al., 2013; Alchapar et al., 2014; Rahdi et al., 2014). Yet, at the city scale, outgoing short- and longwave radiation is scattered and absorbed multiple times within urban canyons (i.e. light-trapping effect), thus contributing to both outgoing short- and longwave radiation reduction. Overall, both effects tend to compensate for each other and only a few differences in $Q^{*}$ have been observed between urban and rural environments on a yearly average (Oke and Fuggle, 1972; Christen and Vogt, 2004). Nevertheless, depending on the seasons and time of the day, larger net radiation has been observed in urban areas during daytime and in winter, when snow covers surrounding rural areas (Christen and Vogt, 2004).

Secondly, compared to the surrounding areas, an urban environment sharply modifies the way surface energy is dissipated (i.e. the energy partitioning between sensible and latent heat fluxes). In rural environments vegetation and pervious surfaces provide larger evapotranspiration rates (i.e. latent sensible heat flux), and therefore lower sensible heat flux, whereas in urban areas energy is mainly dissipated through sensible heat flux. A non-natural term, sensible heat flux, due to heat release by human activities (e.g. building heating or cooling), adds to a natural sensible heat flux, further increasing sensible heat flux in urban areas (Arnfield, 2003). As a result, the Bowen ratio is amplified in urban areas (Table 1). Such a large dissipation of energy through sensible heat flux, which transfers heat from the surface to the air, leads to the so-called urban heat island (UHI) effect, the most well-known alteration of (local) climate due to urbanization that corresponds to a warmer climate in urban environments compared to surrounding rural environments (around $2-3^{\circ} \mathrm{C}$ ). UHI is defined as a temperature difference between the city and its surroundings, depending on the local land use. Nevertheless, UHI intensity is sharply variable according to the time of day (e.g. Pearlmutter et al., 1999), the season (e.g. Eliasson, 1996; Zhou et al., 2014), the geographical location, spatial organization of the urban fabric (e.g. building size and density, human use, fraction of vegetation) (e.g. Emmanuel and Fernando, 2007; Hart and Sailor, 2009), and rural land use (e.g. forests, crops, bare soil) (Chen et al., 2006). Recently, Yao et al. (2019) combined satellitebased observations of land surface temperature (LST) and enhanced vegetation index and showed that rural greening has contributed by $+0.09^{\circ} \mathrm{C}$ per decade $(23 \%)$ over the period 2000-2017 to the increase in daytime surface UHI intensity (i.e. urban LST minus rural LST). By modifying the local energy budget, urbanization modifies the boundary layer structure and lastly influences the water budget. Urban signatures (e.g. change in magnitude, intensity, and spatial patterns) have been observed in precipitation (see Shepherd, 2005, and Pielke et al., 2007, for a review on urban precipitation). Moreover, complex urban terrain amplifies regional gradients in temperature, pressure, moisture, and wind that act as a source of vorticity for storm ingestion and development into tornadoes (Kellner and Niyogi, 2014). Moreover, 
Table 1. Typical values of snow-free albedo $(\alpha-\%)$, Bowen ratio $(\beta-\%)$, and roughness length $\left(z_{0}-\mathrm{m}\right)$ for various surface land cover types.

\begin{tabular}{|c|c|c|c|c|c|}
\hline & Bare soils & Grasslands & Forests & Crops & Urban areas \\
\hline$\alpha$ & $\begin{array}{l}0.14-0.28 \\
\text { (Matthews et al., 2003) }\end{array}$ & $\begin{array}{l}0.17-0.25 \\
\text { (Matthews et al., 2003; } \\
\text { Markvart et al., 2003) }\end{array}$ & $\begin{array}{l}0.08-0.18 \\
\text { (Matthews et al., 2003; } \\
\text { Markvart et al., 2003) }\end{array}$ & $\begin{array}{l}0.13-0.25 \\
\text { (Matthews et al., 2003; } \\
\text { Song, 1999) }\end{array}$ & $\begin{array}{l}0.09-0.27 \\
\text { (Taha, 1997; Brazel et } \\
\text { al., 2000; Santamouris, } \\
\text { 2013) }\end{array}$ \\
\hline$\beta$ & & $\begin{array}{l}0.4 \\
\text { (Teuling et al., 2010) }\end{array}$ & $\begin{array}{l}0.9-1.6 \\
\text { (Teuling et al., 2010) }\end{array}$ & & $\begin{array}{l}1.5-5 \\
\text { (Oke, 1982; Oberndor- } \\
\text { fer et al., 2007; Pearl- } \\
\text { mutter et al., 2009) }\end{array}$ \\
\hline$z_{0}$ & $\begin{array}{l}0.02-0.04 \\
\text { (Matthews et al., 2003; } \\
\text { Wiernga, 1993) }\end{array}$ & $\begin{array}{l}0.11 \\
\text { (Matthews et al., 2003; } \\
\text { Wiernga, 1993) }\end{array}$ & $\begin{array}{l}0.91-2.86 \\
\text { (Matthews et al., 2003; } \\
\text { Wiernga, 1993) }\end{array}$ & $\begin{array}{l}0.05-0.18 \\
\text { (Matthews et al., 2003; } \\
\text { Wiernga, 1993) }\end{array}$ & $\begin{array}{l}0.5-2 \\
\text { (Kato and Yamaguchi, } \\
\text { 2005; Foken, 2008) }\end{array}$ \\
\hline
\end{tabular}

urban areas can attenuate, split, or deflect extreme storm events (e.g. Lorenz et al., 2019) and modify their intensity and occurrence. Over the Beijing metropolitan area, $60 \%-$ $95 \%$ of the selected weather stations show that the intensity and occurrence of extreme rainfalls have slightly decreased throughout 1975-2015, periods with consecutive rainy days (CRDs) have lengthened, and the Julian dates of daily maximum precipitation have been delayed (Zhang et al., 2019). Furthermore, cities are important source of aerosols that help initiate thunderstorms (Haberlie et al., 2015). However, the joint study of UHI and urban pollution island is still in its infancy and the indirect radiative effect of aerosols (i.e. impact on cloud properties and formation) on UHI needs further investigations (Li et al., 2018).

To mitigate UHI-induced warming, vegetated or highly reflective roofs are being integrated in the built environment and have received a growing interest in climate modelling studies. Cool roofs absorb less incoming shortwave radiation than dark roofs. They decrease the local and regional summer surface temperature by $0.1-0.9^{\circ} \mathrm{C}$ (Millstein and Menon, 2011; Georgescu et al., 2012; Salamanca et al., 2016; Vahmani et al., 2016). Their impact on climate is not just limited to surface energy budget as, for example, precipitation decrease was put forward in a modelling framework (Georgescu et al., 2012). Benefits from green roofs are analogous to cool roofs, as vegetation contributes to cooling via increased albedo and water evapotranspiration. In situ experiments with different species have surface temperature differences up to $3^{\circ} \mathrm{C}$ (MacIvor and LundHolm, 2011). However at the regional scale and over urban areas, simulated cooling is greater for the cool roofs relative to the green roofs because of the vegetation seasonality and sensitivity to dryness (Georgescu et al., 2014).

From a biological perspective, at a local scale, the development of urban areas and the related activities directly affect air quality and local temperatures, which leads to modifications in the biology of organisms. Studies based on the anal- ysis of tree traits along an urban-rural gradient showed that tree growth and phenology are affected by the vicinity of an urban area mainly due to increase in temperature (Gillner et al., 2014; Mimet et al., 2009; Dale and Frank, 2014), $\mathrm{CO}_{2}$ concentrations (Calfapietra et al., 2010; Ziska and George, 2004), ozone deposition (Gregg et al., 2003; MacKenzie et al., 1995), and through the enhanced effect on air quality via the increased emissions of BVOCs (Calfapietra et al., 2013; Lathière et al., 2006). Recent studies have also focused on the effects of soil waterproofing in urban areas that reduce water availability and exacerbate water stress in urban forests, significantly affecting growth (Vico et al., 2014; Volo et al., 2014; Scalenghe and Marsan, 2009).

From a chemical perspective, at local scales, urbanization directly affects both $\mathrm{O}_{3}$ and aerosol levels by increasing the number of emission sources on a limited area (e.g. traffic, domestic heating). In the literature, there is an increasing interest in the direct impacts of urbanization on air quality (special issues in the Atmospheric Chemistry and Physics journal related to the Megapoli-Paris 2009/2010 campaign and the MILAGRO and the City-zen projects, Baklanov et al., 2011, 2018; Zhu et al., 2019; Ooi et al., 2019), with a special focus on $\mathrm{O}_{3}$ levels, summer pollution (Nowak et al., 2000; Civerolo et al., 2007; Jiang et al., 2008), and the role of urban trees in $\mathrm{O}_{3}$ pollution via BVOC emission changes (Chameides et al., 1988; Cardelino and Chameides, 1990; Corchnoy et al., 1992; Benjamin et al., 1996; Taha, 1996; Benjamin and Winer, 1998; Yang et al., 2005; Taha et al., 2016; Livesley et al., 2016; Churkina et al., 2017; Bonn et al., 2018).

Increase in urban LU following population growth exacerbates $\mathrm{O}_{3}$ pollution during summer, mainly due to changes in $\mathrm{NO}_{x}$ emissions (Zhu et al., 2019). In the greater Houston area (Texas), under a projected increase in urban LU by $62 \%$, together with changes in anthropogenic and biogenic emissions, the number of extreme $\mathrm{O}_{3}$ days in August rose by up to 4-5 days, with LUCs contributing to a 2$3 \mathrm{~d}$ increase (Jiang et al., 2008). In the greater New York 
City region, future urban LU changes may enhance episodeaverage $\mathrm{O}_{3}$ levels by about $1-5 \mathrm{ppb}$ and episode-maximum $8 \mathrm{~h}$ ozone levels by more than $6 \mathrm{ppb}$ (Civerolo et al., 2007). In metropolitan regions, changes in $\mathrm{O}_{3}$ levels show a heterogeneous spatial pattern: they decrease in the urban core, likely due to high $\mathrm{NO}_{x}$ levels $\left(\mathrm{O}_{3}\right.$ titration), while they generally increase downwind of precursor sources (Civerolo et al., 2007; Jiang et al., 2008). In an urban environment, BVOC emissions from urban trees seem to have a negligible effect on summer $\mathrm{O}_{3}$ levels $(<1 \mathrm{ppb}$ compared to increases of 17 ppb due to urban LUCs; Nowak et al., 2000, vs. Jang et al., 2008). However, the effect of urban green areas on BVOC emissions and $\mathrm{O}_{3}$ pollution depends on tree species (Taha, 1996; Taha et al., 2016); for this reason, the choice of urban trees based on their BVOC potential may be addressed as a critical urban land management practice (Benjamin et al., 1996; Benjamin and Winer, 1998; Churkina et al., 2015; Calfapietra et al., 2015; Grote et al., 2016). For example, in Beijing, deciduous trees dominate $(76 \%)$ and some of the main species are high BVOC emitters (e.g. Sophora Japonica L., Populus tomentosa L., and Robinia pseudoacacia L.), which may favour a worsening in $\mathrm{O}_{3}$ pollution due to the rapid increase in $\mathrm{NO}_{x}$ emissions (Yang et al., 2005). In the Los Angeles metropolitan area, Corchnoy et al. (1992) measured BVOC emission rates of 11 tree species to underpin the selection of potential shade trees, whose planting should reduce the urban heat island effect. Accounting for California climate, the authors suggested the best (e.g. crape myrtle and camphor tree) and poor (e.g. liquidambar and carrotwood tree) choices for urban trees, and underlined that a large difference in BVOC emissions should be factored into decision-making about shade trees to plant. In California's South Coast Air Basin, medium- and high-emitting trees may lead to hazardous $\mathrm{O}_{3}$ levels ( $>50 \mathrm{ppbv}$ ) (Taha, 1996). In the same geographical area, the most effective scenario to reduce the peak ozone involves replacing 4.5 Mha of high BVOC emitters with low BVOC emitters, while to target all-hour ozone the best choice consists in planting 2.5 Mha of low BVOC emitters in urbanizing areas and switching 4.5 Mha from high- to low-emitting species (Taha et al., 2016). It is important to emphasize that, although BVOC concentrations are usually lower than anthropogenic volatile organic compound (AVOC) concentrations in urban areas, BVOCs react faster than AVOCs and can thus have significant effects in urban areas, as shown by Chameides et al. (1988) in the Atlanta metropolitan region.

At the regional scale, Chen et al. (2009) demonstrated that LULCCs can offset the impact of temperature on biogenic emissions and concluded that LULC evolution should be factored in the study of future regional air quality. Other than land use, land cover, and land management changes (LULCCs and LMCs) discussed here, changes in climate conditions and anthropogenic pollutant emissions (e.g. due to "clean air" policies) directly and indirectly influence air quality and interact in a non-linear fashion with LULC and
LMCs; for this reason the climate-emission-land system should be considered as a whole when studying changes in surface $\mathrm{O}_{3}$ and aerosols.

\subsubsection{Agriculture intensification}

The main aim of agricultural management is to increase productivity and therefore has an immediate effect on the agricultural ecosystem functioning (Tillman et al., 2002). Most of these agricultural practices will also have direct or indirect impacts on the environment other than the biosphere (e.g. atmosphere, water, soils) (Sutton, 2011). Agricultural intensification also enhances the export of organic matter from the affected ecosystems with consequences such as the reduction of carbon and nitrogen cycling and soil degradation and erosion (Mattson et al., 1997; Ruysschaert et al., 2004). Examples of agricultural intensification are the conversion of pasture or grasslands into agricultural land or including rotations of agricultural and grasslands.

\section{Irrigation}

From a physical perspective, among land management practices, irrigation is one of the most common all over the world, and it significantly modifies the surface water and energy budget. The amount of additional water put into the soils tends to increase the latent heat flux at the expense of sensible heat flux, leading to an irrigation cooling effect (ICE) of the ambient air. In California, for example, this effect was observed during daytime over a long-term dataset and estimated to several degrees $\left(-1.8\right.$ to $-3.2^{\circ} \mathrm{C}$ since the beginning of irrigation - Lobell and Bonfils, 2008; Bonfils and Lobell, 2007). However, there are two opposite indirect heating effects. First, the high-albedo desert is converted into a low-albedo vegetated plain (Christy et al., 2006), which results from a combination of crop planting and irrigation and can therefore be classified as a land cover change rather than an agricultural intensification. Second, the greenhouse warming is enhanced due to the increase in water vapour. The greenhouse effect is less important than the transpiration effect on temperature and dominates during the night-time. Several modelling studies assess both greenhouse and transpiration effects (Boucher et al., 2004; Sacks et al., 2009; Puma and Cook, 2010; Cook et al., 2011, 2015; Kueppers and Snyder, 2012) and highlight that locally the ICE may have partly masked the 20th century climate warming due to increased greenhouse gases (Kueppers et al., 2007). Meteorological studies suggest that irrigation can also lead to an increase in summer cloud cover and precipitation, as observed over the Great Plains region in the United States, downwind of the major irrigation areas (Segal et al., 1998; Adegoke et al., 2003; DeAngelis et al., 2010). In China, paddy cultivation requires water to stay on the ground during the rice-growing season, leading to a moistening of the land surface, an increase in the latent heat flux, and a decrease in the 
near-surface temperature from May to July in the Sichuan Basin (Sugimoto et al., 2019). Thiery et al. (2017) demonstrated that irrigation influences temperature extremes and leads to a pronounced cooling during the hottest day of the year $(-0.78 \mathrm{~K}$ averaged over irrigated land). In addition, this impact of irrigation on temperature is not limited to an agricultural environment as the same cooling effect has also been reproduced for urban irrigation in a water-scarce region (Los Angeles area), with the largest influence in low-intensity residential areas (average cooling of $1.64^{\circ} \mathrm{C}$ ) (Vahmani and Hogue, 2015). Affecting soil moisture and surface temperature, changes in irrigation could also affect soil processes and exchanges of greenhouse gases and chemically reactive compounds between the surface and the atmosphere (Liu et al., 2008). Performing irrigation experiments on the Inner Mongolian steppe, Liu et al. (2008) observed a significant sensitivity of the ecosystem $\mathrm{CO}_{2}$ respiration to increased water input during the vegetation period, whereas the effects on $\mathrm{CH}_{4}$ and $\mathrm{N}_{2} \mathrm{O}$ fluxes were much more moderate. In order to study the impact of irrigation on ozone and pollutants in the Central Valley of California, Li et al. (2016) implemented an irrigation method in the model WRF-Chem and showed an increase in surface primary pollutant concentrations within the irrigation zone. They also calculated an enhancement in the horizontal transport of ozone and other pollutants from irrigated to unirrigated areas near the ground surface. However, few studies have been published so far on this topic from a biological or chemical perspective, and the effect of irrigation on biological processes or on the atmospheric chemical composition therefore remains poorly quantified.

\section{Fertilization}

Since the Second World War, the use of synthetic N fertilizers largely increased, with half of the quantity ever used being applied in the last 20 years (Erisman et al., 2007). The growth of nitrogen fertilization threatens water sources (e.g. eutrophication of surface waters, pollution of groundwater, acid rains), soils (e.g. soil acidification), climate via GHG emissions, and air quality.

Few studies have investigated the impact of fertilizer use from a physical perspective, and yet physical interactions between the surface and the atmosphere could be affected. Based on a long-term experiment of fertilizer and amendment application running for 70 years, Pernes-Debuyser and Tessier (2004) observed that physical properties of plots were significantly affected, especially those related to soil-water relations. In spite of the preservation of their porosity, plots became more sensitive to the degradation of their hydraulic properties. Similarly, Hati et al. (2008) showed, in the case of an intensive conventional cultivation in subhumid tropics in India (acidic Alfisols), the importance of soil management practices in maintaining the soil physical environment, with a potential impact on soil aggregation, soil water retention, microporosity, available water capacity, or bulk density.
From a biological perspective, the additional source of nitrogen has different impacts on the atmosphere, mainly linked to an increase in reactive nitrogenous emissions $\left(\mathrm{NH}_{3}\right.$, $\mathrm{NO}_{x}$ ) (Fowler et al., 2009, 2013; Galloway et al., 2003) but also in emissions of a GHG such as $\mathrm{N}_{2} \mathrm{O}$. Increase in production also affects leaf area index and plant height and therefore surface properties and physical exchanges with the atmosphere. Finally, fertilization also influences soil microbial characteristics and, consequently, exchanges of several gaseous compounds (Marschner et al., 2003; Cinnadurai et al., 2013; Joergensen et al., 2010; Murugan and Kumar, 2013). Grassland usually stores considerable amounts of carbon in the soils, mainly due to a permanent plant cover and to a relatively large below-ground biomass (Bouwman, 1990; Casella, 1997). However, the amount of stored carbon and the emission of greenhouse gases depend on the management of this grassland (ploughing, fertilization, pasture, etc.) (Soussana et al., 2004; Lal, 2004) and on climatic conditions (Hu et al., 2001). Some studies suggest that increased nitrogen fertilization can enhance $\mathrm{C}$ storage in grassland. Conversely, nitrogen fertilization increases leaching and emissions of $\mathrm{N}_{2} \mathrm{O}$ and other nitrogen species (e.g. $\mathrm{NH}_{3}, \mathrm{NO}$ ) to the atmosphere, with negative consequences on air quality (Flechard et al., 2005; Senapati et al., 2014; Chabbi et al., 2015).

From a chemical perspective, the increase in $\mathrm{NH}_{3}$ emissions to the atmosphere can have a serious impact on air quality through the formation of secondary organic aerosols. Agricultural practices and techniques that reduce the evaporation of manure and urea and the use of $\mathrm{N}$ fertilizers help in lowering ammonia emissions from agriculture as documented in Europe, where $90 \%$ of the total ammonia emissions come from agriculture (-9\% over 1990-2002; Erisman et al., 2008). In China, where $\mathrm{N}$ fertilizer application rose by $271 \%$ over the 1977-2002 period, with an increase of $71 \%$ only in grain production (Ju et al., 2009), Ju et al. (2009) suggested reducing $\mathrm{N}$ application rates by $30 \%-$ $60 \%$. This agricultural management practice would still ensure crop yields and $\mathrm{N}$ balance in between rotations and would reduce economical costs for farmers, while substantially reducing $\mathrm{N}$ losses to the environment.

\section{Soil surface conditions}

From a physical perspective, several crop management techniques (e.g. cover crops, double-cropping, no tillage) have a direct effect on regional climate through changes in surfaceatmosphere fluxes and surface climate conditions, and are considered among geoengineering options. When tillage is suppressed, crop residues are left on the field, resulting in two counteracting mechanisms: albedo increases while evaporation reduces (Lobell et al., 2006; Davin et al., 2014; Wilhelm et al., 2015). Surface albedo increases by $10 \%$ and lowers hot temperature values by about $2{ }^{\circ} \mathrm{C}$; however the effect on the mean climate is negligible. Climate effect of two growing seasons per year has been largely untested. Only Lobell et 
al. (2006) have shown via modelling that this experiment has a small impact on temperature on multi-decadal timescales when compared to practices as irrigation. However, more recently Houspanossian et al. (2017) have observed through satellite imagery a difference in reflected radiation between single and double-cropping of up to $5 \mathrm{~W} \mathrm{~m}^{-2}$. Similar to a tillage/no-tillage mechanism, differences over South America were induced by a longer fallow period in the simple cropping case. Seed-sowing dates also likely plays a role in surface energy balance, due to the modification of the growing season length (Sacks and Kucharik, 2011).

Among agriculture practices, as an alternative to biomass burning and natural decomposition, the use of charcoal from biomass pyrolysis to enrich soils may reduce $\mathrm{CO}_{2}$ emissions. However, as a side effect, the resulting darker soil increases the local radiative forcing through albedo change and offsets the sequestration effect up to $30 \%$ according to Bozzi et al. (2015), who carried out the analysis based on observations of agricultural field albedo. Biochar has similar effects (Usowicz et al., 2016; Meyer et al., 2012).

From a chemical perspective, fallow lands are potential sources of dust and coarse aerosols $\left(\mathrm{PM}_{10}\right)$, especially in regions where gusty winds dominate. Insufficient crop residues on the surface and finely divided soils by multiple tillage operations expose fallow land to wind erosion, thus contributing to poor air quality (López et al., 2000; Sharrat et al., 2007). In addition, wind erosion is likely to reduce crop yields by removing the richest fraction of soils, reducing the water-holding capacity of soils and enhancing soil degradation. Compared to conventional tillage (i.e. mouldboard ploughing followed by a compacting roller), alternative or reduced tillage practices (e.g. chisel ploughing) prevent wind erosion during fallow periods in semiarid Aragon (López et al., 2007). In addition, reduced tillage improves soil protection by lowering the wind-erodible fraction of soil surface $(-10 \%)$, increasing fraction of soil covered with crop residues and clods $(+30 \%)$, and enhancing soil roughness (15\% compared to $4 \%$ under conventional tillage). These agricultural practices therefore have the potential to modify aerosol sources by modifying the state of surfaces.

From a biological point of view, the conditions of the soil surface and the management of crop residues highly affect soil quality as well as the functioning and the abundance of soil microorganisms (Smith et al., 2015, 2016). In terms of exchange with the atmosphere, this results in soil structural changes affecting soil porosity and directly influencing the emissions of $\mathrm{NO}_{x}$ and BVOCs (Gray et al., 2010; Bertram et al., 2005). Effects can also be seen on soil organic matter content and degree and rate of decomposition therefore affecting emissions of several nitrogen compounds therefore affecting GHG balance (emissions of $\mathrm{N}_{2} \mathrm{O}$ vs. storage of carbon) (Xia et al., 2018) and air quality $\left(\mathrm{NH}_{3}, \mathrm{NO}_{x}\right.$ emissions) (de Ruijter et al., 2010). Conversely, soil surface conditions also influence the deposition of $\mathrm{O}_{3}$ (Stella et al., 2019) and poten- tially other highly reactive atmospheric compounds such as pesticides (Alletto et al., 2010).

\section{Fire}

Fire is still largely used as a traditional agricultural practice (e.g. slash-and-burn agriculture, pest control, promotion of the growth of fresh grass for grazing) and to convert forests to pasture/croplands, especially in tropical regions (Yevich and Logan, 2003). On a local scale, intensive mechanized grain agriculture reduces the use of fire. However, the wealth generated from intensive agriculture may be reinvested in traditional extensive land uses that promote fire (Wright et al., 2004).

Generally, fires can impact soil colour, $\mathrm{pH}$, bulk density, and soil texture, and are therefore critical for physical surface-atmosphere exchanges, together with biological properties of soil such as species richness and microorganism content (Thomaz et al., 2014; Verma and Jayakumar, 2012; Savadogo et al., 2007). However the impact of fires from a physical or a biological perspective has been poorly investigated, especially regarding the long-term effect (Dooley and Treseder, 2012; Pressler et al., 2019).

From a chemical perspective, fire has impacts on both photochemical pollution $\left(\mathrm{O}_{3}\right.$ production) and aerosol loading. During fire episodes, $\mathrm{O}_{3}$ production switches from a VOCsensitive regime in nascent smoke plumes (i.e. first hours of burning and close to the ignition point) to a $\mathrm{NO}_{x}$-sensitive regime as the plume ages. In nascent smoke plumes $\mathrm{NO}_{x}$ levels are high and photochemical activity is low. Smoke plume ageing decreases $\mathrm{NO}_{x}$ levels via atmospheric dilution and chemical reactions, resulting in increased $\mathrm{O}_{3}$ production (e.g. Jost et al., 2003; Trentmann et al., 2003; Yokelson et al., 2003; Mason et al., 2006; Singh et al., 2012). During fire episodes, $\mathrm{O}_{3}$ levels may reach hazardous values, with the $8 \mathrm{~h}$ average $\mathrm{O}_{3}$ concentration often exceeding air quality standards (around 50-75 ppbv; Bytnerowicz et al., 2010). Fires also release huge amounts of both coarse- and finemode aerosols, leading to concentrations that largely exceed background levels (Phuleria et al., 2005; Hu et al., 2008) and that substantially affect visibility (Val Martin et al., 2015). Over Singapore, Indonesian fires caused the average daily minimum horizontal visibility to decrease, firstly, to less than $2 \mathrm{~km}$, and later to $500 \mathrm{~m}$ (Goldammer et al., 2009). Fire emissions encompass aerosol precursors such as $\mathrm{NH}_{3}$ and BVOCs as well.

\section{Forest management}

Forest management mainly relies on tree species selection, fertilization, litter raking, thinning, and clear-cutting (Eriksson et al., 2007), together with planting and harvest types, burning, and understory treatment.

From a physical perspective, along with crop management, forest management could have a similar impact on local cli- 
mate but is still poorly investigated (Bellassen and Luyssaert, 2014; Luyssaert et al., 2014), although forested areas cover one-third of the global land surface (Klein Goldewijk, 2001). The large conversion of broadleaved to managed conifer forest resulted in biogeophysical changes, which contributed to higher temperatures instead of attenuating them.

From a biological perspective, through modelling, Naudts et al. (2016) showed that 2.5 centuries of forest management in Europe may not have mitigated climate warming, contrary to what was sometimes assumed until now. With regard to atmospheric carbon budget, forests were altered from acting as a carbon sink to a carbon source because of the removal of litter, dead wood, and soil carbon pools.

From a chemical perspective, by modifying the surface characteristics, forest management can change sources and sinks of reactive compounds, and therefore affect air quality. Conversely, forest management can also be a tool when targeting air pollution reduction. Using a coupled-model approach, Baumgardner et al. (2012) analysed the improvement of air quality by a forested peri-urban national park in the Mexico City megalopolis and underlined that their results can be used to understand the air quality regulation potentially provided by peri-urban forests as an ecosystem service, together with the regional dynamics of air pollution emissions from major urban areas.

\subsection{Synthesis of current knowledge}

In the context of LULCCs and LMCs, the importance of land-atmosphere interactions for climate and air quality has been analysed in many studies published over the past 2-3 decades, exploring a large range of scales. We summarize here the current state of knowledge emerging from the articles we reviewed. For each of the LULCC categories (land cover change, agricultural intensification, urbanization) considered in this article, the direct and cascading effects on the physical, biological, and chemical processes are synthesized in Table 2.

Regarding physical processes, the works published so far on deforestation and afforestation mainly apply a modelling approach where the different processes involved (surface albedo, radiation, energy budget, etc.) are overall well understood. These works compare the effects between current and pre-industrial (potential) vegetation, representative of a time period with few (no) human activities. There is no single/simple response to these LULCCs as the sign and amplitude of the effects on temperature and precipitation depend on the latitude, on the pre-/post-vegetation types, and the landscape configuration. The effect on air temperature remains mainly unclear in most temperate regions, as this is where changes in the radiative budget compete with changes in the hydrological cycle. Regarding wetland drainage for agricultural purposes, very few studies investigate its impact on local and regional climate, in spite of the size of the areas affected. Via a modelling approach, existing studies show contrasting effects of wetland drainage on daily temperatures. Among agricultural management practices, irrigation is largely used all over the world and its impact on climate has been discussed in several studies using both observations and modelling. These works analyse both the greenhouse and the transpiration effect of irrigation, and suggest that the local cooling of irrigation might have partly masked the 20 th century climate warming at regional scales. The potential impacts on local to regional climate of other agricultural management practices, such as field preparation for planting, charcoal use for soil enrichment, or forest management, remain poorly investigated but existing studies suggest their impacts on specific seasons and on climate extremes may be significant. UHI effect on climate is largely analysed in the literature, and the reasons for a warmer climate are explained by a change in the surface radiative budget, a less efficient energy dissipation due to less convection, and heat release by human activities. However, the overall impact significantly varies depending on the time of the day, season, human activities, geographical location, and spatial organization of the urban fabric. Moreover, almost no studies refer to realistic landscapes and realistic changes, with potential compensation or amplifying effects. This is a challenge ahead as existing studies may not yet provide enough information to anticipate the impacts of realistic land use scenarios.

Whatever the land change described above, there is much numerical evidence that its effect on extreme weather/climate events is quite larger than its impact on mean seasonal or annual climate.

Focusing on central France, for example, Stéfanon et al. (2014) demonstrated that if this part of France had been partially afforested in 2003, the June heatwave would have been aggravated by up to $+3{ }^{\circ} \mathrm{C}$, while the August one would have been dampened by as much as $-1.6^{\circ} \mathrm{C}$ locally.

Enhanced extreme winter cold temperatures and lengthening of frosts have also been identified by Marshall et al. (2004a) in response to the drainage of wetlands and replacement by agriculture in Florida. By altering extreme conditions rather than the mean regional climate, these LULCCs have been responsible for reduced crop yields in the region.

Pitman et al. (2012a) carefully carried out a multi-model analysis at the global scale of the impacts of historical land cover changes on extreme temperature and precipitation indices (using the indices recommended by the CCl/CLIVAR/JCOMM Expert Team on Climate Change Detection and Indices, ETCCDI, based on daily maximum and minimum temperature and daily precipitation). They found that wherever the land cover change induced a decrease (increases) in averaged temperature, the extreme temperatures were also reduced (increased). By comparing the LULCCinduced changes to those resulting from the increase in atmospheric $\mathrm{CO}_{2}$ and sea-surface temperatures during the same historical period, the authors found that the LULCC-induced changes may be as large as changes triggered by global 
Table 2. Synthesis of direct and indirect effects of land use and land cover changes as well as land management changes as seen from a physical, biological, or chemical perspective.

\begin{tabular}{|c|c|c|c|c|c|}
\hline & $\begin{array}{l}\text { Process } \\
\text { involved }\end{array}$ & $\begin{array}{l}\text { Some affected variables/ } \\
\text { fluxes }\end{array}$ & Direct effect & Cascading effect & $\begin{array}{l}\text { Scale } \\
\text { concerned }\end{array}$ \\
\hline \multirow[t]{3}{*}{$\begin{array}{l}\text { Land use in- } \\
\text { tensification }\end{array}$} & Physical & $\begin{array}{l}\text { Albedo; roughness length/ } \\
\text { sensible and latent heat } \\
\text { fluxes }\end{array}$ & $\begin{array}{l}\text { Change in atmospheric } \\
\text { momentum heat and wa- } \\
\text { ter content }\end{array}$ & $\begin{array}{l}\text { Temperature; wind circu- } \\
\text { lation; precipitation and } \\
\text { cloud cover through con- } \\
\text { vection processes }\end{array}$ & $\begin{array}{l}\text { Global, } \\
\text { regional, } \\
\text { local }\end{array}$ \\
\hline & Biological & $\begin{array}{l}\text { Photosynthesis rate; stom- } \\
\text { atal functioning; soil func- } \\
\text { tioning (mineralization) }\end{array}$ & $\begin{array}{l}\text { Change in atmospheric } \\
\text { concentrations of GHG, } \\
\text { non-GHG, aerosols; and } \\
\text { water content }\end{array}$ & $\begin{array}{l}\text { Temperature; convection; } \\
\text { cloudiness }\end{array}$ & $\begin{array}{l}\text { Global, } \\
\text { regional, } \\
\text { local }\end{array}$ \\
\hline & Chemical & $\begin{array}{l}\text { Ecosystem emission ca- } \\
\text { pacity, leaf area, deposi- } \\
\text { tion efficiency on surfaces }\end{array}$ & $\begin{array}{l}\text { Change in net emission } \\
\text { fluxes of chemical com- } \\
\text { pounds to the atmosphere } \\
\text { (VOCs) }\end{array}$ & $\begin{array}{l}\text { Changes in atmospheric } \\
\text { chemical composition } \\
\left(\mathrm{O}_{3} \text {, VOCs, concen- }\right. \\
\text { trations, and reactions } \\
\text { involved, aerosols })\end{array}$ & $\begin{array}{l}\text { Global, } \\
\text { regional, } \\
\text { local }\end{array}$ \\
\hline \multirow[t]{3}{*}{$\begin{array}{l}\text { Agricultural } \\
\text { intensifica- } \\
\text { tion }\end{array}$} & Physical & $\begin{array}{l}\text { Sensible and latent heat } \\
\text { fluxes; albedo; roughness } \\
\text { length }\end{array}$ & $\begin{array}{l}\text { Change in atmospheric } \\
\text { momentum, heat, and } \\
\text { water content }\end{array}$ & $\begin{array}{l}\text { Temperature; wind circu- } \\
\text { lation; precipitation and } \\
\text { cloud cover through con- } \\
\text { vection processes }\end{array}$ & $\begin{array}{l}\text { Global, } \\
\text { regional, } \\
\text { local }\end{array}$ \\
\hline & Biological & $\begin{array}{l}\text { Change in photosynthesis; } \\
\text { change in productivity }\end{array}$ & $\begin{array}{l}\text { Change in GHG emis- } \\
\text { sions }\end{array}$ & $\begin{array}{l}\text { Change in net emissions } \\
\text { of chemical compounds } \\
\left(\mathrm{NH}_{3}, \mathrm{BVOCs}\right) \text {, change in } \\
\text { water and energy budgets }\end{array}$ & $\begin{array}{l}\text { Regional, } \\
\text { local }\end{array}$ \\
\hline & Chemical & Change in $\mathrm{N}$ input & $\begin{array}{l}\text { Change in emissions of } \\
\mathrm{N} \text { compounds from soils } \\
\left(\mathrm{NO}_{x} \text { and } \mathrm{NH}_{3} \text { for in- }\right. \\
\text { stance })\end{array}$ & $\begin{array}{l}\text { Impact on primary and } \\
\text { secondary aerosol forma- } \\
\text { tion }\end{array}$ & $\begin{array}{l}\text { Regional, } \\
\text { local }\end{array}$ \\
\hline \multirow[t]{3}{*}{$\begin{array}{l}\text { Urban inten- } \\
\text { sification }\end{array}$} & Physical & $\begin{array}{l}\text { Sensible and latent heat } \\
\text { fluxes; albedo; roughness } \\
\text { length }\end{array}$ & $\begin{array}{l}\text { Change in atmospheric } \\
\text { momentum, heat, and } \\
\text { water content }\end{array}$ & $\begin{array}{l}\text { Temperature; wind circu- } \\
\text { lation; precipitation and } \\
\text { cloud cover through con- } \\
\text { vection processes }\end{array}$ & $\begin{array}{l}\text { Global, } \\
\text { regional, } \\
\text { local }\end{array}$ \\
\hline & Biological & Change in biodiversity & $\begin{array}{l}\text { Change in photosynthe- } \\
\text { sis and productivity }\end{array}$ & $\begin{array}{l}\text { Change in plant phenol- } \\
\text { ogy due to the tempera- } \\
\text { ture and water availability }\end{array}$ & $\begin{array}{l}\text { Regional, } \\
\text { local }\end{array}$ \\
\hline & Chemical & $\begin{array}{l}\text { Emission sources of chem- } \\
\text { ical compounds into the } \\
\text { atmosphere (amount and } \\
\text { composition), deposition } \\
\text { efficiency on surfaces }\end{array}$ & $\begin{array}{l}\text { Change in atmospheric } \\
\text { chemical composition, } \\
\text { occurrence of pollution } \\
\text { episodes, increase in } \\
\text { background pollution }\end{array}$ & $\begin{array}{l}\text { Natural and agricultural } \\
\text { ecosystem productivity } \\
\text { affected by impacts on } \\
\text { ecosystem functioning } \\
\text { and stomatal closure }\end{array}$ & $\begin{array}{l}\text { Regional, } \\
\text { local }\end{array}$ \\
\hline
\end{tabular}

warming, sometimes even larger, and potentially of opposite sign.

Any land cover conversion or land management that favours the increase in (or reversely the decrease in) evapotranspiration during a specific season (e.g. irrigation, crop intensification versus deforestation, tillage suppression) has consequences on extreme daily temperatures, without affecting the mean seasonal temperatures. LULCCs and LMCs generally reduce maximum temperatures $\left(T_{\max }\right)$ and thereby reduce the diurnal thermal amplitude (Davin et al., 2014; Thiery et al., 2017).

Focusing on biological processes, several studies show that, via changes in temperature and soil moisture, deforestation affects nutrient mineralization in soils by enhancing carbon and nitrogen release to the atmosphere and the environment. Some of the released gases have a significant warming potential $\left(\mathrm{CO}_{2}, \mathrm{CH}_{4}, \mathrm{~N}_{2} \mathrm{O}\right.$, for instance) or they are involved in the ozone cycle or aerosol formation (e.g. emissions from 
fire clearing). These compounds can affect the climate at local, regional, or global scales. Several studies show that peatland and wetland conversion affect climate from the local, through evaporation and surface temperature change, to the global scale, by changing surface emissions of greenhouse gases such as $\mathrm{CO}_{2}$ or $\mathrm{CH}_{4}$. Impacts of agricultural management on climate and air quality are widely investigated via modelling or experimental studies at the local scale; however, very few studies investigate the impact of agricultural management on climate through changes in biological processes at the landscape, regional, or global scales. Land use intensification and fertilization are shown to have the potential to affect climate, through modification of greenhouse gas emissions and carbon sequestration, but also on regional air quality via the emission of different reactive species such as $\mathrm{NH}_{3}$, $\mathrm{NO}_{x}$, and several VOC species. This highlights the complex interactions and feedbacks between chemistry and biology, such as the interactions between ozone and reactive nitrogen in the context of their mutual impacts on ecosystems. Key results showed that exposure to ambient $\mathrm{O}_{3}$ concentrations was reducing the nitrogen use efficiency of plants, both decreasing agricultural production and posing an increased risk of other forms of nitrogen pollution, such as nitrate leaching $\left(\mathrm{NO}_{3}\right)$. Ambient levels of aerosols were also demonstrated to reduce the ability of plants to conserve water under drought conditions. These results clearly show the tight interactions between the atmospheric chemical composition and the ecosystem and agroecosystem functioning, with a strong need for further model adaptation and investigations.

At last, by affecting surface emissions and atmospheric chemical processes, LULCCs and LMCs have the potential to affect air quality, by changing air pollutant concentrations, and the local-to-global climate, by modifying greenhouse gases $\left(\mathrm{O}_{3}, \mathrm{CH}_{4}, \mathrm{CO}_{2}\right.$, etc.) or levels of radiative compounds (e.g. aerosols). Most of the studies published so far apply a modelling approach and analyse the impact of regional- or large-scale changes in land cover on land-atmosphere chemical interactions (deforestation in tropical areas, preindustrial to present day or future changes in vegetation distribution, etc.). The increase in biofuel and oil palm plantations for energy and food production has been targeted by several studies. Among the different agricultural practices, fertilization, agriculture fires, and fallow periods have been shown to affect air quality by emitting ammonia, ozone precursors, and/or aerosols. However, the impact of land and agricultural management on air quality, and potentially climate, through changes in land-atmosphere chemical interactions, remains poorly investigated. An increasing number of studies assessed the impact of urbanization on land-atmosphere chemical interactions and air quality, with an increasing interest in the impact of urban trees on ozone pollution, through changes in BVOC emissions.

\section{Interactions between different land cover, uses, and managements over a mosaic landscape: impacts on land surface exchanges}

In the real world complexity arises where territories are composed of a mosaic of very diverse landscapes in which physical, biological, and chemical processes take place and interact altogether. Areas of agricultural surfaces, covered by different types of crops and cattle, forests composed of a varying mixture of plant types, and urban and peri-urban areas of different sizes co-exist next to each other, sharing one single atmosphere with no boundaries. Therefore, one homogeneous parcel has the potential to influence surrounding ones, over a range of time and geographic scales that will depend on considered processes, as illustrated in Fig. 4. Horizontal transport of air masses promotes water, heat, or pollutant exchanges between surrounding areas. Regarding air quality, compounds emitted from one area can be transported to remote places, depending on their lifetime, undergo chemical transformations in the atmosphere, and consequently influence the chemical composition of the air in distant regions. In this section, we will draw an overview of possible interactions between physical, biological, and chemical processes, and we will analyse them over a mosaic of landscapes from three different perspectives: local climate, air quality, and ecosystem functioning. These changes and interactions ultimately modify local climate and air pollution as specified in Sect. 3.

\subsection{Local to meso-climate perspective}

Horizontal advection from one LULC to another can significantly modify local climate downwind. For instance, urban areas not only heat their local environment but also their surroundings due to horizontal transport of warm air masses to suburban and rural environments. As reported by Bohnenstengel et al. (2011), suburban areas downwind of London are $1{ }^{\circ} \mathrm{C}$ warmer during night-time than upwind ones due to heat advected from the city centre. Similarly, Heaviside et al. (2015) found that temperatures downwind of Birmingham were up to $2.5^{\circ} \mathrm{C}$ warmer than those upwind during the heatwave of August 2003. Sarrat et al. (2006) found that temperatures in suburban areas were $1.5^{\circ} \mathrm{C}$ warmer when including the UHI effect in their simulation than without considering it. They also highlighted that UHI is displaced to suburban areas by horizontal advection and forms an urban heat plume. This effect can extend to about tens of kilometres downwind (Brandsma et al., 2003; Bohnenstengel et al., 2011). However, this issue is closely linked with wind speed (Kim and Baik, 2002; Brandsma et al., 2003): a minimum wind speed $\left(>0.1 \mathrm{~m} \mathrm{~s}^{-1}\right)$ is required for urban heat advection to become effective, while for larger wind speeds $\left(>5 \mathrm{~m} \mathrm{~s}^{-1}\right)$ the mixing of the heat plume with the overlying atmosphere decreases this effect (Brandsma et al., 2003). 


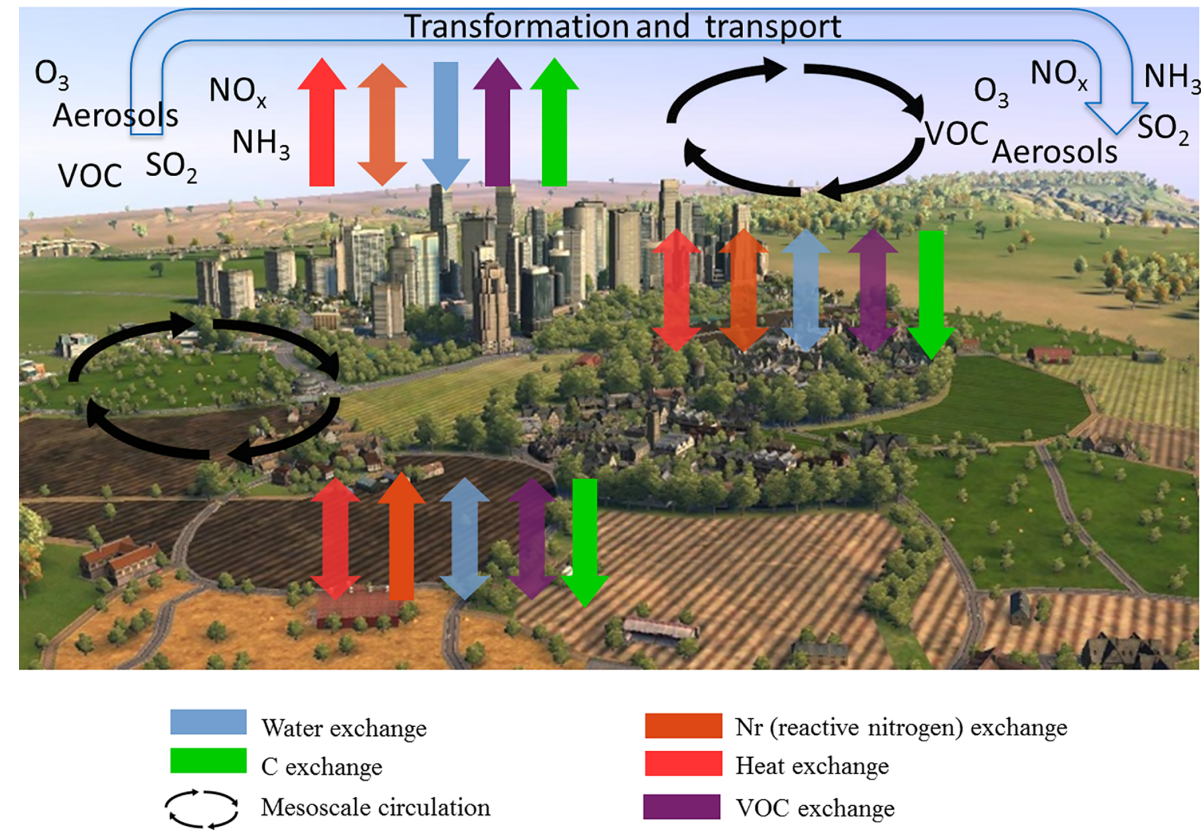

Figure 4. Interactions between different land uses and major trend of gaseous flux direction from each land use type. Different colours represent different scalars. Monodirectional arrows indicate where scalars are mostly emitted or deposited by the land use. Bidirectional arrows indicate where scalars can be emitted or deposited depending on atmospheric and ecosystem conditions.

Moreover, spatial heterogeneities induced by LULCCs are likely to produce atmospheric circulations - similar to the sea/lake breeze (so-called non-classical mesoscale circulations) - or to modify the magnitude of pre-existing background wind, as documented experimentally (Briggs, 1988; Mahrt et al., 1994) as well as numerically (Mahfouf et al., 1987; Hadfield et al., 1992; Shen and Leclerc, 1995; Avissar and Schmidt, 1998; Stohlgren et al., 1998). Heterogeneities of surface properties and heat fluxes over contrasting areas are the main and required criteria for this mesoscale process (Anthes, 1984; Segal et al., 1988) that can generate over bare soil-vegetated areas, irrigated-unirrigated regions, urban-rural areas, or mountain-valley structures (Avissar and Pielke, 1989). Distribution of heating at scales of the order of tens of kilometres is necessary to initiate such circulations (André et al., 1990; Mahrt and Ek, 1993; Segal and Arrit, 1992; Wang et al., 2000). The generation of mesoscale circulations carries heat and water vapour, which have a significant influence on the planetary boundary layer dynamics and properties (temperature, water vapour, cloudiness, and vertical heat flux) (Anthes, 1984; Segal et al., 1988; Avissar and Liu, 1996; Avissar and Schmidt, 1998). For instance, deforestation upwind of montane forests results in warmer and drier air, which induces thinner clouds and a reduction in air humidity (Nair et al., 2003; Ray et al., 2006). Conversely, downwind of heavily irrigated areas, a rainfall increase of $15 \%-30 \%$ was observed over the US Great Plains (DeAngelis et al., 2010). Finally, although it is clear urban areas alter rainfall events in their surroundings (Shepherd,
2005), it is difficult to precisely assess the localization and magnitude of induced rainfall events. For instance, Shepherd et al. (2002) reported that the maximum rainfall rates were between $48 \%$ and $116 \%$ larger downwind of the city than upwind, while Dou et al. (2015) found that minimum rainfall occurred directly downwind of the urban area (up to $-35 \%$ ), whereas the maximum values occurred along its downwind lateral edges.

\subsection{Ecosystem functioning perspective}

It has long been acknowledged that simultaneous interactions exist between landscape organization, structure, and biological functioning. Human activity also plays a major role in regulating and shaping those dynamic biogeophysical interactions at the landscape level. Organisms not only respond to their physical environment, but they also directly modify and control their physical environment in ways that promote their own persistence. Several scientific disciplines such as "ecological stoichiometry" (Sterner et al., 2017), "ecosystem engineering" (Jones et al., 1994), and "biodiversity and ecosystem functioning" (Loreau et al., 2002) illustrate how living organisms shape their own environment through biogeochemical alteration in a multidimensional environment. These different interactions between animals, vegetation and physical and chemical processes can be illustrated through different examples such as alteration of soils and water quality, seed and spore dispersal, and competition for soil, moisture, and light (Hastings, 2004). 
There are several examples in non-anthropized environments, which show the feedbacks between macrofauna, vegetation, soil formation, sediment transport, and ultimately landscape formation. For example, Van Hulzen et al. (2007) demonstrated how certain plant species both modify their habitat via their own physical structures and respond to those modifications. The plant modifies its environment so that it becomes more locally favourable. However, these modifications create small "islands", therefore limiting the plant from spreading. There is a consensus that climate-driven changes in precipitation will influence the pattern and vegetation type (and animals) in landscapes, which will in turn influence physical processes. However, today, human activity mainly shapes the landscape we live in. For example, high inputs of fertilizers and pesticides degrade the habitat quality, while the expansion of arable lands promotes widespread landscape homogenization (Robinson and Sutherland, 2002). Studies over the last 2 decades have emphasized the importance of landscape-scale effects in these processes (Benton et al., 2003; Hole et al., 2005; Matson et al., 1997; Swift et al., 2004; Vandermeer et al., 1998).

Biological processes respond differently based on landscape structure. For example, Vinatier et al. (2012) showed that pest dispersal may be of greater importance in fragmented rather than homogenous landscapes. By considering the link between ecological processes and landscape composition, one can therefore evaluate the impact of habitat loss and fragmentation due to human activity on different population dynamics (Wiegand et al., 2000, 2005; Fahrig, 2003). In this context, some results are sometimes contradictory. Roschewitz et al. (2005) and Thies et al. (2005) found that complex landscapes, characterized by a higher proportion of semi-natural habitats, increase aphid parasitism rate but also aphid abundances. Conversely, studies by Caballero-López et al. (2012), Costamagna et al. (2004), Menalled et al. (2003), and Vollhardt et al. (2008) showed that landscape complexity has no effect on parasite diversity.

Another critical issue linked to ecosystem functioning and landscape structure is soil quality. Montgomery (2007) showed that conventionally ploughed fields generally erode at rates typical of alpine terrain under native vegetation. However, LULCCs are not only the cause but can also be the consequence of erosion processes (Bakker et al., 2005). Landscape alteration also influences nitrogen availability through its impact on organic matter through fire (Mataix-Solera et al., 2011; Debano and Conrad, 1978), tree fall (Schroth et al., 2002; Mladenoff, 1987; Vitousek and Denslow, 1986; Muscolo et al., 2014; Feldpausch et al., 2011), and forest practice (Fujisaki et al., 2015; Guimarães et al., 2013; Berenguer et al., 2014; Bormann and Likens, 1979; Vitousek and Matson, 1985), which all produce patchy landscapes. Soil nitrogen alterations can have important immediate consequences for $\mathrm{N}$ cycling as volatilization, recycling of organic matter from aboveground biomass, reduced uptake by plants, altered rates of solution transport through the soil profile, and elevated mineralization. These disturbances can indirectly affect the ways in which different species colonize disturbed areas and recycle N. Over longer periods, the species composition resulting from disturbance might affect nutrient supply and influence total carbon and $\mathrm{N}$ pools, element ratios, and pH (Zinke, 1962; Wagle and Kitchen, 1972; Christensen and Muller, 1975; Christensen, 1977; Raison, 1979; Boerner, 1982).

Proximity of a natural ecosystem to an urban area also alters this ecosystem functioning as it has been shown through several studies. As mentioned above, air quality and more precisely ozone concentrations affect leaf photosynthesis and therefore ecosystem production. The degradation of ecosystems in proximity with big cities has been studied mainly in the perspective of analysing the effect on ecosystem services and the subsequent effects on populations in general and vulnerable populations in particular (Elmqvist, 2013; Haase et al., 2014).

\subsection{Air quality perspective}

As illustrated in Sect. 3, LULCCs and LMCs directly influence the local air pollution via changes in the intensity and variability (temporal and geographical) of chemical emissions (e.g. BVOCs from tree species, $\mathrm{NO}_{x}$ emissions from soils and fertilization) or in chemical processes and regimes (e.g. from $\mathrm{NO}_{x}$ - to $\mathrm{VOC}$-sensitive regimes in $\mathrm{O}_{3}$ production). In addition, by modifying land-atmosphere interactions, LULCCs and LMCs can indirectly affect air quality by altering atmospheric circulation (i.e. vertical mixing and advection) with consequences for the dispersion of pollutants and of pollutant precursors.

Pollutant dispersion in the planetary boundary layer (PBL) is strongly influenced by changes in the PBL height and in convective transport, which are triggered in turn by modified land-atmosphere energy transfer (Ganzeveld and Lelieveld, 2004; Civerolo et al., 2007; Rendón et al., 2014; Wagner and Schäfer, 2017). Intense convection makes the PBL deeper; this condition, together with enhanced advection, increases pollutant dispersion. In the troposphere, $\mathrm{O}_{3}$ and secondary aerosol production depends on the abundance of their precursors (i.e. $\mathrm{NO}_{x}$ and VOCs). Increased dispersion may reduce concentrations of precursors, finally reducing ozone production. Conversely, stagnant atmospheric conditions often associated with low advection and strong thermal inversion, limit pollutant dispersion and favour $\mathrm{O}_{3}$ production.

Stagnant atmospheric conditions correspond to low winds, intense solar radiation, and high surface temperatures. Under these sunny and warm conditions, $\mathrm{O}_{3}$ production increases because of the direct effect of altered radical production and photochemistry (Fiore et al., 2012) and the indirect effect of enhanced BVOC emissions (e.g. Cardelino and Chameides, 1990; Taha, 1996; Val Martin et al., 2015). At the urban scale, Cardelino and Chameides (1990) estimated a rise of $25 \%$ in BVOC emissions due to warmer temperatures, in 
spite of a decrease in forest areas by $20 \%$, due to growing urbanization. In terms of $\mathrm{O}_{3}$ production, increased BVOC emissions ruled out the benefits of a substantial reduction in anthropogenic VOC emissions $(-50 \%)$ via "clean air" policies. Enhanced BVOC emissions may also feed the aerosol loading via BSOA production (e.g. Cardelino and Chameides, 1990; Nowak et al., 2000). The influence of atmospheric conditions on the aerosol loading depends on the aerosol type. Nitrates dominate under cold temperatures, while sulfates prefer warm temperatures. Hygroscopic aerosols benefit from high humidity. For most aerosols, the precipitation rate directly controls the aerosol loading since scavenging (wet deposition) is the main sink for aerosols.

Surface roughness and vegetation conditions (i.e. plant type, plant health, heat stress) strongly affect both aerosol and $\mathrm{O}_{3}$ dry deposition. Ozone deposition involves biological processes and decreases with decreasing surface and leaf wetness (Klemm and Mangold, 2001). When vegetation is not water-limited, ozone can be absorbed by leaves via stomatal uptake. Above a certain threshold, $\mathrm{O}_{3}$ deposition reduces photosynthesis, plant growth, biomass accumulation, and crop yields, and affects stomatal control over plant evapotranspiration (Ainsworth et al., 2012). Hence, although $\mathrm{O}_{3}$ deposition by stomatal uptake improves air quality, it may result in plant damage in the long term. Ozone deposition also depends on mechanical processes. By increasing surface roughness, trees reduce horizontal wind speeds and limit pollutant dispersion, leading to increased ozone levels both locally and regionally (e.g. Nowak et al., 2000). Conversely, reforestation of croplands (Trail et al., 2015) or vegetation increase in urban areas (Taha, 1996) improves $\mathrm{O}_{3}$ deposition and reduces $\mathrm{O}_{3}$ concentration. This ozone-reducing mechanism combines with other afforestation-driven effects, such as reduced $\mathrm{NO}_{x}$ emissions from soils and fertilization and lower surface temperatures, and competes with higher BVOC emissions from trees, which may trigger $\mathrm{O}_{3}$ production (Trail et al., 2015). Ecosystem distribution can also be a significant driver of deposition efficiency, which is still not well quantified. A shift from croplands to grasslands reduces dry deposition velocity and increases ozone concentration (Val Martin et al., 2015). Taking into account the 2050 RCP 8.5 vegetation distribution, which is characterized by an expansion of land used for crops and pastures at the expense of forests, Verbeke et al. (2015) calculated a rise in the surface ozone deposition velocity, relative to the present-day values, up to $7 \%$ in tropical Africa and up to $+18 \%$ in Australia. Moreover, although pollutant deposition on trees significantly reduces ozone levels, this effect is hampered as the PBL height increases (Nowak et al., 2000). Conversely, a conversion from forests to croplands modifies stomatal activity and affects deposition rates of trace gases, such as ozone, more than changes in leaf area index (LAI; Trail et al., 2015). Furthermore, for aerosols, conversion from forests to croplands reduces aerosol dry deposition because of decreased surface roughness. In cities, promoting green infrastructures has been considered a tool to improve air quality, but their actual impact on the atmospheric chemical composition is only quantified in a few studies (Churkina et al., 2017; Ren et al., 2017). A recent review by Abhijith et al. (2017) shows that the choice of infrastructure is critical, with, for instance, low-level green infrastructure (hedges) improving air quality compared to high vegetation canopies.

To summarize, LULCCs and LMCs affect air quality directly, by influencing the sources and sinks of reactive compounds at the surface, and indirectly, by modifying environmental conditions (temperature, mixing) in which surfaceatmosphere chemical exchanges occur. By modifying the air chemical composition and possibly affecting the occurrence of pollution episodes, changes described so far have the potential to affect, in turn, vegetation distribution and growth. Consequently, these changes could also retroactively affect physical and biological processes involved, with potential impact on meteorological conditions and climate, at the local and regional scales. To investigate future air quality, future LULCCs and LMCs should be accounted for in meteorological models that provide forcing to chemical-transport models. If not, projections of future air quality will not account for the indirect influence of land-atmosphere interactions on the evolution of air quality (Civerolo et al., 2000).

\section{Future research}

In Sect. 3 we have reviewed recent progress, from both an experimental and modelling point of view, in our understanding of processes and mechanisms involved in land-atmosphere interactions at different scales, going from organ to plant, from plot up to regional scales. In Sect. 4 we have discussed studies focusing on the interactions between the different landscape structures that affect local climate and air quality. Through these analyses, we have highlighted that the representation of interactions and feedbacks between the different compartments (physics, biology, chemistry) and surfaces (urban, peri-urban, agricultural, natural, etc.) is crucial when investigating the impact of LULCCs on climate from small to larger scales. Based on these analyses, in the present section we identify actual knowledge gaps in the processes, feedbacks, methodologies, and parameterizations currently used to reproduce interactions between land, LULCCs, and the atmosphere. Below we summarize the limitations that exist today and that restrain our capacity to investigate the effects of LULCCs and LMCs on local climate and air quality at different scales using a modelling and/or an experimental approach, while considering all the interactions involved.

\subsection{Challenges ahead}

The first challenge is the lack of integration between the different known processes. It is not easy to design an experimental protocol that allows us to differentiate between 
the impacts relative to each different process (Pitman et al., 2012b). Although several initiatives are being conducted to couple model and ecosystem based experiments to allow disentangling of processes and better model performance (ex. Norby et al., 2016; Medlyn et al., 2015), it is still a big challenge today (Higgins, 2017). Nearby urban areas, for example, strong pollution levels - with especially high ozone concentration - may directly affect plant productivity through atmospheric advection of those pollutants downwind from the city. In such a case, surface and air temperature may be perturbed in rural regions through changes in vegetation characteristics (e.g. stomatal opening, albedo) and fluxes (e.g. latent heat flux). A coupled land-atmosphere model that does not account for chemistry processes will therefore not be able to correctly reproduce surface climate and vegetation status in the rural environment. In addition, the representation of urban areas is often very simplified. For instance, regarding atmospheric chemistry, emission sources are usually prescribed, which do not allow us to account for feedbacks. Hence, a coupled urban-vegetation-chemistry model is a necessary development, as also pointed out by Baklanov et al. (2014) in their review of online modelling of atmospheric and chemical conditions (i.e. online modelling refers to the numerical technique of having atmospheric and chemical conditions evolve in parallel with the atmospheric and the chemical modules exchanging information in the two ways at each time step).

Figure 5a illustrates the interactions between the different variables and processes involved in biosphere-atmosphere exchanges as discussed in the previous sections (that are not exhaustive with respect to the existing literature). Today most of these interactions (solid lines) are relatively well known but are not yet experimentally measured or jointly accounted for in regional global climate models, which we are targeting here. Whereas global climate models, such as those used for the Coupled Model Intercomparison Project (CMIP) exercises for the Intergovernmental Panel on Climate Change (IPCC), are now referred to as Earth system models (ESMs) that include a large spectrum of physical, chemical, and biological processes in the modules that describe the atmosphere, biosphere, and hydrosphere reservoirs, regional climate models have recently started to move towards the frontiers of regional ESMs (e.g. Sitz et al., 2017).

The second challenge relies on the detailed representation of the variety of surfaces in the above-mentioned models. Indeed, surfaces such as cities, managed forests, mixed areas, wetlands, or the variety of agricultural crops are oversimplified (e.g. no distinction of forest species in a forest biome), misrepresented (e.g. crops represented as a super-grassland), or absent (e.g. absence of wetland representation). Such gaps could be potentially bridged by using more sophisticated dynamic global vegetation models (DGVMs) than those currently used in climate models. In their analysis of DGVMs, Scheiter et al. (2013) pinpointed some of the limits of the current generation of DGVMs such as, for instance, the use of bioclimatic limits to force the modelled vegetation type to grow under the "correct climate" (the one that will guarantee the selected vegetation type to grow), or the parametrization of the number of species and the degree of functional diversity that is necessary to sustain ecosystem function. The authors tested, in a trait- and individual-based vegetation model, some of the new concepts that could fit in the next generation of DGVMs (e.g. assembly theory) and coexistence theory. Moreover, DGVMs could be coupled to chemistry models to gain a better description of the land surface as well as of the land management practice If such DGVMs may include the impact changes in air quality have on the functioning of the ecosystems they model, the reverse is not true. Most chemistry and transport models, for example, consider prescribed and fixed information for vegetation (distribution, areas, related characteristics such as leaf area index, stomatal resistance, etc.) and as well for land management and farming practices, which are relatively scarce at the regional and global scales. As this information is used to calculate emissions and deposition, it can strongly affect the assessment of atmospheric chemical composition. Therefore, the numerical coupling between atmospheric chemistry and the terrestrial biosphere, or at least a more dynamic representation of vegetation in chemistry-transport models (Baklanov et al., 2014), is a crucial step forward in the development of integrated numerical tools. Coarse-resolution models (e.g. global scale, $\sim 100 \mathrm{~km}$ ) may be inadequate in separating different chemical regimes that are triggered by emission patterns of biogenic and anthropogenic sources. However, today, the integration of such loops in numerical models is limited because the various components of these interactions are developed by independent groups, in diverse surface models that are not all coupled to atmospheric models. This is of high importance, especially in short- or long-term conditions where LULCCs and climate are meant to change significantly under the influence of human activities. For instance, the variety of plant species encompassed in a BVOC emission database is limited (e.g. Ashworth et al., 2012), with therefore incomplete information regarding emission geographical variability. This biases both the ability to describe and to properly evaluate BVOC emissions in modelling tools. Green roofs in urban-atmosphere models are generally represented through uniform, idealized vegetation, while ecological papers have shown a large variability in the vegetation response to climate, depending on species. Not accounting for such biodiversity may affect the ability to calculate the exact cooling effect of those roofs. Moreover, studies often target emissions from a single sector (e.g. oil palm industry, biofuel production) without taking into account emission evolution in other sectors (other than oil crop/biofuel industry) or in nearby regions (e.g. Hewitt et al., 2009). The exclusion of emission sources other than those from LULCCs and LMCs may affect results (over- or underestimate) regarding ozone and aerosol levels. For example, most large-scale modelling studies use global vegetation models to investigate the inter- 


\section{(a) VARIABLES and PROCESSES}

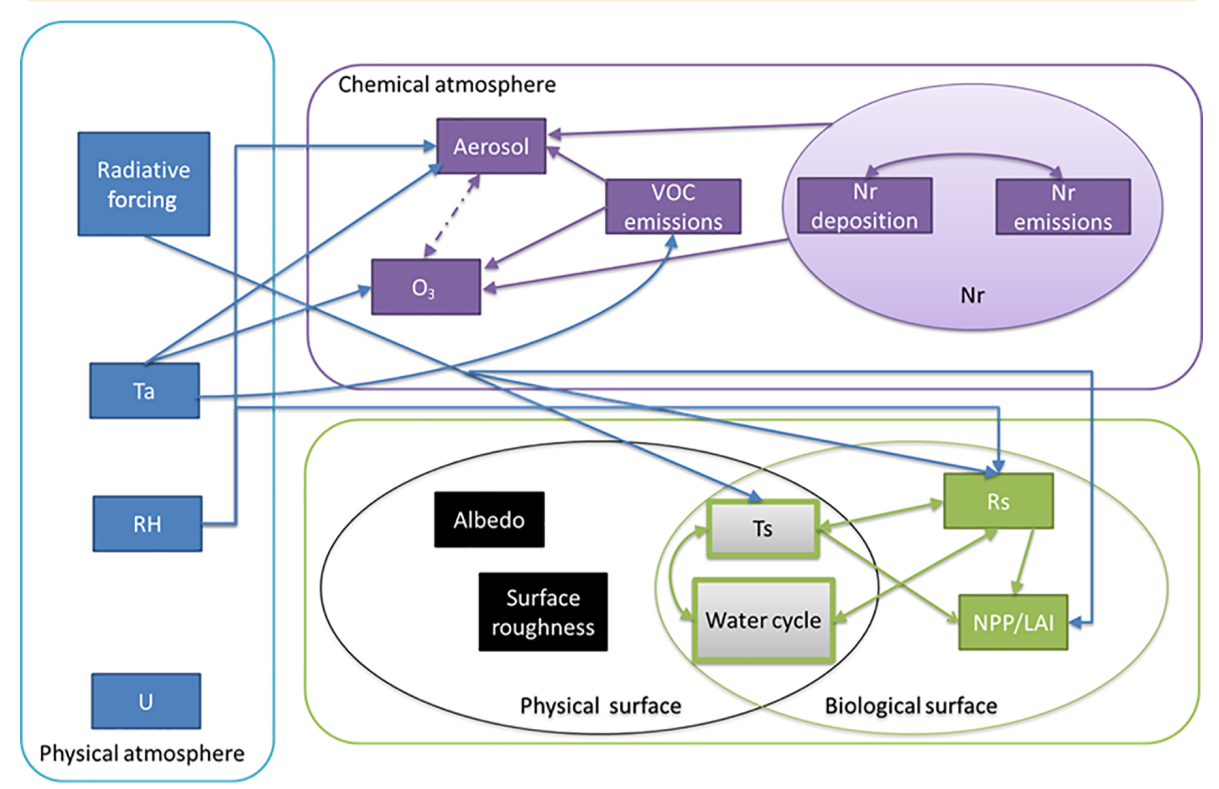

(b) FEEDBACKS

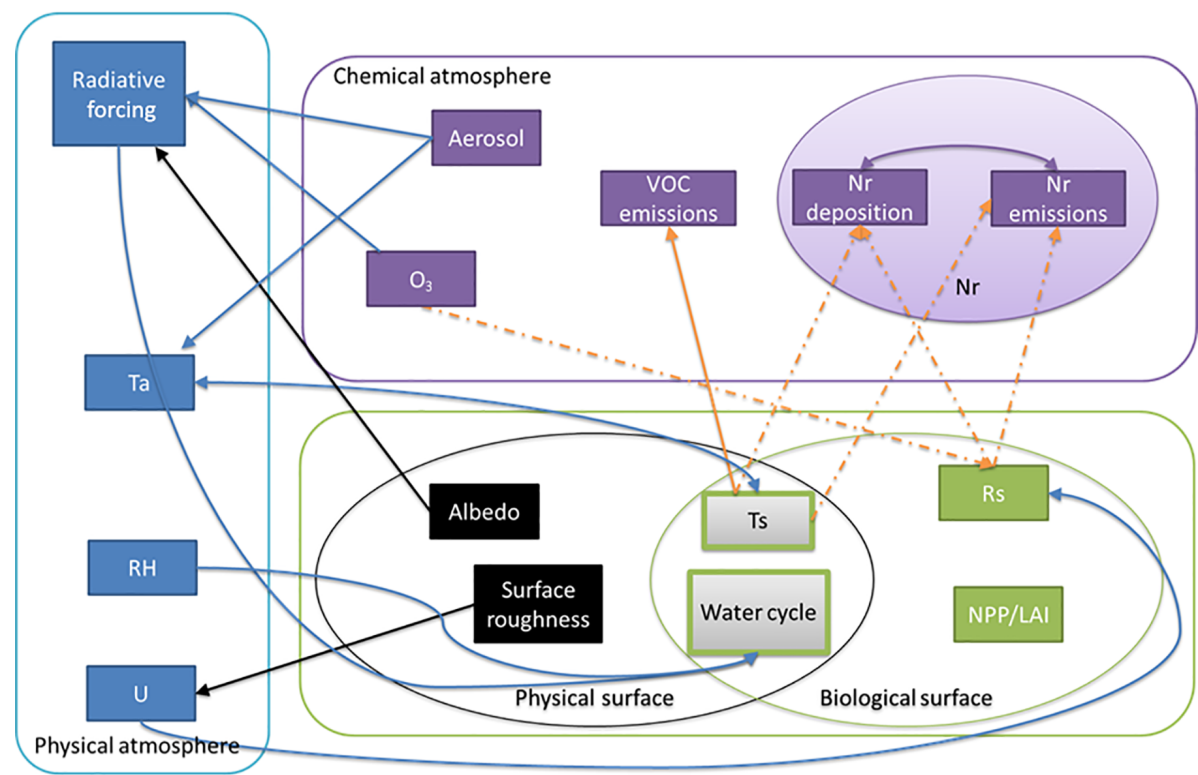

Figure 5. Interactions between the different variables and processes (a) concerned in biosphere-atmosphere exchanges as well as feedbacks (b) involved between the physical and biological surfaces of an ecosystem and the physical and chemical compartments of the adjacent atmosphere. Full arrows represent well-documented processes and feedbacks; dashed arrows represent mechanisms having knowledge gaps or badly represented in most models. $N_{\mathrm{r}}$ stands for reactive nitrogen species, $T_{\mathrm{a}}$ for air temperature, RH for air relative humidity, $U$ for average wind speed, VOC for volatile organic compounds, $T_{\mathrm{S}}$ for surface temperature, $R_{\mathrm{S}}$ for stomatal resistance, net primary production (NPP) for net primary production, and LAI for leaf area index. This schematic covers most atmospheric variables discussed in the paper, but not all atmospheric variables that can be affected. Rainfall and cloudiness for example are amongst the ones that have been shown to be sensitive to land and are not discussed herein. 
actions between the chemistry and the biosphere and adopt a simplified representation of ecosystems as a selection of plant functional types (PFTs). The PFT approach lumps individual plants with similar ecological characteristics and behaviours under the same vegetation type. Although the PFT approach works at the global scale, once applied at the regional scale it may restrain the model skills in representing the ecosystem variability as well as the land management scenarios, which are often not accounted for in the models, as also pointed out by Scheiter et al. (2013).

The third challenge is the need for observational data covering more temporal and spatial scales. For example, various observations of BVOC or reactive $\mathrm{N}$ compound emissions have been published for European and North American ecosystems, while few observational studies target southern regions. Due to the absence of such a dataset, it is complicated to perform robust evaluation of models at the adapted scales, as also pointed out by Arneth et al. (2008). There is obviously a missing link between the regional scale, at which most chemistry and transport models are run, and local scales, where observations are collected. Such investigations could also help to improve parameterizations generally used in models. The dependency of certain processes on different plant species and pedo-climatic regions is indeed generally not well described in model parameterizations.

Lastly, some processes are known but are not yet implemented in models. Figure 5b represents the existing known feedbacks between the different compartments. The feedbacks between the biosphere and the atmosphere via the impacts of vegetation on chemistry (dashed lines) are an example of missing processes in the majority of models. For example, bidirectional exchange of reactive $\mathrm{N}$ compounds is well known today but few chemistry and transport models fully integrate $\mathrm{N}$ exchanges, although some advances have been made concerning ammonia (Bash et al., 2013; Zhu et al., 2015). However, we are still missing process-level knowledge on some of those interactions.

\subsection{Towards interdisciplinary approaches}

This review has highlighted the need to connect different scientific disciplines (e.g. physics, ecology, biology, agronomy, chemistry) in order to correctly represent the impacts of LULCCs and LMCs on climate at various spatial scales. In the following, we illustrate the need for such connections using two examples of current challenges in Europe.

\subsubsection{Urban - agricultural - natural triptych in a $\mathbf{N}$ pollution context}

While agriculture has been criticized for several decades for its impacts on water quality (nitrate and pesticides) and for its contribution to climate change (emissions of nitrous oxide and methane), the question of its contribution to air pollution in urban and peri-urban areas has emerged only re- cently in the public debate, with a particular resurgence in recent spring episodes of aerosol pollution. Ammonia, which is largely emitted by animal excreta and by the application of mineral and organic fertilizers, contributes to the formation of secondary aerosols. Hence, the reduction of its emissions is an important stake for the improvement of air quality. In recent years, control of ammonia emissions has become a major concern at regional, national, and international levels and, since the end of the 1990s, a set of regulations has been put in place. To further reduce ammonia emissions, improve air quality, and optimize costs and benefits requires a better knowledge and quantification of ammonia sources and also an analysis of long-term strategies. France regularly undergoes peaks of aerosol pollution $\left(\mathrm{PM}_{10}-\mathrm{PM}_{2.5}\right)$, especially at the end of winter-early spring, when favourable weather conditions coincide with the beginning of fertilizer spreading. In March 2014, high PM2.5 concentrations were observed in the Paris region, leading to the introduction of alternating traffic, and therefore made citizens particularly aware of the issues of air quality. Predicting air quality at the regional level is crucial to understand these episodes and to recommend appropriate levers of action in the short term to limit the magnitude of these episodes. Air pollution affects not only human health, but also the overall productivity of ecosystems and crop yields, through increased dry deposition of $\mathrm{N}$ compounds and $\mathrm{O}_{3}$, which in turn could affect BVOC emissions. In addition, by modifying plant functioning in terms of evapotranspiration and soil moisture status, ozone deposition may affect the hydrological cycle, which in turn will affect surface but also wet deposition of pollutants and nutrients.

We have here a typical example where scientists involved in agronomy, physics, biology, and chemistry should interact to improve predictions of ammonia emissions, transport and reactions related to weather conditions, soil biological processes, and plant phenology, to estimate feedbacks of air pollution on the functioning of involved ecosystems. However, to solve the problem, cooperation between farmers, urban planners, and decision makers is required to define optimal fertilization dates and a territorial planning of urban and peri-urban areas that accounts for the distribution of agricultural activities around the city.

\subsubsection{Urban greening - UHI - and impact on VOC- $-\mathrm{NO}_{x}-\mathrm{O}_{3}$ loop}

Many studies have explored techniques to counterbalance the deleterious effects of urbanization on the local environment. Among the numerous solutions already proposed, urban greening is one of the most interesting since it could allow (i) an attenuation of the UHI (e.g. Shashua-Bar and Hoffman, 2000; Alexandri and Jones, 2008; Feyisa et al., 2014), (ii) a direct mitigation of air pollution via the absorption of pollutants by plants (Hill, 1971), and (iii) an indirect improvement of air quality through UHI mitigation since tem- 
perature partly drives and controls pollutant emission, dispersion, and formation (Sini et al., 1996; Kim and Baik, 1999; Stathopoulou et al., 2008).

On the one hand, green surfaces such as parks, gardens, or green roofs and walls contribute to mitigating the UHI and currently receive strong attention from both scientists and urban planners (e.g. Shashua-Bar and Hoffman, 2000; Akbari et al., 2001; Kumar and Kaushik, 2005; Alexandri and Jones, 2008; Feyisa et al., 2014) with some interdisciplinary and inter-community experiences already established (e.g. the Urban Climate Change Research Network, http://uccrn.org/, last access date: 22 May 2019; the MAPUCE project in Toulouse, https://anr.fr/Project-ANR-13-VBDU-0004, last access date: 7 June 2019, local projects in Stuttgart, New York). On the other hand, a growing number of studies focus on urban air quality assessment to quantify impacts of urban vegetation (e.g. Yang et al., 2005; Novak et al., 2006; Escobedo et al., 2011; Selmi et al., 2016). Changes in planted species and their surfaces can indeed significantly impact the amount and fate of reactive compounds emitted, such as biogenic VOCs or nitrogen compounds, and therefore affect the air chemical composition in terms of gases and aerosols (Ghirardo et al., 2016; Janhäll, 2015; Taha et al., 2016). Nevertheless, feedbacks on air quality by UHI mitigation are not accounted for but could lead to air quality degradation, by affecting pollutant and especially ozone precursor dispersion (Lai and Cheng, 2009). To quantify to which extent urban greening can help to mitigate urban local climate and atmospheric pollution, and its subsequent effects at the regional scale, it is therefore necessary to adopt interdisciplinary approaches (Baró et al., 2014), involving atmospheric physics and chemistry, but also urban planners. Indeed, although the role of urban form, urban fabric, and building arrangement and orientation in UHI mitigation was explored in previous studies (Stone and Norman, 2006; Emmanuel and Fernando, 2007; Shahmohamadi et al., 2010; Middel et al., 2014), this was not the case for atmospheric composition.

\subsection{Bridge the gap between communities: the need for developments in the interplay between climate scientists and spatial planners}

The knowledge, the instrumentation, and the expertise developed over the last decades regarding land surfaceatmosphere interactions and their impacts on local-toregional climate and air quality could deliver operational and useful outcomes for policymakers and land planners, and thus benefits for populations, activities, and ecosystems. One action that can help bridge this gap is to introduce (or reintroduce) climate expertise into the spatial planning process. The climate issue has clearly become one of the main priorities of planning authorities throughout the world (e.g. Bulkeley, 2006; Wilson and Piper, 2010; Davoudi et al., 2009) in response to the widespread call for fighting global change in many fields and scales of policy. However, relatively few planning authorities directly call upon climate experts. This absence of climate expertise leads planners to ignore many levers of action at local and/or regional scales, some of them being described throughout this article.

Today, more and more urban planning authorities develop in-house climate expertise, with sometimes interesting results. For example, efforts are being made in an increasing number of cities in reduce the urban heat island effect (Ren et al., 2011; Cordeau, 2014). These additional climate skills are nevertheless largely dedicated to urban areas and consequently face difficulties in considering the influence of surface-atmosphere interactions at broader spatial scales. They generally also hardly consider the interplay between climate and air quality issues. There are, however, a few cases that can be sources of inspiration. For instance, for the Stuttgart metropolitan area, which is $3654 \mathrm{~km}^{2}$, the city of Stuttgart's Department of Urban Climatology produced a climatic atlas, based on a climatope approach to assess the influence of spatial units with similar microclimatic characteristics on atmospheric conditions (Baumüller, 2008). This initiative resulted in urban and spatial planning guidance, with the objective to improve the flow of fresh air from the agricultural and natural areas and thus to refresh, clean up, and prevent temperature inversion above built surfaces. The development of local-to-regional actions taking advantage of multiple surface-to-atmosphere interactions can hardly be conceived without using regional meteorological or climate models, since the same land use or land management direction can have very different and even inverse consequences, depending on the context (Marshall et al., 2004a; Schneider and Eugster, 2007; Lobell et al., 2007; DeAngelis et al., 2010). An example of successful collaborations between communities is the digital modelling platform built within the framework of the ACCLIMAT project (https:// www.umr-cnrm.fr/ville.climat/spip.php?rubrique47, last access: 22 May 2019). This platform allows the numerical modelling of different processes of the city system and their interactions. The developed physical- and urban-based models are forced by socio-economic scenarios of urban development and local climatic scenarios. It is then possible to produce different city projections, from the present day to the end of the century, under different future climate conditions, and to estimate the impacts of these cities on urban climate or on building energy consumption.

Another difficulty to develop a collaborative action lies, among others, in the spatial gap between the respective scales of reference of climate scientists and spatial planners. Climate models have not yet sufficiently been tested at the intermediate spatial scales that are generally considered by planners in their practice. Regional climate models often work at resolutions lower than $15 \mathrm{~km} \times 15 \mathrm{~km}$, while urban climate models work on meshes of about $1 \mathrm{~km} \times 1 \mathrm{~km}$. There is therefore a need to develop models functioning at intermediate scales and integrating a description of land surfaces 
closer to the definitions and representations used by spatial and urban planners.

Lastly, we need to give more attention today to the modifications created by land use management (e.g. agricultural and forestry practices) on top of land use at a regional and global scale. For climate scientists, this means identifying levers of action, among those proposed by practitioners, in terms of land use management, that can influence climate and air quality. For planners, this is another challenge emerging, questioning the contours of their field of activity, the discipline focusing historically on land use and surface occupancy.

\section{Conclusion}

Land-atmosphere interactions involve many physical, biological, and chemical processes that can all influence each other, and that are driven by the characteristics of the environment in which they take place (meteorological conditions, surface properties, etc.). To properly investigate the role and impact of land-atmosphere interactions, especially in the context of LULCCs, on local to regional climate and air quality, the most appropriate and comprehensive tools are required. It is difficult today to design experimental protocols at the regional scale that allow us to identify interactions and impacts of specific processes. When modelling such interactions, one has to recognize that the description of land use and land management (areas concerned, type of crops, quantity of fertilizers used and actual seasonality of application, etc.), including surface properties and emission sources, are overly simplified in today's models. Not taking into account the land surface characteristics certainly biases our projections. Moreover, land-atmosphere interactions are often specific to the target landscape, especially at a local/regional scale; therefore, in this perspective, one can hardly propose general solutions or recommendations. Hence, there is a crucial need for a consistent description of surface characteristics in numerical tools, to both improve our knowledge and provide more appropriate information to urban and land planners and stakeholders at the territory and local scale. Urban and peri-urban areas are of particular attention in this context since land transformation can have big environmental impacts and affect the health and life of millions of people, given the human density in these areas. For example, there is space for considering the links between atmospheric chemistry and land-atmosphere interactions, as a decision parameter for land management, helping to maintain air quality and supporting ecosystem functioning. This leads us to touch on the notion of ecosystem services, which is an integrated approach that allows us to effectively analyse and examine the ecosystem conditions in terms of whether or not the desired services are being delivered. Ecosystem services are highly interlinked, and any kind of human influence on the functioning of one service will likely have a large number of knock- down effects on other services. The types of ecosystem services dealing with the climate and the atmosphere come under the category of regulating services, which were identified and categorized in several studies (Cooter et al., 2013; Thornes et al., 2010). Nevertheless, the feedbacks of the atmosphere to the ecosystem functioning potentially affect the ability of those ecosystems to provide services to the human population.

Data availability. No data sets were used in this article.

Supplement. The supplement related to this article is available online at: https://doi.org/10.5194/bg-16-2369-2019-supplement.

Author contributions. RSM and JL equally contributed in the conception, outline design, writing, and reviewing of the paper. SuS contributed to writing parts of the paper relative to physical and chemical processes and to reviewing the paper. NdND has solicited this review in the context of the LabEx BASC, and participated in the conception of the paper and contributed to writing the discussion. MS and PS contributed to writing parts of the paper relative to physical processes. SoS contributed to writing parts of the paper relative to chemical processes. EP contributed to writing parts of the paper relative to biological processes. MP contributed to writing parts of the paper relative to urban planning, and LULCC. All authors participated in the outline design and reviewed the paper.

Competing interests. The authors declare that they have no conflict of interest.

Acknowledgements. This work was supported by a grant overseen by the French National Research Agency (ANR) as part of the "Investments d'Avenir" programme (LabEx BASC; ANR-11-LABX0034). The work of Marc Stéfanon was supported by the French National Research Agency (ANR) as part of the project Forewer (ANR-14-CE05-0028).

Review statement. This paper was edited by Akihiko Ito and reviewed by two anonymous referees.

\section{References}

Abhijith, K. V., Kumar, P., Gallagher, J., McNabola, A., Baldauf, R., Pilla, F., Broderick, B., Di Sabatino, S., and Pulvirenti, B.: Air pollution abatement performances of green infrastructure in open road and built-up street canyon environments - A review, Atmos. Environ., 162, 71-86, https://doi.org/10.1016/j.atmosenv.2017.05.014, 2017.

Adegoke, J. O., Pielke, R. A., Eastman, J., Mahmood, R., and Hubbard, K. G.: Impact of irrigation on midsummer sur- 
face fluxes and temperature under dry synoptic conditions: A regional atmospheric model study of the U.S. high plains, Mon. Weather Rev., 131, 556-564, https://doi.org/10.1175/15200493(2003)131<0556:IOIOMS>2.0.CO;2, 2003.

Adji, F. F., Hamada, Y., Darang, U., Limin, S. H., and Hatano, R.: Effect of plant-mediated oxygen supply and drainage on greenhouse gas emission from a tropical peatland in Central Kalimantan, Indonesia, Soil Sci. Plant Nutr., 60, 216-230, https://doi.org/10.1080/00380768.2013.872019, 2014.

Ainsworth, E. A., Yendrek, C. R., Sitch, S., Collins, W. J., and Emberson, L. D.: The Effects of Tropospheric Ozone on Net Primary Productivity and Implications for Climate Change, Annu. Rev. Plant Biol., 63, 637-661, https://doi.org/10.1146/annurevarplant-042110-103829, 2012.

Akbari, H., Pomerantz, M., and Taha, H.: Cool surfaces and shade trees to reduce energy use and improve air quality in urban areas, Sol. Energy, 70, 295-310, 2001.

Alchapar, N. L., Correa, E. N., and Cantón, M. A.: Classification of building materials used in the urban envelopes according to their capacity for mitigation of the urban heat island in semiarid zones, Energ. Buildings, 69, 22-32, 2014.

Alexandri, E. and Jones, P.: Temperature decreases in an urban canyon due to green walls and green roofs in diverse climates, Build. Environ., 43, 480-493, 2008.

Allen, A.: Environmental planning and management of the peri-urban interface: perspectives on an emerging field, Environ. Planning and Management, 15, 135-148, https://doi.org/10.1177/095624780301500103, 2003.

Alletto, L., Coquet, Y., Benoit, P., Heddadj, D., and Barriuso, E.: Tillage management effects on pesticide fate in soils. A review, Agron. Sustain. Dev., 30, 367-400, https://doi.org/10.1051/agro/2009018, 2010.

Alpert, P. and Kishcha, P.: Quantification of the effect of urbanization on solar dimming, Geophys. Res. Lett., 35, L08801, https://doi.org/10.1029/2007GL033012, 2008.

Alpert, P., Kishcha, P., Kaufman, Y., and Schwarzbard, R.: Global dimming or local dimming?: Effect of urbanizationon sunlight availability, Geophys. Res. Lett., 32, L17802, https://doi.org/10.1029/2005GL023320, 2005.

Anav, A., Ruti, P. M., Artale, V., and Valentini, R.: Modelling the effects of land-cover changes on surface climate in the Mediterranean region, Clim. Res., 41, 91-104, https://doi.org/10.3354/cr00841, 2010.

André, J. C., Bougeault, P., and Goutorbe, J. P.: Regional estimates of heat and evaporation fluxes over non-homogeneous terrain. Examples from the HAPEX-MOBILHY programme, Bound.Lay. Meteorol., 50, 77-108, 1990.

Anthes, R. A.: Enhancement of convective precipitation by mesoscale variations in vegetative covering in semiarid regions, J. Clim. Appl. Meteorol., 23, 541-554, 1984.

Arneth, A., Monson, R. K., Schurgers, G., Niinemets, Ü., and Palmer, P. I.: Why are estimates of global terrestrial isoprene emissions so similar (and why is this not so for monoterpenes)?, Atmos. Chem. Phys., 8, 4605-4620, https://doi.org/10.5194/acp8-4605-2008, 2008.

Arneth, A., Harrison, S. P., Zaehle, S., Tsigaridis, K., Menon, S., Bartlein, P. J., Feichter, J., Korhola, A., Kulmala, M., O’Donnell, D., Schurgers, G., Sorvari, S., and Vesala, T.: Terrestrial biogeo- chemical feedbacks in the climate system, Nat. Geosci., 3, 525532, 2010.

Arneth, A., Mercado, L., Kattge, J., and Booth, B. B. B.: Future challenges of representing land-processes in studies on land-atmosphere interactions, Biogeosciences, 9, 3587-3599, https://doi.org/10.5194/bg-9-3587-2012, 2012.

Arnfield, A. J.: Two decades of urban climate research: a review of turbulence, exchanges of energy and water, and the urban heat island, Int. J. Climatol., 23, 1-26, 2003.

Ashworth, K., Folberth, G., Hewitt, C. N., and Wild, O.: Impacts of near-future cultivation of biofuel feedstocks on atmospheric composition and local air quality, Atmos. Chem. Phys., 12, 919939, https://doi.org/10.5194/acp-12-919-2012, 2012.

Ashworth, K., Wild, O., and Hewitt, C. N.: Impacts of biofuel cultivation on mortality and crop yields, Nat. Clim. Change, 3, 492496, https://doi.org/10.1038/nclimate1788, 2013.

Avissar, R. and Liu, Y.: Three-dimensional numerical study of shallow convective clouds and precipitation induced by land surface forcing, J. Geophys. Res.-Atmos., 101, 7499-7518, 1996.

Avissar, R. and Pielke, A. R.: A parameterization of heterogeneous land surfaces for atmospheric numerical models and its impact on regional meteorology, Mon. Weather Rev., 117, 2113-2136, 1989.

Avissar, R. and Schmidt, T.: An evaluation of the scale at which ground-surface heat flux patchiness affects the convective boundary layer using large-eddy simulations, J. Atmos. Sci., 55, 2666 2689, 1998.

Bakker, M. M., Govers, G., Kosmas, C., Vanacker, V., van Oost, K., and Rounsevell, M.: Soil erosion as a driver of land-use change, Agr. Ecosys. Environ., 105, 467-481, https://doi.org/10.1016/j.agee.2004.07.009, 2005.

Baklanov, A., Beekmann, M., Jaffrezo, J.-L., Jimenez, J.-L., Reeves, C., and Vautard, R. (Eds.): Megapoli-Paris 2009/2010 campaign, available at: https://www.atmos-chem-phys.net/ special_issue248.html, 2011.

Baklanov, A., Schlünzen, K., Suppan, P., Baldasano, J., Brunner, D., Aksoyoglu, S., Carmichael, G., Douros, J., Flemming, J., Forkel, R., Galmarini, S., Gauss, M., Grell, G., Hirtl, M., Joffre, S., Jorba, O., Kaas, E., Kaasik, M., Kallos, G., Kong, X., Korsholm, U., Kurganskiy, A., Kushta, J., Lohmann, U., Mahura, A., Manders-Groot, A., Maurizi, A., Moussiopoulos, N., Rao, S. T., Savage, N., Seigneur, C., Sokhi, R. S., Solazzo, E., Solomos, S., Sørensen, B., Tsegas, G., Vignati, E., Vogel, B., and Zhang, Y.: Online coupled regional meteorology chemistry models in Europe: current status and prospects, Atmos. Chem. Phys., 14, 317-398, https://doi.org/10.5194/acp-14-317-2014, 2014.

Baklanov, A., Grimmond, C. S. B., Carlson, D., Terblanche, D., Tang, X., Bouchet, V., Lee, B., Langendijk, G., Kolli, R. K., and Hovsepyan, A.: From urban meteorology, climate and environment research to integrated city services, Urban Climate, 23, 330-341, https://doi.org/10.1016/j.uclim.2017.05.004, 2018.

Bala, G., Caldeira, K., Wickett, M., Phillips, T. J., Lobell, D. B., Delire, C., and Mirin, A.: Combined climate and carbon-cycle effects of large-scale deforestation, P. Natl. Acad. Sci. USA, 114, 6550-6555, 2007.

Baró, F., Chaparro, L., Gómez-Baggethun, E., Langemeyer, J., Nowak, D. J., and Terradas, J.: Contribution of Ecosystem Services to Air Quality and Climate Change Mitigation Policies: The 
Case of Urban Forests in Barcelona, Spain, AMBIO, 43, 466479, https://doi.org/10.1007/s13280-014-0507-x, 2014.

Bash, J. O., Cooter, E. J., Dennis, R. L., Walker, J. T., and Pleim, J. E.: Evaluation of a regional air-quality model with bidirectional $\mathrm{NH}_{3}$ exchange coupled to an agroecosystem model, Biogeosciences, 10, 1635-1645, https://doi.org/10.5194/bg-101635-2013, 2013.

Baumgardner, D., Varela, S., Escobedo, F. J., Chacalo, A., and Ochoa, C.: The role of a peri-urban forest on air quality improvement in the Mexico City megalopolis, Environ. Pollut., 163, 174183, https://doi.org/10.1016/j.envpol.2011.12.016, 2012.

Baumüller, J.: Klimaatlas Region Stuttgart, Verband Region Stuttgart, Stuttgart, 2008.

Bellassen, V. and Luyssaert, S.: Carbon sequestration: Managing forests in uncertain times, Nature, 506, 153-155, 2014

Beltman, J. B., Hendriks, C., Tum, M., and Schaap, M.: The impact of large scale biomass production on ozone air pollution in Europe, Atmos. Environ., 71, 352-363, 2013.

Beltran-Przekurat, A., Pielke Sr., R. A., Eastman, J. L., and Coughenour, M. B.: Modelling the effects of landuse/land-cover changes on the near-surface atmosphere in southern South America, Int. J. Climatol., 32, 1206-1225, https://doi.org/10.1002/joc.2346, 2012.

Benjamin, M. and Winer, A. M.: Estimating the ozone-forming potential of urban trees and shrubs, Atmos. Environ., 32, 53-56, 1998.

Benjamin, M. T., Sudol, M., Bloch, L., and Winer, A. M.: Low emitting urban forests: a taxonomic methodology for assigning isoprene and monoterpenes emission rates, J. Atmos. Environ., 30, 1437-1452, 1996.

Benton, T. G., Vickery, J. A., and Wilson, J. D.: Farmland biodiversity: is habitat heterogeneity the key?, Trends Ecol. Evol., 18, 182-188, https://doi.org/10.1016/S0169-5347(03)00011-9, 2003.

Berenguer, E., Ferreira, J., Gardner, T. A., Aragão, L. E. O. C., De Camargo, P. B., Cerri, C. E., Durigan, M., Oliveira, R. C. D., Vieira, I. C. G., and Barlow, J.: A large-scale field assessment of carbon stocks in human-modified tropical forests, Glob. Change Biol., 20, 3713-3726, https://doi.org/10.1111/gcb.12627, 2014.

Bergkamp, G. and Orlando, B.: Wetlands and climate change: exploring collaboration between the Convention on wetlands [Ramsar, Iran 1971] and the UN Framework Convention on Climate Change, IUCN, available at: https://portals.iucn.org/library/ node/12367 (last access: 22 May 2019), 1999.

Beringer, T. I. M., Lucht, W., and Schaphoff, S.: Bioenergy production potential of global biomass plantations under environmental and agricultural constraints, GCB Bioenergy, 3, 299-312, 2011.

Bertram, T. H., Heckel, A., Richter, A., Burrows, J. P., and Cohen, R. C.: Satellite measurements of daily variations in soil $\mathrm{NO}_{x}$ emissions, Geophys. Res. Lett., 32, L24812, https://doi.org/10.1029/2005GL024640, 2005.

Betts, R. A.: Biogeophysical impacts of land use on present-day climate: Near-surface temperature change and radiative forcing, Atmos. Sci. Lett., 2, 39-51, 2001.

Betts, R. A., Falloon, P. D., Klein Goldewijk, K., and Ramankutty, N.: Biogeophysical effects of land use on climate: Model simulations of radiative forcing and large-scale temperature change, Agr. Forest Meteorol., 142, 216-233, 2007.
Boerner, R.: Fire and Nutrient Cycling in Temperate Ecosystems, BioScience, 32, 187-192, https://doi.org/10.2307/1308941, 1982.

Bohnenstengel, S. I., Evans, S., Clark, P. A., and Belcher, S. E.: Simulations of the London urban heat island, Q, J. Roy. Meteor. Soc., 137, 1625-1640, 2011.

Boisier, J. P., de Noblet-Ducoudré, N., Pitman, A. J., Cruz, F. T., Delire, C., van den Hurk, B. J. J. M., van der Molen, M. K., Müller, C., and Voldoire, A.: Attributing the impacts of land-cover changes in temperate regions on surface temperature and heat fluxes to specific causes: Results from the first LUCID set of simulations, J. Geophys. Res.-Atmos., 117, D12116, https://doi.org/10.1029/2011jd017106, 2012.

Bonan, G. B.: Effects of land use on the climate of the United States, Climatic Change, 37, 449-486, 1997.

Bonan, G. B.: Forests and Climate Change: Forcings, Feedbacks, and the Climate Benefits of Forests, Science, 320, 1444-1449, https://doi.org/10.1126/science.1155121, 2008.

Bonfils, C. and Lobell, D.: Empirical evidence for a recent slowdown in irrigation-induced cooling, P. Natl. Acad. Sci. USA, 104, 13582-13587, 2007.

Bonn, B., von Schneidemesser, E., Butler, T., Churkina, G., Ehlers, C., Grote, R., Klemp, D., Nothard, R., Schäfer, K., von Stülpnagel, A., Kerschbaumer, A., Yousefpour, R., Fountoukis, C., and Lawrence, M. G.: Impact of vegetative emissions on urban ozone and biogenic secondary organic aerosol: Box model study for Berlin, Germany, J. Clean. Prod., 176, 827-841, https://doi.org/10.1016/j.jclepro.2017.12.164, 2018.

Bormann, F. H. and Likens, G. E.: Pattern and Process of a Forested System, Springer-Verlag, New York, 1979.

Boucher, O., Myhre, G., and Myhre, A.: Direct human influence of irrigation on atmospheric water vapour and climate, Clim. Dynam., 22, 597-603, 2004.

Bounoua, L., DeFries, R., Collatz, G. J., Sellers, P., and Khan, H.: Effects of land cover conversion on surface climate, Climatic Change, 52, 29-64, 2002.

Bouwman, A. F.: Exchange of greenhouse gases between terrestrial ecosystems and the atmosphere, edited by: Bouwman, A. F., 61127, Wiley, Chichester, 1990.

Bozzi, E., Genesio, L., Toscano, P., Pieri, M., and Miglietta, F.: Mimicking biochar-albedo feedback in complex Mediterranean agricultural landscapes, Environ. Res. Lett., 10, 84014, https://doi.org/10.1088/1748-9326/10/8/084014, 2015.

Brandsma, T., Können, G. P., and Wessels, H. R. A.: Empirical estimation of the effect of urban heat advection on the temperature series of de Bilt (The Netherlands), Int. J. Climatol., 23, 829845, 2003.

Brazel, A., Selover, N., Vose, R., and Heisler, G.: The tale of two climates - Baltimore and Phoenix urban LTER sites, Clim. Res., 15, 123-135, https://doi.org/10.3354/Cr015123, 2000.

Bremner, J. M. and Blackmer, A. M.: Nitrous Oxide: Emission from Soils During Nitrification of Fertilizer Nitrogen, Science, 199 295-296, https://doi.org/10.1126/science.199.4326.295, 1978.

Briggs, G. A.: Surface inhomogeneity effects on convective diffusion, Bound.-Lay. Meteorol., 45, 117-135, 1988.

Brovkin, V., Ganopolski, A., Claussen, M., Kubatzki, C., and Petoukhov, V.: Modelling climate response to historical land cover change, Global Ecol. Biogeogr., 8, 509-517, 1999. 
Brovkin, V., Claussen, M., Driesschaert, E., Fichefet, T., Kicklighter, D., Loutre, M. F., Matthews, H. D., Ramankutty, N., Schaeffer, M., and Sokolov, A.: Biogeophysical effects of historical land cover changes simulated by six Earth system models of intermediate complexity, Clim. Dynam., 26, 587-600, 2006.

Bulkeley, H.: A changing climate for spatial planning?, Planning Theory and Practice, 7, 203-214, 2006.

Bytnerowicz, A., Cayan, D., Riggan, P., Schilling, S., Dawson, P., Tyree, M., Wolden, L., Tissell, R., and Preisler, H.: Analysis of the effects of combustion emissions and Santa Ana winds on ambient ozone during the October 2007 southern California wildfires, Atmos. Environ., 44, 678-687, 2010.

Caballero-López, B., Bommarco, R., Blanco-Moreno, J. M., Sans, F. X., Pujade-Villar, J., Rundlöf, M., and Smith, H. G.: Aphids and their natural enemies are differently affected by habitat features at local and landscape scales, Biol. Control, 63, 222-229, https://doi.org/10.1016/j.biocontrol.2012.03.012, 2012.

Calfapietra, C., Ainsworth, E. A., Beier, C., De Angelis, P., Ellsworth, D. S., Godbold, D. L., Hendrey, G. R., Hickler, T., Hoosbeek, M. R., and Karnosky, D. F.: Challenges in elevated $\mathrm{CO}_{2}$ experiments on forests, Trends Plant Sci., 15, 5-10, https://doi.org/10.1016/j.tplants.2009.11.001, 2010.

Calfapietra, C., Fares, S., Manes, F., Morani, A., Sgrigna, G., and Loreto, F.: Role of Biogenic Volatile Organic Compounds (BVOC) emitted by urban trees on ozone concentration in cities: A review, Environ. Pollut., 183, 71-80, https://doi.org/10.1016/j.envpol.2013.03.012, 2013.

Calfapietra, C., Peñuelas, J., and Niinemets, Ü.: Urban plant physiology: adaptation-mitigation strategies under permanent stress, Trends Plant Sci., 20, 72-75, https://doi.org/10.1016/j.tplants.2014.11.001, 2015.

Cardelino, C. A. and Chameides, W. L.: Natural hydrocarbons, urbanization, and urban ozone, J. Geophys. Res., 95, 13971-13979, 1990.

Casella, E.: Long-term effects of $\mathrm{CO}_{2}$ enrichment and temperature increase on the carbon balance of a temperate grass sward, J. Exp. Bot., 48, 1309-1321, 1997.

Chabbi, A., Senapati, N., Giostri, A., Vertes, F., Carrozi, M., Lemaire, G., Gastal, F., Recous, S., Klumpp, K., Massad, R. S., and Rumpel, C.: Use of ley-arable rotations improves greenhouse gas (GHG) emissions and carbon balance, Fourrages, 223, 241248, 2015

Chagnon, F. J. F., Bras, R. L., and Wang, J.: Climatic shift in patterns of shallow clouds over the Amazon, Geophys. Res. Lett., 31, 24212, https://doi.org/10.1029/2004GL021188, 2004.

Chalita, S. and Le Treut, H.: The albedo of temperate and boreal forest and the Northern Hemisphere climate: a sensitivity experiment using the LMD GCM, Clim. Dynam., 10, 231-240, 1994.

Chameides, W. L., Lindsay, R. W., Richardsen, J., and Kiang, C. S.: The role of biogenic hydrocarbons in urban photochemical smog: Atlanta as a case study, Science, 241, 1473-1475, 1988.

Chaplot, V., Bouahom, B., and Valentin, C.: Soil organic carbon stocks in Laos: spatial variations and controlling factors, Glob. Change Biol., 16, 1380-1393, https://doi.org/10.1111/j.13652486.2009.02013.x, 2010.

Charney, J. G., Stone, P. H., and Quirk, W. J.: Drought in the Sahara: A biogeophysical mechanism, Science, 187, 434-435, 1975.
Charney, J. G., Quirk, W. J., Chow, S., and Kornfield, J.: A Comparative Study of the Effects of Albedo Change on Drought in Semi-Arid Regions, J. Atmos. Sci., 34, 1366-1385, 1977.

Chen, J., Avise, J., Guenther, A., Wiedinmyer, C., Salathe, E., Jackson, R. B., and Lamb, B.: Future land use and land cover influences on regional biogenic emissions and air quality in the United States, Atmos. Environ., 43, 5771-5780, https://doi.org/10.1016/j.atmosenv.2009.08.015, 2009.

Chen, S., Zhao, C., Qian, Y., Leung, L. R., Huang, J., Huang, Z., Bi, J., Zhang, W., Shi, J., Yang, L., Li, D., and Li, J.: Regional modeling of dust mass balance and radiative forcing over East Asia using WRF-Chem, Aeolian Res., 15, 15-30, https://doi.org/10.1016/j.aeolia.2014.02.001, 2014.

Chen, X.-L., Li, P.-X., and Yin, Z.-Y.: Remote sensing imagebased analysis of the relationship between urban heat island and land use/cover changes, Remote Sens. Environ., 104, 133-146, https://doi.org/10.1016/j.rse.2005.11.016, 2006.

Christen, A. and Vogt, R.: Energy and radiation balance of a central European city, Int. J. Climatol., 43, 1395-1421, 2004.

Christensen, N. L.: Fire and soil-plant nutrient relations in a pinewiregrass savanna on the coastal plain of North Carolina, Oecologia, 31, 27-44, https://doi.org/10.1007/BF00348706, 1977.

Christensen, N. L. and Muller, C. H.: Effects of Fire on Factors Controlling Plant Growth in Adenostoma Chaparral, Ecol. Monogr., 45, 29-55, https://doi.org/10.2307/1942330, 1975.

Christy, J. R., Norris, W. B., Redmond, K., and Gallo, K. P.: Methodology and results of calculating central California surface temperature trends: evidence of human-induced climate change?, J. Climate, 19, 548-563, 2006.

Churkina, G., Trusilova, K., Vetter, M., and Dentener, F.: Contributions of nitrogen deposition and forest regrowth to terrestrial carbon uptake, Carbon Balance and Management, 2, 5, https://doi.org/10.1186/1750-0680-2-5, 2007.

Churkina, G., Grote, R., Butler, T. M., and Lawrence, M.: Natural selection? Picking the right trees for urban greening, Environ. Sci. Policy, 47, 12-17, https://doi.org/10.1016/j.envsci.2014.10.014, 2015.

Churkina, G., Kuik, F., Bonn, B., Lauer, A., Grote, R., Tomiak, K., and Butler, T. M.: Effect of VOC Emissions from Vegetation on Air Quality in Berlin during a Heatwave, Environ. Sci. Technol., 51, 6120-6130, https://doi.org/10.1021/acs.est.6b06514, 2017.

Cinnadurai, C., Gopalaswamy, G., and Balachandar, D.: Diversity of cultivable Azotobacter in the semi-arid alfisol receiving longterm organic and inorganic nutrient amendments, Ann. Microbiol., 63, 1397-1404, https://doi.org/10.1007/s13213-013-06006, 2013.

Civerolo, K., Hogrefe, C., Lynn, B., Rosenthal, J., Ku, J. Y., and Solecki, W., Cox, J., Small, C., Rosenzweig, C., Goldberg, R., Knowlton, K., and Kinney, P.: Estimating the effects of increased urbanization on surface meteorology and ozone concentrations in the New York City metropolitan region, Atmos. Environ., 41, 1803-1818, 2007.

Civerolo, K., Sistla, G., Rao, S., and Nowak, D.: The effects of land use in meteorological modeling: implications for assessment of future air quality scenarios, Atmos. Environ., 34, 1615-1621, https://doi.org/10.1016/S1352-2310(99)00393-3, 2000.

Classen, A. T., Sundqvist, M. K., Henning, J. A., Newman, G. S., Moore, J. A. M., Cregger, M. A., Moorhead, L. C., and Patterson, C. M.: Direct and indirect effects of climate change on soil mi- 
crobial and soil microbial-plant interactions: What lies ahead?, Ecosphere, 6, 130, https://doi.org/10.1890/ES15-00217.1, 2015.

Claussen, M., Brovkin, V., and Ganopolski, A.: Biogeophysical versus biogeochemical feedbacks of large-scale land cover change, Geophys. Res. Lett., 28, 1011-1014, 2001.

Cook, B. I., Puma, M. J., and Krakauer, N. Y.: Irrigation induced surface cooling in the context of modern and increased greenhouse gas forcing, Clim. Dynam., 37, 1587-1600, 2011.

Cook, B. I., Shukla, S. P., Puma, M. J., and Nazarenko, L. S.: Irrigation as an historical climate forcing, Clim. Dynam., 44, 17151730, 2015.

Cooter, E. J., Rea, A., Bruins, R., Schwede, D., and Dennis, R.: The role of the atmosphere in the provision of ecosystem services, Sci. Total Environ., 448, 197-208, https://doi.org/10.1016/j.scitotenv.2012.07.077, 2013.

Corchnoy, S. B., Arey, J., and Atkinson, R.: Hydrocarbon emissions from twelve urban shade trees of the Los Angeles, California, air basin, Atmos. Environ. B-Urb., 26, 339-348, 1992.

Cordeau, E.: La vulnérabilité de la ville à la chaleur par l'approche zones climatiques locales, Note Rapide Environnement, Vol. 661, available at: https://www.iau-idf.fr/ fileadmin/NewEtudes/Etude_1103/NR_661_web.pdf (last access: 22 May 2019), 2014.

Costamagna, A. C., Menalled, F. D., and Landis, D. A.: Host density influences parasitism of the armyworm Pseudaletia unipuncta in agricultural landscapes, Basic Appl. Ecol., 5, 347355, https://doi.org/10.1016/j.baae.2004.04.009, 2004.

Covington, W. W.: Secondary succession in northern hardwoods: Forest floor organic matter and nutrients and leaf fall, Yale University, New Haven, Conneticut, 1976.

Crutzen, P. J. and Andreae, M. O.: Biomass burning in the Tropics - impact on atmospheric chemistry and biogeochemical cycles, Science, 250, 1669-1678, 1990.

Dale, A. G. and Frank, S. D.: The Effects of Urban Warming on Herbivore Abundance and Street Tree Condition, Plos One, 9, e102996, https://doi.org/10.1371/journal.pone.0102996, 2014.

Davidson, N. C.: How much wetland has the world lost? Long-term and recent trends in global wetland area, Mar. Freshwater Res., 65, 934-941, 2014.

Davin, E. L. and de Noblet-Ducoudré, N.: Climatic impact of global-scale deforestation: Radiative versus nonradiative processes, J. Climate, 23, 97-112, 2010.

Davin, E. L., Seneviratne, S. I., Ciais, P., Olioso, A., and Wang, T.: Preferential cooling of hot extremes from cropland albedo management, P. Natl. Acad. Sci. USA, 111, 9757-9761, 2014.

Davoudi, S., Crawford, J., and Mehmood, A. (Eds.): Planning for climate change: strategies for mitigation and adaptation for spatial planners, Earthscan, London, Sterling, VA, 2009.

DeAngelis, A., Dominguez, F., Fan, Y., Robock, A., Kustu, M. D., and Robinson, D.: Evidence of enhanced precipitation due to irrigation over the Great Plains of the United States, J. Geophys. Res.-Atmos., 115, 15115, https://doi.org/10.1029/2010JD013892, 2010.

Debano, L. F. and Conrad, C. E.: The Effect of Fire on Nutrients in a Chaparral Ecosystem, Ecology, 59, 489-497, https://doi.org/10.2307/1936579, 1978.

de Blécourt, M., Brumme, R., Xu, J., Corre, M. D., and Veldkamp, E.: Soil Carbon Stocks Decrease following Conversion of Secondary Forests to Rubber (Hevea brasiliensis) Plantations, PLoS
ONE, 8, e69357, https://doi.org/10.1371/journal.pone.0069357, 2013.

de Noblet-Ducoudré, N., Boisier, J. P., Pitman, A., Bonan, G. B., Brovkin, V., Cruz, F., Delire, C., Gayler, V., Van den Hurk, B. J. J. M., and Lawrence, P. J.: Determining robust impacts of landuse-induced land cover changes on surface climate over North America and Eurasia: results from the first set of LUCID experiments, J. Climate, 25, 3261-3281, 2012.

de Ruijter, F. J., Huijsmans, J. F. M., and Rutgers, B.: Ammonia volatilization from crop residues and frozen green manure crops, Atmos. Environ., 44, 3362-3368, https://doi.org/10.1016/j.atmosenv.2010.06.019, 2010.

Dickinson, R. E. and Kennedy, P.: Impacts on regional climate of Amazon deforestation, Geophys. Res. Lett., 19, 1947-1950, 1992.

Dominski, A. S.: Accelerated nitrate production and loss in the northern hardwood forest ecosystem underlain by podsol soils following clearcutting and addition of herbicides, $\mathrm{PhD}$ thesis, Yale University, 1971.

Dooley, S. R. and Treseder, K. K.: The effect of fire on microbial biomass: a meta-analysis of field studies, Biogeochemistry, 109, 49-61, https://doi.org/10.1007/s10533-011-9633-8, 2012.

Döös, B. R.: Population growth and loss of arable land, Global Environ. Chang., 12, 303-311, 2002.

Dou, J., Wang, Y., Bornstein, R., and Miao, S.: Observed spatial characteristics of Beijing urban climate impacts on summer thunderstorms, J. Appl. Meteorol. Clim., 54, 94-105, 2015.

Du, Y., Xie, Z., Zeng, Y., Yafeng, S., and Jingang, W.: Impact of urban expansion on regional temperature change in the Yangtze River Delta, J. Geogr. Sci., 17, 387-398, https://doi.org/10.1007/s11442-007-0387-0, 2007.

Eliasson, I.: Urban nocturnal temperatures, street geometry and land use, Atmos. Environ., 30, 379-392, 1996.

Ellis, E. C.: Anthropogenic transformation of the terrestrial biosphere, Philos. T. R. Soc. A, 369, 1010-1035, https://doi.org/10.1098/rsta.2010.0331, 2011.

Elmqvist, T. (Ed.): Urbanization, biodiversity and ecosystem services: challenges and opportunities: a global assessment; a part of the cities and biodiversity outlook project, Springer, Dordrecht, 2013.

Emmanuel, R. and Fernando, H. J. S.: Urban heat islands in humid and arid climates: role of urban form and thermal properties in Colombo, Sri Lanka and Phoenix, US, Clim. Res., 34, https://doi.org/10.3354/cr00694, 2007.

Erb, K.-H.: How a socio-ecological metabolism approach can help to advance our understanding of changes in land-use intensity, Ecol. Econ., 76, 8-14, https://doi.org/10.1016/j.ecolecon.2012.02.005, 2012.

Erb, K.-H., Gaube, V., Krausmann, F., Plutzar, C., Bondeau, A., and Haberl, H.: A comprehensive global 5 min resolution land-use data set for the year 2000 consistent with national census data, Journal of Land Use Science, 2, 191-224, https://doi.org/10.1080/17474230701622981, 2007.

Erb, K.-H., Krausmann, F., Lucht, W., and Haberl, H.: Embodied HANPP: Mapping the spatial disconnect between global biomass production and consumption, Ecol. Econ., 69, 328-334, https://doi.org/10.1016/j.ecolecon.2009.06.025, 2009.

Erb, K.-H., Haberl, H., Jepsen, M. R., Kuemmerle, T., Lindner, M., Müller, D., Verburg, P. H., and Reenberg, A. 
A conceptual framework for analysing and measuring land-use intensity, Curr. Opin. Env. Sust., 5, 464-470, https://doi.org/10.1016/j.cosust.2013.07.010, 2013.

Erb, K.-H., Fetzel, T., Haberl, H., Kastner, T., Kroisleitner, C., Lauk, C., Niedertscheider, M., and Plutzar, C.: Beyond Inputs and Outputs: Opening the Black-Box of Land-Use Intensity, in: Social Ecology: Society-Nature Relations across Time and Space, edited by: Haberl, H., Fischer-Kowalski, M., Krausmann, F., and Winiwarter, V., 93-124, Springer International Publishing, Cham., 2016.

Eriksson, E., Gillespie, A. R., Gustavsson, L., Langvall, O., Olsson, M., Sathre, R., and Stendahl, J.: Integrated carbon analysis of forest management practices and wood substitution, Can. J. Forest Res., 37, 671-681, 2007.

Erisman, J. W., Bleeker, A., Galloway, J. N., and Sutton, M. S.: Reduced nitrogen in ecology and the environment, Environ. Pollut., 150, 140-149, 2007.

Erisman, J. W., Bleeker, A., Hensen, A., and Vermeulen, A.: Agricultural air quality in Europe and the future perspectives, Atmos. Environ., 42, 3209-3217, https://doi.org/10.1016/j.atmosenv.2007.04.004, 2008.

Ermert, V., Fink, A. H., Morse, A. P., and Paeth, H.: The Impact of Regional Climate Change on Malaria Risk due to Greenhouse Forcing and Land-Use Changes in Tropical Africa, Environ. Health Persp., 120, 77-84, https://doi.org/10.1289/ehp.1103681, 2012.

Escobedo, F., Kroeger, T., and Wagner, J.: Urban forests and pollution mitigation: analyzing ecosystem services and disservices, Environ. Pollut., 159, 2078-2087, 2011.

Fahrig, L.: Effects of Habitat Fragmentation on Biodiversity, Annu. Rev. Ecol. Evol. S., 34, 487-515, https://doi.org/10.1146/annurev.ecolsys.34.011802.132419, 2003.

Feddema, J., Oleson, K., Bonan, G., Mearns, L., Washington, W., Meehl, G., and Nychka, D.: A comparison of a GCM response to historical anthropogenic land cover change and model sensitivity to uncertainty in present-day land cover representations, Clim. Dynam., 25, 581-609, https://doi.org/10.1007/s00382005-0038-z, 2005a.

Feddema, J. J., Oleson, K. W., Bonan, G. B., Mearns, L. O., Buja, L. E., Meehl, G. A., and Washington, W. M.: The importance of land-cover change in simulating future climates, Science, 310, 1674-1678, 2005b.

Feldpausch, T. R., Banin, L., Phillips, O. L., Baker, T. R., Lewis, S. L., Quesada, C. A., Affum-Baffoe, K., Arets, E. J. M. M., Berry, N. J., Bird, M., Brondizio, E. S., de Camargo, P., Chave, J., Djagbletey, G., Domingues, T. F., Drescher, M., Fearnside, P. M., França, M. B., Fyllas, N. M., Lopez-Gonzalez, G., Hladik, A., Higuchi, N., Hunter, M. O., Iida, Y., Salim, K. A., Kassim, A. R., Keller, M., Kemp, J., King, D. A., Lovett, J. C., Marimon, B. S., Marimon-Junior, B. H., Lenza, E., Marshall, A. R., Metcalfe, D. J., Mitchard, E. T. A., Moran, E. F., Nelson, B. W., Nilus, R., Nogueira, E. M., Palace, M., Patiño, S., Peh, K. S.-H., Raventos, M. T., Reitsma, J. M., Saiz, G., Schrodt, F., Sonké, B., Taedoumg, H. E., Tan, S., White, L., Wöll, H., and Lloyd, J.: Heightdiameter allometry of tropical forest trees, Biogeosciences, 8 , 1081-1106, https://doi.org/10.5194/bg-8-1081-2011, 2011.
Feyisa, G. L., Dons, K., and Meilby, H.: Efficiency of parks in mitigating urban heat island effect: An example from Addis Ababa, Landscape Urban Plan., 123, 87-95, 2014.

Fiore, A. M., Naik, V., Spracklen, D. V., Steiner, A., Unger, N., Prather, M., Bergmann, D., Cameron-Smith, P. J., Cionni, I., Collins, W. J., Dalsøren, S., Eyring, V., Folberth, G. A., Ginoux, P., Horowitz, L. W., Josse, B., Lamarque, J.-F., MacKenzie, I. A., Nagashima, T., O’Connor, F. M., Righi, M., Rumbold, S. T., Shindell, D. T., Skeie, R. B., Sudo, K., Szopa, S., Takemura, T., and Zeng, G.: Global air quality and climate, Chem. Soc. Rev., 41, 6663, https://doi.org/10.1039/c2cs35095e, 2012.

Firestone, M. K., Firestone, R. B., and Tiedje, J. M.: Nitrous Oxide from Soil Denitrification: Factors Controlling Its Biological Production, Science, 208, 749-751, https://doi.org/10.1126/science.208.4445.749, 1980.

Flechard, C. R., Neftel, A., Jocher, M., Ammann, C., and Fuhrer, J.: Bi-directional soil/atmosphere $\mathrm{N}_{2} \mathrm{O}$ exchange over two mown grassland systems with contrasting management practices, Glob. Change Biol., 11, 2114-2127, https://doi.org/10.1111/j.13652486.2005.01056.x, 2005.

Flynn, D. F. B., Gogol-Prokurat, M., Nogeire, T., Molinari, N., Richers, B. T., Lin, B. B., Simpson, N., Mayfield, M. M., and DeClerck, F.: Loss of functional diversity under land use intensification across multiple taxa, Ecol. Lett., 12, 22-33, https://doi.org/10.1111/j.1461-0248.2008.01255.x, 2009.

Foken, T.: Micrometeorology, Springer, Verlag Berlin Heidelberg, 2008.

Foley, J. A.: Global Consequences of Land Use, Science, 309, 570574, https://doi.org/10.1126/science.1111772, 2005.

Forzieri, G., Alkama, R., Miralles, D. G., and Cescatti, A.: Satellites reveal contrasting responses of regional climate to the widespread greening of Earth, Science, 356, 6343, 1180-1184, https://doi.org/10.1126/science.aal1727, 2017.

Fowler, D., Pilegaard, K., Sutton, M., Ambus, P., Raivonen, M., Duyzer, J., Simpson, D., Fagerli, H., Fuzzi, S., Schjoerring, J., Granier, C., Neftel, A., Isaksen, I., Laj, P., Maione, M., Monks, P., Burkhardt, J., Daemmgen, U., Neirynck, J., Personne, E., Wichink-Kruit, R., Butterbach-Bahl, K., Flechard, C., Tuovinen, J., Coyle, M., Gerosa, G., Loubet, B., Altimir, N., Gruenhage, L., Ammann, C., Cieslik, S., Paoletti, E., Mikkelsen, T., Ro-Poulsen, H., Cellier, P., Cape, J., Horvath, L., Loreto, F., Niinemets, U., Palmer, P., Rinne, J., Misztal, P., Nemitz, E., Nilsson, D., Pryor, S., Gallagher, M., Vesala, T., Skiba, U., Brueggemann, N., Zechmeister-Boltenstern, S., Williams, J., O’Dowd, C., Facchini, M., de Leeuw, G., Flossman, A., Chaumerliac, N., and Erisman, J.: Atmospheric composition change: Ecosystems-Atmosphere interactions, Atmos. Environ., 43, 5193-5267, https://doi.org/10.1016/j.atmosenv.2009.07.068, 2009 .

Fowler, D., Nemitz, E., Misztal, P., Di Marco, C., Skiba, U., Ryder, J., Helfter, C., Cape, J. N., Owen, S., Dorsey, J., Gallagher, M. W., Coyle, M., Phillips, G., Davison, B., Langford, B., MacKenzie, R., Muller, J., Siong, J., Dari-Salisburgo, C., Di Carlo, P., Aruffo, E., Giammaria, F., Pyle, J. A., and Hewitt, C. N.: Effects of land use on surface-atmosphere exchanges of trace gases and energy in Borneo: comparing fluxes over oil palm plantations and a rainforest, Philos. T. R. Soc. B, 366, 3196-3209, https://doi.org/10.1098/rstb.2011.0055, 2011. 
Fowler, D., Pyle, J. A., Raven, J. A., and Sutton, M. A.: The global nitrogen cycle in the twenty-first century: introduction, Philos. T. R. Soc. B, 368, 20130165, https://doi.org/10.1098/rstb.2013.0165, 2013.

Fujisaki, K., Perrin, A.-S., Desjardins, T., Bernoux, M., Balbino, L. C., and Brossard, M.: From forest to cropland and pasture systems: a critical review of soil organic carbon stocks changes in Amazonia, Glob. Change Biol., 21, 2773-2786, https://doi.org/10.1111/gcb.12906, 2015.

Furukawa, Y., Inubushi, K., Ali, M., Itang, A. M., and Tsuruta, H.: Effect of changing groundwater levels caused by land-use changes on greenhouse gas fluxes from tropical peat lands, Nutr. Cycl. Agroecosys., 71, 81-91, https://doi.org/10.1007/s10705004-5286-5, 2005.

Gaertner, M. A., Christensen, O. B., Prego, J. A., Polcher, J., Gallardo, C., and Castro, M.: The impact of deforestation on the hydrological cycle in the western Mediterranean: an ensemble study with two regional climate models, Clim. Dynam., 17, 857873,2001

Galloway, J. N., Aber, J. D., Erisman, J. W., Seitzinger, S. P., Howarth, R. W., Cowling, E. B., and Cosby, B. J.: The Nitrogen Cascade, BioScience, 53, 341-356, 2003.

Gálos, B., Hagemann, S., Hänsler, A., Kindermann, G., Rechid, D., Sieck, K., Teichmann, C., and Jacob, D.: Case study for the assessment of the biogeophysical effects of a potential afforestation in Europe, Carbon Balance and Management, 8, 3, https://doi.org/10.1186/1750-0680-8-3, 2013.

Ganzeveld, L. and Lelieveld, J.: Impact of Amazonian deforestation on atmospheric chemistry, Geophys. Res. Lett., 31, 6, https://doi.org/10.1029/2003GL019205, 2004.

Gentine, P., Holtslag, A. A., D'Andrea, F., and Ek, M.: Surface and atmospheric controls on the onset of moist convection over land, J. Hydrometeorol., 14, 1443-1462, 2013.

Georgescu, M., Mahalov, A., and Moustaoui, M.: Seasonal hydroclimatic impacts of Sun Corridor expansion, Environ. Res. Lett., 7, 034026, https://doi.org/10.1088/1748-9326/7/3/034026, 2012.

Georgescu, M., Morefield, P. E., Bierwagen, B. G., and Weaver, C. P.: Urban adaptation can roll back warming of emerging megapolitan regions, in P. Natl. Acad. Sci. USA, 111, 29092914, 2014.

Ghirardo, A., Xie, J., Zheng, X., Wang, Y., Grote, R., Block, K., Wildt, J., Mentel, T., Kiendler-Scharr, A., Hallquist, M., Butterbach-Bahl, K., and Schnitzler, J.-P.: Urban stressinduced biogenic VOC emissions and SOA-forming potentials in Beijing, Atmos. Chem. Phys., 16, 2901-2920, https://doi.org/10.5194/acp-16-2901-2016, 2016.

Gibbard, S., Caldeira, K., Bala, G., Phillips, T. J., and Wickett, M.: Climate effects of global land cover change, Geophys. Res. Lett., 32, 23705, https://doi.org/10.1029/2005GL024550, 2005.

Gillner, S., Bräuning, A., and Roloff, A.: Dendrochronological analysis of urban trees: climatic response and impact of drought on frequently used tree species, Trees, 28, 1079-1093, https://doi.org/10.1007/s00468-014-1019-9, 2014.

Ginet, P.: Le territoire, un concept opératoire pour la Géographie appliquée (à l'aménagement), Documentaliste - Sciences de l'Information, 49, 26-27, 2012.

Goldammer, J. G., Statheropoulos, M., and Andreae, M. O.: Impacts of vegetation fire emissions on the environment, human health, and security: a global perspective, in: Wildland fires and air pol- lution, edited by: Bytnerowicz, A., Arbaugh, M. J., Andersen, C., and Riebau, A. R., Elsevier Science, Amsterdam, the Netherlands, 2009.

Govindasamy, B., Duffy, P. B., and Caldeira, K.: Land use changes and Northern Hemisphere cooling, Geophys. Res. Lett., 28, 291294, 2001.

Gray, C. M., Monson, R. K., and Fierer, N.: Emissions of volatile organic compounds during the decomposition of plant litter, J. Geophys. Res., 115, G03015, https://doi.org/10.1029/2010JG001291, 2010.

Gregg, J. W., Jones, C. G., and Dawson, T. E.: Urbanization effects on tree growth in the vicinity of New York City, Nature, 424, 183-187, https://doi.org/10.1038/nature01728, 2003.

Grote, R., Samson, R., Alonso, R., Amorim, J. H., Cariñanos, P., Churkina, G., Fares, S., Thiec, D. L., Niinemets, Ü., Mikkelsen, T. N., Paoletti, E., Tiwary, A., and Calfapietra, C.: Functional traits of urban trees: air pollution mitigation potential, Front. Ecol. Environ., 14, 543-550, https://doi.org/10.1002/fee.1426, 2016.

Gruber, N. and Galloway, J. N.: An Earth-system perspective of the global nitrogen cycle, Nature, 451, 293-296, https://doi.org/10.1038/nature06592, 2008.

Guimarães, D. V., Gonzaga, M. I. S., da Silva, T. O., da Silva, T. L., da Silva Dias, N., and Matias, M. I. S.: Soil organic matter pools and carbon fractions in soil under different land uses, Soil Till Res., 126, 177-182, https://doi.org/10.1016/j.still.2012.07.010, 2013.

Haase, D., Frantzeskaki, N., and Elmqvist, T.: Ecosystem Services in Urban Landscapes: Practical Applications and Governance Implications, Ambio, 43, 407-412, https://doi.org/10.1007/s13280-014-0503-1, 2014.

Haberlie, A. M., Ashley, W. S., and Pingel, T. J.: The effect of urbanisation on the climatology of thunderstorm initiation: Urbanisation and Thunderstorm Initiation, Q. J. Roy. Meteor. Soc., 141, 663-675, https://doi.org/10.1002/qj.2499, 2015.

Hadfield, M. G., Cotton, W. R., and Pielke, R. A.: Large-eddy simulations of thermally forced circulations in the convective boundary layer. Part II: The effect of changes in wavelength and wind speed, Bound.-Lay. Meteorol., 58, 307-327, 1992.

Harper, K. L. and Unger, N.: Global climate forcing driven by altered BVOC fluxes from 1990 to 2010 land cover change in maritime Southeast Asia, Atmos. Chem. Phys., 18, 16931-16952, https://doi.org/10.5194/acp-18-16931-2018, 2018.

Hart, M. A. and Sailor, J. D.: Quantifying the influence of land-use and surface characteristics on spatial variability in the urban heat island, Theor. Appl. Climatol., 95, 397-406, 2009.

Hastings, A.: Transients: the key to long-term ecological understanding?, Trends Ecol. Evol., 19, 39-45, https://doi.org/10.1016/j.tree.2003.09.007, 2004.

Hati, K. M., Swarup, A., Mishra, B., Manna, M. C., Wanjari, R. H., Mandal, K. G., and Misra, A. K.: Impact of long-term application of fertilizer, manure and lime under intensive cropping on physical properties and organic carbon content of an Alfisol, Geoderma, 148, 173-179, https://doi.org/10.1016/j.geoderma.2008.09.015, 2008.

Heald, C. L. and Spracklen, D. V.: Land Use Change Impacts on Air Quality and Climate, Chem. Rev., 115, 4476-4496, https://doi.org/10.1021/cr500446g, 2015. 
Heald, C. L., Henze, D. K., Horowitz, L. W., Feddema, J., Lamarque, J.-F., Guenther, A., Hess, P. G., Vitt, F., Seinfeld, J., Goldstein, A. H., and Fung, I.: Predicted change in global secondary organic aerosol concentrations in response to future climate, emissions, and land use change, J. Geophys. Res.-Atmos., 113, D05211, https://doi.org/10.1029/2007JD009092, 2008.

Heaviside, C., Cai, X. M., and Vardoulakis, S.: The effects of horizontal advection on the urban heat island in Birmingham and the West Midlands, United Kingdom during a heatwave, Q. J. Roy. Meteor. Soc., 141, 1429-1441, https://doi.org/10.1002/qj.2452, 2015.

Heck, P., Luthi, D., Wernli, H., and Schar, C.: Climate impacts of European-scale anthropogenic vegetation changes: A sensitivity study using a regional climate model, J. Geophys. Res.-Atmos., 106, 7817-7835, https://doi.org/10.1029/2000jd900673, 2001.

Hewitt, C. N., Mackenzie, R., Di Carlo, P., Di Marco, C. F., Dorsey, J. R., Evans, M., Fowler, D., Gallagher, M. W., Hopkins, J. R., Jones, C. E., Langford, B., Lee, J. D., Lewis, A. C., Lim, S. F., McQuaid, J., Misztal, P., Moller, S. J., Monks, P. S., Nemitz, E., Oram, D. E., Owen, S. M., Phillips, G. J., Pugh, T., Pyle, J. A., Reeves, C. E., Ryder, J., Siong, J., Skiba, U., and Stewart, D. $\mathrm{J} .:$ Nitrogen management is essential to prevent tropical oil palm plantations from causing ground-level ozone pollution, in P. Natl. Acad. Sci. USA, 106, 18447-18451, 2009.

Higgins, S. I.: Ecosystem Assembly: A Mission for Terrestrial Earth System Science, Ecosystems, 20, 69-77, https://doi.org/10.1007/s10021-016-0054-3, 2017.

Hill, A. C.: Vegetation: A Sink for Atmospheric Pollutants, JAPCA J. Air Waste Ma., 21, 341-346, 1971.

Hole, D. G., Perkins, A. J., Wilson, J. D., Alexander, I. H., Grice, P. V., and Evans, A. D.: Does organic farming benefit biodiversity?, Biol. Conserv., 122, 113-130, https://doi.org/10.1016/j.biocon.2004.07.018, 2005.

Hooijer, A., Silvius, M., Wosten, H., and Page, S.: PEAT-CO2, Assessment of $\mathrm{CO}_{2}$ emissions from drained peatlands in SE Asia, Delft Hydraulics report Q3943/2006, 36 pp., available at: http://peat-co2.deltares.nl (last access: 28 May 2019), 2006.

Hooke, R. L. and Martin-Duque, J. F.: Land transformation by humans: a review, GSA Today, 22, 4-10, 2012.

Houghton, R. A., Boone, R. D., Melillo, J. M., Palm, C. A., Woodwell, G. M., Moore, B., and Skole, D. L.: Net flux of $\mathrm{CO}_{2}$ from tropical forests, Nature, 316, 617-620, 1985.

Houghton, R. A., Boone, R. D., Fruci, J. R., Hobbie, J. E., Melillo, J. M., Palm, C. A., Peterson, B. J., Shaver, G. R., Woodwell, G. M., Moore, B., and Skole, D. L.: The flux of carbon from terrestrial ecosystems to the atmosphere in 1980 due to changes in land use: Geographic distribution of the global flux, Tellus, 39, 122-139, 1987.

Houghton, R. A., House, J. I., Pongratz, J., van der Werf, G. R., DeFries, R. S., Hansen, M. C., Le Quéré, C., and Ramankutty, $\mathrm{N}$.: Carbon emissions from land use and land-cover change, Biogeosciences, 9, 5125-5142, https://doi.org/10.5194/bg-9-51252012, 2012.

Houspanossian, J., Giménez, R., Jobbágy, E., and Nosetto, M.: Surface albedo raise in the South American Chaco: Combined effects of deforestation and agricultural changes, Agr. Forest Meteorol., 232, 118-127, 2017.

Hu, D., Bian, Q., Li, T. W. Y., Lau, A. K. H., and Yu, J. Z.: Contributions of isoprene, monoterpenes, $\beta$-caryophyllene, and toluene to secondary organic aerosols in Hong Kong during the summer of 2006, J. Geophys. Res., 113, D22206, https://doi.org/10.1029/2008JD010437, 2008.

Hu, S., Chapin, F. S., Firestone, M. K., Field, C. B., and Chiariello, N. R.: Nitrogen limitation of microbial decomposition in a grassland under elevated $\mathrm{CO}_{2}$, Nature, 409, 188-191, 2001.

Immirzi, C. P., Maltby, E., and Clymo, R. S.: The global status of peatlands and their role in carbon cycling: a report for Friends of the Earth, Friends of the Earth, London, 1992.

Jackson, R. B., Randerson, J. T., Canadell, J. G., Anderson, R. G., Avissar, R., Baldocchi, D. D., Bonan, G. B., Caldeira, K., Diffenbaugh, N. S., Field, C. B., Hungtae, B. A., Jobbagy, E. G., Kueppers, L. M., Nosetto, M. D., and Pataki, D. E.: Protecting climate with forests, Environ. Res. Lett., 3, 044006, https://doi.org/10.1088/1748-9326/3/4/044006, 2008.

Jackson, R. B., Cook, C. W., Pippen, J. S., and Palmer, S. M.: Increased belowground biomass and soil $\mathrm{CO}_{2}$ fluxes after a decade of carbon dioxide enrichment in a warm-temperate forest, Ecology, 90, 3352-3366, https://doi.org/10.1890/08-1609.1, 2009.

Jacobson, M. Z., Nghiem, S. V., and Sorichetta, A.: Short-term impacts of the mega-urbanizations of New Delhi and Los Angeles between 2000 and 2009, J. Geophys Res., 124, 35-56, 2019.

Jagger, P. and Shively, G.: Land use change, fuel use and respiratory health in Uganda, Energ. Policy, 67, 713-726, https://doi.org/10.1016/j.enpol.2013.11.068, 2014.

Jain, A. K., Meiyappan, P., and Song, Y.: $\mathrm{CO}_{2}$ emissions from land-use change affected more by nitrogen cycle, than by the choice of land-cover data, Glob. Change Biol., 19, 2893-2906, https://doi.org/10.1111/gcb.12207, 2013.

Jang, M., Cao, G., and Paul, J.: Colorimetric Particle Acidity Analysis of Secondary Organic Aerosol Coating on Submicron Acidic Aerosols, Aerosol Sci. Tech., 42, 409-420, https://doi.org/10.1080/02786820802154861, 2008.

Janhäll, S.: Review on urban vegetation and particle air pollution deposition and dispersion, Atmos. Environ., 105, 130-137, 2015.

Jauhiainen, J., Silvennoinen, H., Könönen, M., Limin, S., and Vasander, H.: Management driven changes in carbon mineralization dynamics of tropical peat, Biogeochemistry, 129, 115-132, https://doi.org/10.1007/s10533-016-0222-8, 2016.

Jauregui, E. and Luyando, E.: Global radiation attenuation by air pollution and its effects on the thermal climate in Mexico City, Int. J. Climatol., 19, 683-694, 1999.

Jiang, X., Wiedinmyer, C., Chen, F., Yang, Z.-L., and Lo, C. F.: Predicted impacts of climate and land use change on surface ozone in the Houston, Texas, area, J. Geophys. Res., 113, 20312, https://doi.org/10.1029/2008JD009820, 2008.

Joergensen, R. G., Mäder, P., and Fließbach, A.: Long-term effects of organic farming on fungal and bacterial residues in relation to microbial energy metabolism, Biol. Fert. Soils, 46, 303-307, https://doi.org/10.1007/s00374-009-0433-4, 2010.

Jones, C. G., Lawton, J. H., and Shachak, M.: Organisms as Ecosystem Engineers, Oikos, 69, 373, https://doi.org/10.2307/3545850, 1994.

Jones, R., Patwardhan, A., Cohen, S., Dessai, S., Lammel, A., Lempert, R., Mirza, M., and von Storch, H.: Foundations for decision making, in: Climate change 2014: impacts, adaptation, and vulnerability. Part A: global and sectoral aspects, Contribution of Working Group II to the Fifth Assessment Report of the Intergovernmental Panel on Climate Change, edited by: Field, C. B., 
Barros, V. R., Dokken, D. J., Mach, K. J., Mastrandrea, M. D., Bilir, T. E., Chatterjee, M., Ebi, K. L., Estrada, Y. O., Genova, R. C., Girma, B., Kissel, E. S., Levy, A. N., MacCracken, S., Mastrandrea, P. R., and White, L. L., 195-228, Cambridge and New York, 2014.

Jost, C., Trentmann, J., Sprung, D., Andreae, M. O., McQuaid, J. B., and Barjat, H.: Trace gas chemistry in a young biomass burning plume over Namibia: Observations and model simulations, J. Geophys. Res.-Atmos., 108, 8482, https://doi.org/10.1029/2002JD002431, 2003.

Ju, X.-T., Xing, G.-X., Chen, X.-P., Zhang, S.-L., Zhang, L.-J., Liu, X.-J., Cui, Z.-L., Yin, B., Christie, P., Zhu, Z.-L., and Zhang, F.S.: Reducing environmental risk by improving $\mathrm{N}$ management in intensive Chinese agricultural systems, P. Natl. Acad. Sci. USA, 106, 3041-3046, doi.org/10.1073/pnas.0813417106, 2009.

Kasimir-Klemedtsson, Å., Klemedtsson, L., Berglund, K., Martikainen, P., Silvola, J., and Oenema, O.: Greenhouse gas emissions from farmed organic soils: a review, Soil Use Manage., 13, 245-250, https://doi.org/10.1111/j.1475-2743.1997.tb00595.x, 1997.

Kato, S. and Yamaguchi, Y.: Analysis of urban heat-island effect using ASTER and ETM+ data: separation of anthropogenic heat discharge and natural heat radiation from sensible heat flux, Remote. Sens. Environ., 99, 44-54, 2005.

Kellner, O. and Niyogi, D.: Land Surface Heterogeneity Signature in Tornado Climatology? An Illustrative Analysis over Indiana, 1950-2012*, Earth Interact., 18, 1-32, https://doi.org/10.1175/2013EI000548.1, 2014.

Kim, J. J. and Baik, J. J.: A numerical study of thermal effects on flow and pollutant dispersion in urban street canyons, J. Appl. Meteorol., 38, 1249-1261, 1999.

Kim, Y. H. and Baik, J. J.: Maximum urban heat island intensity in Seoul, J. Appl. Meteorol., 41, 651-659, 2002.

Klein Goldewijk, K.: Estimating Global Land Use Change over the Past 300 Years: The HYDE Database, Global Biogeochem. Cy., 15, 417-433, 2001.

Klein Goldewijk, K.: The HYDE 3.1 spatially explicit database of human-induced global land-use change over the past 12,000 years, Global Ecol. Biogeogr., 20, 73-86, 2011.

Klemm, O. and Mangold, A.: Ozone Deposition at a Forest Site in NE Bavaria, Water Air Soil Poll., 1, 223-232, https://doi.org/10.1023/A:1013167408114, 2001.

Krebs, J. R., Wilson, J. D., Bradbury, R. B., and Siriwardena, G. M.: The second silent spring?, Nature, 400, 611-612, 1999.

Kueppers, L. M. and Snyder, M. A.: Influence of irrigated agriculture on diurnal surface energy and water fluxes, surface climate, and atmospheric circulation in California, Clim. Dynam., 38, 1017-1029, https://doi.org/10.1007/s00382-011-1123-0, 2012.

Kueppers, L. M., Snyder, M. A., and Sloan, L. C.: Irrigation cooling effect: Regional climate forcing by land-use change, Geophys. Res. Lett., 34, 03703, https://doi.org/10.1029/2006gl028679, 2007.

Kumar, R. and Kaushik, S. C.: Performance evaluation of green roof and shading for thermal protection of buildings, Build. Environ., 40, 1505-1511, 2005.

Lai, L.-W. and Cheng, W.-L.: Air quality influenced by urban heat island coupled with synoptic weather patterns, Sci. Total Environ., 407, 2724-2733, https://doi.org/10.1016/j.scitotenv.2008.12.002, 2009.
Lal, R.: Soil Carbon Sequestration Impacts on Global Climate Change and Food Security, Science, 304, 1623-1627, https://doi.org/10.1126/science.1097396, 2004.

Lambin, E. F. and Geist, H.: Introduction: local processes with global impacts, edited by: Lambin, E. F. and Geist, H., Springer Verlag, Berlin Heidelberg, 2006.

Lambin, E. F., Turner, B. L., Geist, H. J., Agbola, S. B., Angelsen, A., Bruce, J. W., Coomes, O. T., Dirzo, R., Fischer, G., Folke, C., George, P. S., Homewood, K., Imbernon, J., Leemans, R., Li, X., Moran, E. F., Mortimore, M., Ramakrishnan, P. S., Richards, J. F., Skånes, H., Steffen, W., Stone, G. D., Svedin, U., Veldkamp, T. A., Vogel, C., and Xu, J.: The causes of landuse and land-cover change: moving beyond the myths, Global Environ. Chang., 11, 261-269, https://doi.org/10.1016/S09593780(01)00007-3, 2001.

Lammel, D. R., Feigl, B. J., Cerri, C. C., and Nüsslein, K.: Specific microbial gene abundances and soil parameters contribute to $\mathrm{C}, \mathrm{N}$, and greenhouse gas process rates after land use change in Southern Amazonian Soils, Front. Microbiol., 6, p. 1057, https://doi.org/10.3389/fmicb.2015.01057, 2015.

Lapola, D. M., Oyama, M. D., and Nobre, C. A.: Exploring the range of climate biome projections for tropical South America: The role of $\mathrm{CO}_{2}$ fertilization and seasonality, Global Biogeochem. Cy., 23, GB3003, https://doi.org/10.1029/2008GB003357, 2009.

Lathière, J., Hauglustaine, D. A., Friend, A. D., De NobletDucoudré, N., Viovy, N., and Folberth, G. A.: Impact of climate variability and land use changes on global biogenic volatile organic compound emissions, Atmos. Chem. Phys., 6, 2129-2146, https://doi.org/10.5194/acp-6-2129-2006, 2006.

Lean, J. and Rowntree, R. P.: Understanding the sensitivity of a GCM simulation of Amazonian deforestation to the specification of vegetation and soil characteristics, J. Climate, 10, 1216-1235, 1997.

Le Berre, M.: Territoires, Encyclopédie de Géographie, Economica, Paris, 601-622, 1992.

Lejeune, Q., Davin, E. L., Guillod, B. P., and Seneviratne, S. I.: Influence of Amazonian deforestation on the future evolution of regional surface fluxes, circulation, surface temperature and precipitation, Clim. Dynam., 44, 2769-2786, https://doi.org/10.1007/s00382-014-2203-8, 2015.

Lejeune, Q., Davin, E. L., Gudmundsson, L., Winckler, J., and Seneviratne, S. I.: Historical deforestation locally increased the intensity of hot days in northern mid-latitudes, Nat. Clim. Change, 8, 386-390, https://doi.org/10.1038/s41558-018-0131z, 2018.

Le Quéré, C., Andres, R. J., Boden, T., Conway, T., Houghton, R. A., House, J. I., Marland, G., Peters, G. P., van der Werf, G. R., Ahlström, A., Andrew, R. M., Bopp, L., Canadell, J. G., Ciais, P., Doney, S. C., Enright, C., Friedlingstein, P., Huntingford, C., Jain, A. K., Jourdain, C., Kato, E., Keeling, R. F., Klein Goldewijk, K., Levis, S., Levy, P., Lomas, M., Poulter, B., Raupach, M. R., Schwinger, J., Sitch, S., Stocker, B. D., Viovy, N., Zaehle, S., and Zeng, N.: The global carbon budget 1959-2011, Earth Syst. Sci. Data, 5, 165-185, https://doi.org/10.5194/essd-5-1652013, 2013.

Le Quéré, C., Andrew, R. M., Friedlingstein, P., Sitch, S., Hauck, J., Pongratz, J., Pickers, P. A., Korsbakken, J. I., Peters, G. P., Canadell, J. G., Arneth, A., Arora, V. K., Barbero, L., Bastos, 
A., Bopp, L., Chevallier, F., Chini, L. P., Ciais, P., Doney, S. C., Gkritzalis, T., Goll, D. S., Harris, I., Haverd, V., Hoffman, F. M., Hoppema, M., Houghton, R. A., Hurtt, G., Ilyina, T., Jain, A. K., Johannessen, T., Jones, C. D., Kato, E., Keeling, R. F., Goldewijk, K. K., Landschützer, P., Lefèvre, N., Lienert, S., Liu, Z., Lombardozzi, D., Metzl, N., Munro, D. R., Nabel, J. E. M. S., Nakaoka, S.-I., Neill, C., Olsen, A., Ono, T., Patra, P., Peregon, A., Peters, W., Peylin, P., Pfeil, B., Pierrot, D., Poulter, B., Rehder, G., Resplandy, L., Robertson, E., Rocher, M., Rödenbeck, C., Schuster, U., Schwinger, J., Séférian, R., Skjelvan, I., Steinhoff, T., Sutton, A., Tans, P. P., Tian, H., Tilbrook, B., Tubiello, F. N., van der Laan-Luijkx, I. T., van der Werf, G. R., Viovy, N., Walker, A. P., Wiltshire, A. J., Wright, R., Zaehle, S., and Zheng, B.: Global Carbon Budget 2018, Earth Syst. Sci. Data, 10, 21412194, https://doi.org/10.5194/essd-10-2141-2018, 2018.

Li, H., Harvey, J., and Kendall, A.: Field measurement of albedo for different land cover materials and effect on thermal performance, Build. Environ., 59, 536-546, 2013.

Li, H., Meier, F., Lee, X., Chakraborty, T., Liu, J., Schaap, M., and Sodoudi, S.: Interaction between urban heat island and urban pollution island during summer in Berlin, Sci. Total Environ., 636, 818-828, https://doi.org/10.1016/j.scitotenv.2018.04.254, 2018.

Li, J., Mahalov, A., and Hyde, P.: Impacts of agricultural irrigation on ozone concentrations in the Central Valley of California and in the contiguous United States based on WRF-Chem simulations, Agr. Forest Meteorol., 221, 34-49, https://doi.org/10.1016/j.agrformet.2016.02.004, 2016.

Li, Y., Zhao, M., Motesharrei, S., Mu, Q., Kalnay, E., and $\mathrm{Li}, \mathrm{S}$.: Local cooling and warming effects of forests based on satellite observations, Nat. Commun., 6, 6603, https://doi.org/10.1038/ncomms7603, 2015.

Lindenmayer, D., Cunningham, S., and Young, A.: Land Use Intensification: Effects on Agriculture, Biodiversity and Ecological Processes, Perspectives on land use intensification and biodiversity conservation, 137-149, Lindenmayer David, Cunningham Saul and AndrewYoung, Collingwood, Australia, https://doi.org/10.1111/aec.12174, 2012.

Liu, C., Holst, J., Brüggemann, N., Butterbach-Bahl, K., Yao, Z., Han, S., Han, X., and Zheng, X.: Effects of irrigation on nitrous oxide, methane and carbon dioxide fluxes in an Inner Mongolian steppe, Adv. Atmos. Sci., 25, 748-756, https://doi.org/10.1007/s00376-008-0748-3, 2008.

Livesley, S. J., McPherson, E. G., and Calfapietra, C.: The Urban Forest and Ecosystem Services: Impacts on Urban Water, Heat, and Pollution Cycles at the Tree, Street, and City Scale, J. Environ. Qual., 45, 119-124, https://doi.org/10.2134/jeq2015.11.0567, 2016.

Llopart, M., Reboita, M., Coppola, E., Giorgi, F., da Rocha, R., and de Souza, D.: Land Use Change over the Amazon Forest and Its Impact on the Local Climate, Water, 10, 149, https://doi.org/10.3390/w10020149, 2018.

Lobell, D. B. and Bonfils, C.: The Effect of Irrigation on Regional Temperatures: A Spatial and Temporal Analysis of Trends in California, 1934-2002, J. Climate, 21, 2063-2071, https://doi.org/10.1175/2007JCLI1755.1, 2008.

Lobell, D. B., Bala, G., and Duffy, P. B.: Biogeophysical impacts of cropland management changes on climate, Geophys. Res. Lett., 33, L06708, https://doi.org/10.1029/2005GL025492, 2006.
Lobell, D. B., Bonfils, C., and Duffy, P. B.: Climate change uncertainty for daily minimum and maximum temperatures: a model inter-comparison, Geophys. Res. Lett., 34, L05715, https://doi.org/10.1029/2006GL028726, 2007.

López, M. V., Gracia, R., and Arrué, J. L.: Effects of reduced tillage on soil surface properties affecting wind erosion in semiarid fallow lands of Central Aragon, Eur. J. Agron., 12, 191-199, 2000.

López, M. V., de Dios Herrero, J. M., Hevia, G. G., Gracia, R., and Buschiazzo, D. E.: Determination of the wind-erodible fraction of soils using different methodologies, Geoderma, 139, 407-411, https://doi.org/10.1016/j.geoderma.2007.03.006, 2007.

Loreau, M., Naeem, S., and Inchausti, P. (Eds.): Biodiversity and ecosystem functioning: synthesis and perspectives, Oxford University Press, Oxford, 2002.

Lorenz, J. M., Kronenberg, R., Bernhofer, C., and Niyogi, D.: Urban Rainfall Modification: Observational Climatology Over Berlin, Germany, J. Geophys. Res.-Atmos., 124, 731-746, https://doi.org/10.1029/2018JD028858, 2019.

Luyssaert, S., Jammet, M., Stoy, P. C., Estel, S., Pongratz, J., Ceschia, E., Churkina, G., Don, A., Erb, K., Ferlicoq, M., and Gielen, B.: Land management and land-cover change have impacts of similar magnitude on surface temperature, Nat. Clim. Change, 4, 389-393, 2014.

MacIvor, J. S. and Lundholm, J.: Performance evaluation of native plants suited to extensive green roof conditions in a maritime climate, Ecol. Eng., 37, 407-417, 2011.

MacKenzie, A. R., Harrison, R. M., Colbeck, I., Clark, P. A., and Varey, R. H.: The ozone increments in urban plumes, Sci. Total Environ., 159, 91-99, https://doi.org/10.1016/00489697(95)04312-O, 1995.

Magnani, F., Mencuccini, M., Borghetti, M., Berbigier, P., Berninger, F., Delzon, S., Grelle, A., Hari, P., Jarvis, P. G., Kolari, P., Kowalski, A. S., Lankreijer, H., Law, B. E., Lindroth, A., Loustau, D., Manca, G., Moncrieff, J. B., Rayment, M., Tedeschi, V., Valentini, R., and Grace, J.: The human footprint in the carbon cycle of temperate and boreal forests, Nature, 447, 849-851, https://doi.org/10.1038/nature05847, 2007.

Mahfouf, J. F., Richard, E., and Mascart, P.: The influence of soil and vegetation on the development of mesoscale circulations, J. Clim. Appl. Meteorol., 26, 1483-1495, 1987.

Mahmood, R., Pielke, R. A., Hubbard, K. G., Niyogi, D., Dirmeyer, P. A., McAlpine, C., Carleton, A. M., Hale, R., Gameda, S., Beltrán-Przekurat, A., Baker, B., McNider, R., Legates, D. R., Shepherd, M., Du, J., Blanken, P. D., Frauenfeld, O. W., Nair, U. S., and Fall, S.: Land cover changes and their biogeophysical effects on climate: Land cover changes and their biogeophysical effects on cliamte, Int. J. Climatol., 34, 929-953, https://doi.org/10.1002/joc.3736, 2014.

Mahrt, L. and Ek, M.: Spatial variability of turbulent fluxes and roughness lengths in HAPEX-MOBILHY, Bound.-Lay. Meteorol., 65, 381-400, 1993.

Mahrt, L., Sun, J., Vickers, D., MacPherson, J. I., Pederson, J. R., and Desjardins, R. L.: Observations of fluxes and inland breezes over a heterogeneous surface, J. Atmos. Sci., 51, 2484-2499, 1994.

Maljanen, M., Sigurdsson, B. D., Guðmundsson, J., Óskarsson, H., Huttunen, J. T., and Martikainen, P. J.: Greenhouse gas balances of managed peatlands in the Nordic countries - 
present knowledge and gaps, Biogeosciences, 7, 2711-2738, https://doi.org/10.5194/bg-7-2711-2010, 2010.

Maltby, E. and Immirzi, P.: Carbon dynamics in peatlands and other wetland soils: regional and global perspectives, Chemosphere, 27, 999-1023, 1993.

Manzoni, S., Taylor, P., Richter, A., Porporato, A., and Ågren, G. I.: Environmental and stoichiometric controls on microbial carbonuse efficiency in soils: Research review, New Phytol., 196, 7991, https://doi.org/10.1111/j.1469-8137.2012.04225.x, 2012.

Markvart, T., Castañer, L., and Castaner, L. (Eds.): Practical Handbook of Photovoltaics: Fundamentals and Applications, Elsevier, 2003.

Marschner, P.: Structure and function of the soil microbial community in a long-term fertilizer experiment, Soil Biol. Biochem., 35, 453-461, https://doi.org/10.1016/S0038-0717(02)00297-3, 2003.

Marshall, C. H., Pielke, R. A., and Steyaert, L. T.: Has the conversion of natural wetlands to agricultural land increased the incidence and severity of damaging freezes in south Florida?, Mon. Weather Rev., 132, 2243-2258, https://doi.org/10.1175/15200493(2004)132<2243:HTCONW>2.0.CO;2, 2004a.

Marshall, C. H., Pielke, R. A., Steyaert, L. T., and Willard, D. A.: The impact of anthropogenic land-cover change on the Florida peninsula sea breezes and warm season sensible weather, Mon. Weather Rev., 132, 28-52, https://doi.org/10.1175/15200493(2004)132<0028:Tioalc >2.0.Co;2, 2004b.

Mason, S. A., Trentmann, J., Winterrath, T., Yokelson, R. J., Christian, T. J., Carlson, L. J., Warner, T. R., Wolfe, L. C., and Andreae, M. O.: Intercomparison of two box models of the chemical evolution in biomass-burning smoke plumes, J. Atmos. Chem., 55, 273-297, 2006.

Mataix-Solera, J., Cerdà, A., Arcenegui, V., Jordán, A., and Zavala, L. M.: Fire effects on soil aggregation: A review, Earth-Sci. Rev., 109, 44-60, https://doi.org/10.1016/j.earscirev.2011.08.002, 2011.

Matson, P. A., Parton, W. J., Power, A. G., and Swift, M. J.: Agricultural intensification and ecosystem properties, Science, 25, 504509, 1997.

Matthews, H. D., Weaver, A. J., Eby, M., and Meissner, K. J.: Radiative forcing of climate by historical land cover change, Geophys. Res. Lett., 30, 1055, https://doi.org/10.1029/2002GL016098, 2003.

Matson, P. A., Parton, W. J., Power, A. G., and Swift, M. J.: Agricultural intensification and ecosystem properties, Science, 25, 504509, 1997.

Medlyn, B. E., Zaehle, S., De Kauwe, M. G., Walker, A. P., Dietze, M. C., Hanson, P. J., Hickler, T., Jain, A. K., Luo, Y., Parton, W., Prentice, I. C., Thornton, P. E., Wang, S., Wang, Y.-P., Weng, E., Iversen, C. M., McCarthy, H. R., Warren, J. M., Oren, R., and Norby, R. J.: Using ecosystem experiments to improve vegetation models, Nat. Clim. Change, 5, 528-534, https://doi.org/10.1038/nclimate2621, 2015.

Meissner, K. J., Weaver, A. J., Matthews, H. D., and Cox, P. M.: The role of land surface dynamics in glacial inception: a study with the UVic Earth System Model, Clim. Dynam., 21, 515-537, 2003.

Menalled, F. D., Costamagna, A. C., Marino, P. C., and Landis, D. A.: Temporal variation in the response of parasitoids to agri- cultural landscape structure, Agr. Ecosyst. Environ., 96, 29-35, https://doi.org/10.1016/S0167-8809(03)00018-5, 2003.

Meyer, S., Bright, R. M., Fischer, D., Schulz, H., and Glaser, B.: Albedo Impact on the Suitability of Biochar Systems To Mitigate Global Warming, Environ. Sci. Technol., 46, 12726-12734, https://doi.org/10.1021/es302302g, 2012.

Middel, A., Häb, K., Brazel, A. J., Martin, C. A., and Guhathakurta, S.: Impact of urban form and design on mid-afternoon microclimate in Phoenix Local Climate Zones, Landscape Urban Plan., 122, 16-28, 2014.

Millstein, D. and Menon, S.: Regional climate consequences of large-scale cool roof and photovoltaic array deployment, Environ. Res. Lett., 6, 034001, https://doi.org/10.1088/17489326/6/3/034001, 2011.

Mimet, A., Pellissier, V., Quénol, H., Aguejdad, R., Dubreuil, V., and Rozé, F.: Urbanisation induces early flowering: evidence from Platanus acerifolia and Prunus cerasus, Int. J. Biometeorol., 53, 287-298, https://doi.org/10.1007/s00484-009-0214-7, 2009.

Mladenoff, D. J.: Dynamics of Nitrogen Mineralization and Nitrification in Hemlock and Hardwood Treefall Gaps, Ecology, 68, 1171-1180, https://doi.org/10.2307/1939201, 1987.

Mohamed, Y. A., Van den Hurk, B. J. J. M., Savenije, H. H. G., and Bastiaanssen, W. G. M.: Impact of the Sudd wetland on the Nile hydroclimatology, Water Resour. Res., 41, 8420, https://doi.org/10.1029/2004WR003792, 2005.

Moller, H., MacLeod, C. J., Haggerty, J., Rosin, C., Blackwell, G., Perley, C., Meadows, S., Weller, F., and Gradwohl, M.: Intensification of New Zealand agriculture: Implications for biodiversity, New Zeal. J. Agr. Res., 51, 253-263, https://doi.org/10.1080/00288230809510453, 2008.

Montgomery, D. R.: Soil erosion and agricultural sustainability, P. Natl. Acad. Sci. USA, 104, 13268-13272, https://doi.org/10.1073/pnas.0611508104, 2007.

Murugan, R. and Kumar, S.: Influence of long-term fertilisation and crop rotation on changes in fungal and bacterial residues in a tropical rice-field soil, Biol. Fert. Soils, 49, 847-856, https://doi.org/10.1007/s00374-013-0779-5, 2013.

Muscolo, A., Bagnato, S., Sidari, M., and Mercurio, R.: A review of the roles of forest canopy gaps, J. Forest. Res., 25, 725-736, 2014.

Nair, U. S., Lawton, R. O., Welch, R. M., and Pielke, R. A.: Impact of land use on Costa Rican tropical montane cloud forests: Sensitivity of cumulus cloud field characteristics to lowland deforestation, J. Geophys. Res.-Atmos., 108, 4206, https://doi.org/10.1029/2001JD001135, 2003.

Naudts, K., Chen, Y., McGrath, M. J., Ryder, J., Valade, A., Otto, J., and Luyssaert, S.: Europe's forest management did not mitigate climate warming, Science, 351, 597-600, 2016.

Neill, C., Steudler, P. A., Garcia-Montiel, D. C., Melillo, J. M., Feigl, B. J., Piccolo, M. C., and Cerri, C. C.: Rates and controls of nitrous oxide and nitric oxide emissions following conversion of forest to pasture in Rondônia, Nutr. Cycl. Agroecosys., 71, $1-15,2005$.

Nogherotto, R., Coppola, E., Giorgi, F., and Mariotti, L.: Impact of Congo Basin deforestation on the African monsoon: Impact of Congo Basin deforestation, Atmos. Sci. Lett., 14, 45-51, https://doi.org/10.1002/as12.416, 2013.

Norby, R. J., De Kauwe, M. G., Domingues, T. F., Duursma, R. A., Ellsworth, D. S., Goll, D. S., Lapola, D. M., Luus, K. A., 
MacKenzie, A. R., Medlyn, B. E., Pavlick, R., Rammig, A., Smith, B., Thomas, R., Thonicke, K., Walker, A. P., Yang, X., and Zaehle, S.: Model-data synthesis for the next generation of forest free-air $\mathrm{CO}_{2}$ enrichment (FACE) experiments, New Phytol., 209, 17-28, https://doi.org/10.1111/nph.13593, 2016.

Novak, D. J., Crane, D. E., and Stevens, J. C.: Air pollution removal by urban trees and shrubs, Urban Forestry and Urban Greening, 4, 115-123, 2006.

Nowak, D. J., Civerolo, K. L., Rao, S. T., Sistla, G., Luley, C. J., and Crane, D. E.: A modeling study of the impact of urban trees on ozone, Atmos. Environ., 34, 1601-1613, 2000.

Oberndorfer, E., Lundholm, J., Bass, B., Coffman, R. R., Doshi, H., Dunnett, N., Gafin, S., Köhler, M., Liu, K. K. Y., and Rowe, B.: Green roofs as urban ecosystems: ecological structures, functions, and services, BioScience, 57, 823-833, 2007.

Oke, T. R.: The energetic basis of the urban heat island, Q. J. Roy. Meteor. Soc., 108, 1-24, 1982.

Oke, T. R. and Fuggle, F. R.: Comparison of urban/rural counter and net radiation at night, Bound.-Lay. Meteorol., 2, 290-308, 1972.

Ooi, M. C. G., Chan, A., Ashfold, M. J., Oozeer, M. Y., Morris, K. I., and Kong, S. S. K.: The role of land use on the local climate and air quality during calm intermonsoon in a tropical city, Geosci. Front., 10, 405-415, https://doi.org/10.1016/j.gsf.2018.04.005, 2019.

Otterman, J.: Baring high-albedo soils by over grazing: A hypothesized desertification method, Science, 186, 531-533, 1974.

Pearlmutter, D., Bitan, A., and Berliner, P.: Microclimatic analysis of "compact" urban canyons in an arid zone, Atmos. Environ., 33, 4143-4150, 1999.

Pearlmutter, D., Krüger, E. L., and Berliner, P.: The role of evapotranspiration in the energy balance of an open-air scaled urban surface, Int. J. Climatol., 29, 911-920, 2009.

Pernes-Debuyser, A. and Tessier, D.: Soil physical properties affected by long-term fertilization, Eur. J. Soil Sci., 55, 505-512, https://doi.org/10.1111/j.1365-2389.2004.00614.x, 2004.

Perugini, L., Caporaso, L., Marconi, S., Cescatti, A., Quesada, B., de Noblet-Ducoudré, N., House, J. I., and Arneth, A.: Biophysical effects on temperature and precipitation due to land cover change, Environ. Res. Lett., 12, 053002, https://doi.org/10.1088/1748-9326/aa6b3f, 2017.

Phuleria, H. C., Fine, P. M., Zhu, Y. F., and Sioutas, C.: Air quality impacts of the October 2003 Southern California wildfires, J. Geophys. Res.-Atmos., 110, D07S20, https://doi.org/10.1029/2004JD004626, 2005.

Pielke, R. A., Avissar, S., Ron, I., Raupach, M. R., Dolman, A. J., Zeng, X., and Denning, A. S.: Interactions between the atmosphere and terrestrial ecosystems: influence on weather and climate, Glob. Change Biol., 4, 461-475, https://doi.org/10.1046/j.1365-2486.1998.t01-1-00176.x, 1998.

Pielke, R. A., Adegoke, J., Beltrán-Przekurat, A., Hiemstra, C. A., Lin, J., Nair, U. S., Niyogi, D., and Nobis, T. E.: An overview of regional land-use and landcover impacts on rainfall, Tellus B, 59, 587-601, https://doi.org/10.1111/j.1600-0889.2007.00251.x, 2007.

Pielke, R. A., Pitman, A., Niyogi, D., Mahmood, R., McAlpine, C., Hossain, F., Klein Goldewijk, K., Nair, U., Betts, R., Fall, S., Reichstein, M., Kabat, P., and de Noblet, N.: Land use/land cover changes and climate: modeling analysis and observational evidence: Land use/land cover changes and climate: modeling analysis and observational evidence, WIRES Clim. Change, 2, 828-850, https://doi.org/10.1002/wcc.144, 2011.

Pielke, S. R. A., Walko, R. L., Steyaert, L. T., Vidale, P. L., Liston, G. E., Lyons, W. A., and Chase, T. N.: The influence of anthropogenic landscape changes on weather in south Florida, Mon. Weather Rev., 127, 1663-1673, 1999.

Pitman, A. J., de Noblet-Ducoudré, N., Avila, F. B., Alexander, L. V., Boisier, J.-P., Brovkin, V., Delire, C., Cruz, F., Donat, M. G., Gayler, V., van den Hurk, B., Reick, C., and Voldoire, A.: Effects of land cover change on temperature and rainfall extremes in multi-model ensemble simulations, Earth Syst. Dynam., 3, 213 231, https://doi.org/10.5194/esd-3-213-2012, 2012a.

Pitman, A. J., Arneth, A., and Ganzeveld, L.: Regionalizing global climate models, Int. J. Climatol., 32, 321-337, https://doi.org/10.1002/joc.2279, 2012b.

Pongratz, J., Reick, C., Raddatz, T., and Claussen, M.: A reconstruction of global agricultural areas and land cover for the last millennium, Global Biogeochem. Cy., 22, Gb3018, https://doi.org/10.1029/2007gb003153, 2008.

Powers, J. S. and Schlesinger, W. H.: Relationships among soil carbon distributions and biophysical factors at nested spatial scales in rain forests of northeastern Costa Rica, Geoderma, 109, 165190, https://doi.org/10.1016/S0016-7061(02)00147-7, 2002.

Pressler, Y., Moore, J. C., and Cotrufo, M. F.: Belowground community responses to fire: meta-analysis reveals contrasting responses of soil microorganisms and mesofauna, Oikos, 128, 309327, https://doi.org/10.1111/oik.05738, 2019.

Prior, S. A., Runion, G. B., Marble, S. C., Rogers, H. H., Gilliam, C. H., and Torbert, H. A.: A Review of Elevated Atmospheric $\mathrm{CO}_{2}$ Effects on Plant Growth and Water Relations: Implications for Horticulture, HortScience, 46, 158-162, 2011.

Puma, M. J. and Cook, B. I.: Effects of irrigation on global climate during the 20th century, J. Geophys. Res., 115, D16120, https://doi.org/10.1029/2010JD014122, 2010.

Purves, D. W., Caspersen, J. P., Moorcroft, P. R., Hurtt, G. C., and Pacala, S. W.: Human-induced changes in US biogenic volatile organic compound emissions: evidence from longterm forest inventory data, Glob. Change Biol., 10, 1737-1755, https://doi.org/10.1111/j.1365-2486.2004.00844.x, 2004.

Rahdi, H., Assem, E., and Sharples, S.: On the colours and properties of building surface materials to mitigate urban heat islands in highly productive solar regions, Build. Environ., 72, 162-172, 2014.

Raison, R. J.: Modification of the soil environment by vegetation fires, with particular reference to nitrogen transformations: A review, Plant Soil, 51, 73-108, https://doi.org/10.1007/BF02205929, 1979.

Ramankutty, N. and Foley, A. J.: Estimating historical changes in global land cover: Croplands from 1700 to 1992, Global. Biogeochem. Cy., 13, 997-1027, 1999.

Randerson, J. T., Liu, H., Flanner, M. G., Chambers, S. D., Jin, Y., Hess, P. G., Pfister, G., Mack, M. C., Treseder, K. K., Welp, L. R., Chapin, F. S., Harden, J. W., Goulden, M. L., Lyons, E., Neff, J. C., Schuur, E. A. G., and Zender, C. S.: The impact of boreal forest fire on climate warming, Science, 314, 1130-1132, 2006.

Ray, D. K., Nair, U. S., Welch, R. M., Han, Q., Zeng, J., Su, W., Kikuchi, T., and Lyons, T. J.: Effects of land use in Southwest Australia: 1. Observations of cumulus cloudi- 
ness and energy fluxes, J. Geophys. Res.-Atmos., 108, 4414, https://doi.org/10.1029/2002JD002654, 2003.

Ray, D. K., Nair, U. S., Lawton, R. O., Welch, R. M., and Pielke, R. A.: Impact of land use on Costa Rican tropical montane cloud forests: Sensitivity of orographic cloud formation to deforestation in the plains, J. Geophys. Res.-Atmos., 111, 2108, https://doi.org/10.1029/2005JD006096, 2006.

Ren, C., Ng, E. Y., and Katzschner, L.: Urban climatic map studies: a review, Int. J. Climatol, 31, 2213-2233, https://doi.org/10.1002/joc.2237, 2011.

Ren, Y., Qu, Z., Du, Y., Xu, R., Ma, D., Yang, G., Shi, Y., Fan, X., Tani, A., and Guo, P.: Air quality and health effects of biogenic volatile organic compounds emissions from urban green spaces and the mitigation strategies, Environ. Pollut., 230, 849$861,2017$.

Rendón, A. M., Salazar, J. F., Palacio, C. A., Wirth, V., and Brötz, B.: Effects of Urbanization on the Temperature Inversion Breakup in a Mountain Valley with Implications for Air Quality, J. Appl. Meteorol. Climatol, 53, 840-858, https://doi.org/10.1175/JAMC-D-13-0165.1, 2014.

Richards, J. F.: Land transformation, in: The Earth as Transformed by Human Action, edited by: Turner II, N. L., Cambridge Univ. Press, New York, 1990.

Robinson, R. A. and Sutherland, W. J.: Post-war changes in arable farming and biodiversity in Great Britain, J. Appl. Ecol., 39, 157176, https://doi.org/10.1046/j.1365-2664.2002.00695.x, 2002.

Roschewitz, I., Gabriel, D., Tscharntke, T., and Thies, C.: The effects of landscape complexity on arable weed species diversity in organic and conventional farming: Landscape complexity and weed species diversity, J. Appl. Ecol., 42, 873-882, https://doi.org/10.1111/j.1365-2664.2005.01072.x, 2005.

Ruysschaert, G. R., Poesen, J., Verstraeten, G., and Govers, G.: Soil loss due to crop harvesting: significance and determining factors, Prog. Phys. Geogr., 28, 467-501, 2004.

Sacks, W. J. and Kucharik, C. J.: Crop management and phenology trends in the US Corn Belt: Impacts on yields, evapotranspiration and energy balance, Agr. Forest Meteorol., 151, 882-894, 2011.

Sacks, W. J., Cook, B. I., Buenning, N., Levis, S., and Helkowski, J. H.: Effects of global irrigation on the near-surface climate, Clim. Dynam., 33, 159-175, 2009.

Safford, R. J., Tran, T., Maltby, E., and Ni, D.: Status, biodiversity and management of the U Minh wetlands, Vietnam, Tropical Biodiversity, 5, 217-244, 1998.

Sagan, C., Toon, O., and Pollack James, B.: Anthropogenic albedo change and the Earths Climate, Science, 206, 1363-1368, 1979.

Salamanca, F., Georgescu, M., Mahalov, A., Moustaoui, M., and Martilli, A.: Citywide impacts of cool roof and rooftop solar photovoltaic deployment on near-surface air temperature and cooling energy demand, Bound.-Lay. Meteorol., 161, 203-221, 2016.

Salazar, L. F. and Nobre, C. A.: Climate change and thresholds of biome shifts in Amazonia, Geophys. Res. Lett., 37, L17706, https://doi.org/10.1029/2010GL043538, 2010.

Samuelson, L. J., Butnor, J., Maier, C., Stokes, T. A., Johnsen, K., and Kane, M.: Growth and physiology of loblolly pine in response to long-term resource management: defining growth potential in the southern United States, Can. J. Forest Res., 38, 721$732,2008$.
Santamouris, M.: Using cool pavements as a mitigation strategy to fight urban heat island - A review of the actual developments, Renew. Sust. Energ. Rev., 26, 224-240, 2013.

Sarrat, C., Lemonsu, A., Masson, V., and Guedalia, D.: Impact of urban heat island on regional atmospheric pollution, Atmos. Environ., 40, 1743-1758, 2006.

Saunois, M., Bousquet, P., Poulter, B., Peregon, A., Ciais, P., Canadell, J. G., Dlugokencky, E. J., Etiope, G., Bastviken, D., Houweling, S., Janssens-Maenhout, G., Tubiello, F. N., Castaldi, S., Jackson, R. B., Alexe, M., Arora, V. K., Beerling, D. J., Bergamaschi, P., Blake, D. R., Brailsford, G., Brovkin, V., Bruhwiler, L., Crevoisier, C., Crill, P., Covey, K., Curry, C., Frankenberg, C., Gedney, N., Höglund-Isaksson, L., Ishizawa, M., Ito, A., Joos, F., Kim, H.-S., Kleinen, T., Krummel, P., Lamarque, J.-F., Langenfelds, R., Locatelli, R., Machida, T., Maksyutov, S., McDonald, K. C., Marshall, J., Melton, J. R., Morino, I., Naik, V., O'Doherty, S., Parmentier, F.-J. W., Patra, P. K., Peng, C., Peng, S., Peters, G. P., Pison, I., Prigent, C., Prinn, R., Ramonet, M., Riley, W. J., Saito, M., Santini, M., Schroeder, R., Simpson, I. J., Spahni, R., Steele, P., Takizawa, A., Thornton, B. F., Tian, H., Tohjima, Y., Viovy, N., Voulgarakis, A., van Weele, M., van der Werf, G. R., Weiss, R., Wiedinmyer, C., Wilton, D. J., Wiltshire, A., Worthy, D., Wunch, D., Xu, X., Yoshida, Y., Zhang, B., Zhang, Z., and Zhu, Q.: The global methane budget 2000-2012, Earth Syst. Sci. Data, 8, 697-751, https://doi.org/10.5194/essd-8-697-2016, 2016.

Savadogo, P., Sawadogo, L., and Tiveau, D.: Effects of grazing intensity and prescribed fire on soil physical and hydrological properties and pasture yield in the savanna woodlands of Burkina Faso, Agr. Ecosyst. Environ., 118, 80-92, https://doi.org/10.1016/j.agee.2006.05.002, 2007.

Scalenghe, R. and Marsan, F. A.: The anthropogenic sealing of soils in urban areas, Landscape Urban Plan., 90, 1-10, https://doi.org/10.1016/j.landurbplan.2008.10.011, 2009.

Scheiter, S., Langan, L., and Higgins, S. I.: Nextgeneration dynamic global vegetation models: learning from community ecology, New Phytol., 198, 957-969, https://doi.org/10.1111/nph.12210, 2013.

Schneider, A., Friedl, M. A., and Potere, D.: A new map of global urban extent from MODIS satellite data, Environ. Res. Lett., 4, 044003, https://doi.org/10.1088/1748-9326/4/4/044003, 2009.

Schneider, N. and Eugster, W.: Climatic impacts of historical wetland drainage in Switzerland, Climatic Change, 80, 301-321, 2007.

Schroth, G., D'Angelo, S. A., Teixeira, W. G., Haag, D., and Lieberei, R.: Conversion of secondary forest into agroforestry and monoculture plantations in Amazonia: consequences for biomass, litter and soil carbon stocks after 7 years, Forest Ecol. Manage., 163, 131-150, https://doi.org/10.1016/S03781127(01)00537-0, 2002.

Segal, M. and Arritt, W. R.: Nonclassical mesoscale circulations caused by surface sensible heat-flux gradients, B. Am. Meteorol. Soc., 73, 1593-1604, 1992.

Segal, M., Avissar, R., McCumber, M. C., and Pielke, R. A.: Evaluation of vegetation effects on the generation and modification of mesoscale circulations, J. Atmos. Sci., 45, 2268-2293, 1988.

Segal, M., Pan, Z., Turner, R. W., and Takle, E. S.: On the potential impact of irrigated areas in North America on summer rainfall 
caused by large-scale systems, J. Appl. Meteorol., 37, 325-331, 1998.

Selmi, W., Weber, C., Rivière, E., Blond, N., Mehdi, L., and Nowak, D.: Air pollution removal by trees in public green spaces in Strasbourg city, France, Urban Forestry and Urban Greening, 17, 182201, 2016.

Senapati, N., Chabbi, A., Gastal, F., Smith, P., Mascher, N., Loubet, B., Cellier, P., and Naisse, C.: Net carbon storage measured in a mowed and grazed temperate sown grassland shows potential for carbon sequestration under grazed system, Carbon Manag., 5, 131-144, https://doi.org/10.1080/17583004.2014.912863, 2014.

Seto, K. C., Guneralp, B., and Hutyra, L. R.: Global forecasts of urban expansion to 2030 and direct impacts on biodiversity and carbon pools, P. Natl. Acad. Sci. USA, 109, 16083-16088, https://doi.org/10.1073/pnas.1211658109, 2012.

Shahmohamadi, P., Che-Ani, A. I., Ramly, A., Maulud, K. N. A., and Mohd-Nor, M. F. I.: Reducing urban heat island effects: A systematic review to achieve energy consumption balance, Int. J. Phys. Sci., 5, 626-636, 2010.

Sharratt, B., Feng, G., and Wendling, L.: Loss of soil and $\mathrm{PM}_{10}$ from agricultural fields associated with high winds on the Columbia Plateau, Earth Surf. Proc. Land., 32, 621-630, https://doi.org/10.1002/esp.1425, 2007.

Shashua-Bar, L. and Hoffman, M. E.: Vegetation as a climatic component in the design of an urban street. An empirical model for predicting the cooling effect of urban green areas with trees, Energ. Buildings, 31, 221-235, 2000.

Shen, S. and Leclerc, Y. M.: How large must surface inhomogeneities be before they influence the convective boundary layer structure? A case study, Q. J. Roy. Meteor. Soc., 121, 1209-1228, 1995.

Shepherd, J. M.: A review of current investigations of urbaninduced rainfall and recommendations for the future, Earth Interact., 9, 1-27, 2005.

Shepherd, J. M., Pierce, H., and Negri, A. J.: Rainfall modification by major urban areas: observations from spaceborne rain radar on the TRMM satellite, J. Appl. Meteorol., 41, 689-701, 2002.

Shriar, A. J.: Agricultural intensity and its measurement in frontier regions, Agroforest. Syst., 49, 301-318, https://doi.org/10.1023/A:1006316131781, 2000.

Shukla, J., Nobre, C., and Sellers, P.: Amazon deforestation and climate change, Science, 247, 1322-1325, 1990.

Silva, S. J., Heald, C. L., Geddes, J. A., Austin, K. G., Kasibhatla, P. S., and Marlier, M. E.: Impacts of current and projected oil palm plantation expansion on air quality over Southeast Asia, Atmos. Chem. Phys., 16, 10621-10635, https://doi.org/10.5194/acp-1610621-2016, 2016.

Singh, H. B., Cai, C., Kaduwela, A., Weinheimer, A., and Wisthaler, A.: Interactions of fire emissions and urban pollution over California: Ozone formation and air quality simulations, Atmos. Environ., 56, 45-51, https://doi.org/10.1016/j.atmosenv.2012.03.046, 2012.

Sini, J. F., Anquetin, S., and Mestayer, P. G.: Pollutant dispersion and thermal effects in urban street canyons, Atmos. Environ., 30, 2659-2677, https://doi.org/10.1016/1352-2310(95)00321-5, 1996.

Sitz, L. E., Di Sante, F., Farneti, R., Fuentes-Franco, R., Coppola, E., Mariotti, L., Reale, M., Sannino, G., Barreiro, M., Nogherotto, R., Giuliani, G., Graffino, G., Solidoro, C., Cos- sarini, G., and Giorgi, F.: Description and evaluation of the Earth System Regional Climate Model (Reg CM-ES): THE REGCM-ES MODEL, J. Adv. Model. Earth Sy., 9, 1863-1886, https://doi.org/10.1002/2017MS000933, 2017.

Smith, P., Cotrufo, M. F., Rumpel, C., Paustian, K., Kuikman, P. J., Elliott, J. A., McDowell, R., Griffiths, R. I., Asakawa, S., Bustamante, M., House, J. I., Sobocká, J., Harper, R., Pan, G., West, P. C., Gerber, J. S., Clark, J. M., Adhya, T., Scholes, R. J., and Scholes, M. C.: Biogeochemical cycles and biodiversity as key drivers of ecosystem services provided by soils, SOIL, 1, 665685, https://doi.org/10.5194/soil-1-665-2015, 2015.

Smith, P., House, J. I., Bustamante, M., Sobocká, J., Harper, R., Pan, G., West, P. C., Clark, J. M., Adhya, T., Rumpel, C., Paustian, K., Kuikman, P., Cotrufo, M. F., Elliott, J. A., McDowell, R., Griffiths, R. I., Asakawa, S., Bondeau, A., Jain, A. K., Meersmans, J., and Pugh, T. A. M.: Global change pressures on soils from land use and management, Glob. Change Biol., 22, 1008-1028, https://doi.org/10.1111/gcb.13068, 2016.

Snyder, P. K., Delire, C., and Foley, J. A.: Evaluating the influence of different vegetation biomes on the global climate, Clim. Dynam., 23, 279-302, 2004.

Song, J.: Phenological influences on the albedo of prairie grassland and crop fields, Int. J. Biometeorol., 42, 153-157, 1999.

Soussana, J.-F., Loiseau, P., Vuichard, N., Ceschia, E., Balesdent, J., Chevallier, T., and Arrouays, D.: Carbon cycling and sequestration opportunities in temperate grasslands, Soil Use Manage., 20, 219-230, https://doi.org/10.1111/j.14752743.2004.tb00362.x, 2006.

Spracklen, D. V. and Garcia-Carreras, L.: The impact of Amazonian deforestation on Amazon basin rainfall, Geophys. Res. Lett., 42, 9546-9552, 2015.

Stathopoulou, E., Mihalakakou, G., Santamouris, M., and Bagiorgas, H. S.: On the impact of temperature on tropospheric ozone concentration levels in urban environments, J. Earth Syst. Sci., 117, 227-236, 2008.

Stavrakou, T., Müller, J.-F., Bauwens, M., De Smedt, I., Van Roozendael, M., Guenther, A., Wild, M., and Xia, X.: Isoprene emissions over Asia 1979-2012: impact of climate and land-use changes, Atmos. Chem. Phys., 14, 4587-4605, https://doi.org/10.5194/acp-14-4587-2014, 2014.

Stéfanon, M., Schindler, S., Drobinski, P., de Noblet-Ducoudré, N., and D'Andrea, F.: Simulating the effect of anthropogenic vegetation land cover on heatwave temperatures over central France, Clim. Res., 60, 133-146, 2014.

Stella, P., Loubet, B., de Berranger, C., Charrier, X., Ceschia, E., Gerosa, G., Finco, A., Lamaud, E., Serça, D., George, C., and Ciuraru, R.: Soil ozone deposition: Dependence of soil resistance to soil texture, Atmos. Environ., 199, 202-209, https://doi.org/10.1016/j.atmosenv.2018.11.036, 2019.

Sterner, R. W., Elser, J. J., and Vitousek, P. M.: Ecological Stoichiometry: The Biology of Elements from Molecules to the Biosphere, https://doi.org/10.1515/9781400885695, 2017.

Stohlgren, T. J., Chase, T. N., Pielke, R. A., Kittel, T. G., and Baron, $\mathrm{J}$.: Evidence that local land use practices influence regional climate, vegetation, and stream flow patterns in adjacent natural areas, Glob. Change Biol., 4, 495-504, 1998.

Stone, B. and Norman, J. M.: Land use planning and surface heat island formation: A parcel-based radiation flux approach, Atmos. Environ., 40, 3561-3573, 2006. 
Stone, E.: The impact of timber harvest on soils and water, Report of the President's Advisory Panel on timber and the environment, US Government Printing Office, Washington, DC, 427467, 1973.

Stone, E.: Nutrient removals by intensive harvest - some research gaps and opportunities, in: Proceedings on the symposium on impacts of intensive harvesting on forest nutrient cycling, edited by: Leaf, A., 366-386, State University of New York, Syracuse, NY, 1979.

Strandberg, G. and Kjellström, E.: Climate Impacts from Afforestation and Deforestation in Europe, Earth Interact., 23, 1-27, https://doi.org/10.1175/EI-D-17-0033.1, 2019.

Sugimoto, S., Takahashi, H. G., and Sekiyama, H.: Modification of Near-Surface Temperature Over East Asia Associated With Local-Scale Paddy Irrigation, J. Geophys. Res.-Atmos., 124, 2665-2676, https://doi.org/10.1029/2018JD029434, 2019.

Suni, T., Guenther, A., Hansson, H. C., Kulmala, M., Andreae, M. O., Arneth, A., Artaxo, P., Blyth, E., Brus, M., Ganzeveld, L., Kabat, P., de Noblet-Ducoudré, N., Reichstein, M., Reissell, A., Rosenfeld, D., and Seneviratne, S.: The significance of land-atmosphere interactions in the Earth system iLEAPS achievements and perspectives, Anthropocene, 12, 6984, https://doi.org/10.1016/j.ancene.2015.12.001, 2015.

Sutton, M. A. (Ed.): The European nitrogen assessment: sources, effects, and policy perspectives, Cambridge University Press, Cambridge, UK, New York, 2011.

Sutton, M. A., Simpson, D., Levy, P. E., Smith, R. I., Reis, S., van Oijen, M., and de Vries, W.: Uncertainties in the relationship between atmospheric nitrogen deposition and forest carbon sequestration, Glob. Change Biol., 14, 2057-2063, https://doi.org/10.1111/j.1365-2486.2008.01636.x, 2008.

Sutton, M. A., Howard, C. M., Erisman, J. W., Billen, G., Bleeker, A., Greenfelt, P., Grizetti, B., Dise, N. B., and Van Grinsven, H.: Nitrogen as a threat to European terrestrial biodiversity, in: The European nitrogen assessment, edited by: Sutton, M. A., Howard, C. M., Erisman, J. W., and Bleeker, A., 463-494, Cambridge University Press, Cambridge, UK, 2011.

Swift, M. J., Izac, A.-M. N., and van Noordwijk, M.: Biodiversity and ecosystem services in agricultural landscapes - are we asking the right questions?, Agr. Ecosyst. Environ., 104, 113-134, https://doi.org/10.1016/j.agee.2004.01.013, 2004.

Taha, H.: Modelling impacts of increased urban vegetation on ozone air quality in the South Coast Air Basin, Atmos. Environ., 30, 3423-3430, 1996.

Taha, H.: Urban climates and heat islands: albedo, evapotranspiration, and anthropogenic heat, Energ. Buildings, 25, 99-103, 1997.

Taha, H., Wilkinson, J., Bornstein, R., Xiao, Q., McPherson, G., Simpson, J., Anderson, C., Lau, S., Lam, J., and Blain, C.: An urban-forest control measure for ozone in the Sacramento, CA Federal Non-Attainment Area (SFNA), Sustainable Cities and Society, 21, 51-65, https://doi.org/10.1016/j.scs.2015.11.004, 2016.

Tam, B. Y., Gough, W. A., and Mohsin, T.: The impact of urbanization and the urban heat island effect on day to day temperature variation, Urban Climate, 12, 1-10, https://doi.org/10.1016/j.uclim.2014.12.004, 2015.

Teuling, A. J., Seneviratne, S. I., Stöckli, R., Reichstein, M., Moors, E., Ciais, P., and Wohlfahrt, G.: Contrasting response of Euro- pean forest and grassland energy exchange to heatwaves, Nat. Geosci., 3, 722-727, 2010.

Thiery, W., Davin, E. L., Lawrence, D. M., Hirsch, A. L., Hauser, M., and Seneviratne, S. I.: Present-day irrigation mitigates heat extremes: irrigation mitigates heat extremes, J. Geophys. Res.-Atmos., 122, 1403-1422, https://doi.org/10.1002/2016JD025740, 2017.

Thies, C., Roschewitz, I., and Tscharntke, T.: The landscape context of cereal aphid-parasitoid interactions, P. Roy. Soc. B, 272, 203210, https://doi.org/10.1098/rspb.2004.2902, 2005.

Thomaz, E. L., Antoneli, V., and Doerr, S. H.: Effects of fire on the physicochemical properties of soil in a slash-and-burn agriculture, Catena, 122, 209-215, https://doi.org/10.1016/j.catena.2014.06.016, 2014.

Thornes, J., Bloss, W., Bouzarovski, S., Cai, X., Chapman, L., Clark, J., Dessai, S., Du, S., van der Horst, D., Kendall, M., Kidd, C., and Randalls, S.: Communicating the value of atmospheric services, Meteorol. Appl., 17, 243-250, https://doi.org/10.1002/met.200, 2010.

Tillman, D., Cassman, K. G., Matson, P. A., Naylor, R., and Polasky, S.: Agricultural sustainability and intensive production practices, Nature, 418, 671-677, https://doi.org/10.1038/nature01014, 2002.

Townsend, A. R., Cleveland, C. C., Houlton, B. Z., Alden, C. B., and White, J. W.: Multi-element regulation of the tropical forest carbon cycle, Front. Ecol. Environ., 9, 9-17, https://doi.org/10.1890/100047, 2011.

Trail, M., Tsimpidi, A. P., Liu, P., Tsigaridis, K., Hu, Y., Nenes, A., Stone, B., and Russell, A. G.: Reforestation and crop land conversion impacts on future regional air quality in the Southeastern U.S., Agr. Forest Meteorol., 209, 209-210, 2015.

Trentmann, J., Andreae, M. O., and Graf, H.-F.: Chemical processesin a young biomass-burning plume, J. Geophys. Res., 108, 4705-4715, 2003.

Turner, B. L.: Toward Integrated Land-Change Science - Advances in 1.5 Decades of Sustained International Research on Land-Use and Land-Cover Change, in: Advances in Global Environmental Change Research, edited by: Steffen, W., 21-26, Springer Verlag, Berlin, New York, 2002.

Turner, B. L., Skole, D., Sanderson, S., Fischer, G., Fresco, L., and Leemans, R.: Land-Use and Land-Cover Change Science/Research Plan, Joint publication of the International Geosphere-Biosphere Programme (Report No. 35) and the $\mathrm{Hu}-$ man Dimensions of Global, Stockholm, 1995.

United Nations: World Urbanization Prospects: The 2014 Revision, Highlights, 2014.

Usowicz, B., Lipiec, J., Łukowski, M., Marczewski, W., and Usowicz, J.: The effect of biochar application on thermal properties and albedo of loess soil under grassland and fallow, Soil Tillage Res., 164, 45-51, https://doi.org/10.1016/j.still.2016.03.009, 2016.

Vahmani, P. and Hogue, T. S.: Urban irrigation effects on WRF-UCM summertime forecast skill over the Los Angeles metropolitan area: URBAN IRRIGATION AND WRFUCM MODELING, J. Geophys. Res.-Atmos., 120, 9869-9881, https://doi.org/10.1002/2015JD023239, 2015.

Vahmani, P., Sun, F., Hall, A., and Ban-Weiss, G.: Investigating the climate impacts of urbanization and the potential for cool roofs to counter future climate change in Southern California, 
Environ. Res. Lett., 11, 124027, https://doi.org/10.1088/17489326/11/12/124027, 2016.

Val Martin, M., Heald, C. L., Lamarque, J.-F., Tilmes, S., Emmons, L. K., and Schichtel, B. A.: How emissions, climate, and land use change will impact mid-century air quality over the United States: a focus on effects at national parks, Atmos. Chem. Phys., 15, 2805-2823, https://doi.org/10.5194/acp15-2805-2015, 2015.

Vandermeer, J., Van Noordwijk, M., Anderson, J., Ong, C., and Perfecto, I.: Global change and multi-species agroecosystems: Concepts and issues, Agr. Ecosyst. Environ., 67, 1-22, https://doi.org/10.1016/S0167-8809(97)00150-3, 1998.

van Hulzen, J. B., Van Soelen, J., and Bouma, T. J.: Morphological variation and habitat modification are strongly correlated for the autogenic ecosystem engineerSpartina anglica (common cordgrass), Estuar. Coast., 30, 3-11, 2007.

Veldkamp, A., Altvorst, A. C., Eweg, R., Jacobsen, E., Kleef, A., Latesteijn, H., Mager, S., Mommaas, H., Smeets, P. J. A. M., Spaans, L., and Trijp, J. C. M.: Triggering transitions towards sustainable development of the Dutch agricultural sector: TransForum's approach, Agron. Sustain. Dev., 29, 87-96, https://doi.org/10.1051/agro:2008022, 2009.

Verbeke, T., Lathière, J., Szopa, S., and de Noblet-Ducoudré, N.: Impact of future land-cover changes on $\mathrm{HNO}_{3}$ and $\mathrm{O}_{3}$ surface dry deposition, Atmos. Chem. Phys., 15, 13555-13568, https://doi.org/10.5194/acp-15-13555-2015, 2015.

Verburg, P. H., Neumann, K., and Nol, L.: Challenges in using land use and land cover data for global change studies: LAND USE AND LAND COVER DATA FOR GLOBAL CHANGE STUDIES, Glob. Change Biol., 17, 974-989, https://doi.org/10.1111/j.1365-2486.2010.02307.x, 2011.

Verma, S. and Jayakumar, S.: Impact of forest fire on physical, chemical and biological properties of soil: A review, Proceedings of the International Academy of Ecology and Environmental Sciences, 2, 168, 2012.

Vico, G., Revelli, R., and Porporato, A.: Ecohydrology of street trees: design and irrigation requirements for sustainable water use, Ecohydrology, 7, 508-523, https://doi.org/10.1002/eco.1369, 2014.

Vinatier, F., Gosme, M., and Valantin-Morison, M.: A tool for testing integrated pest management strategies on a tritrophic system involving pollen beetle, its parasitoid and oilseed rape at the landscape scale, Landscape Ecol., 27, 1421-1433, https://doi.org/10.1007/s10980-012-9795-3, 2012.

Vitousek, P. M. and Denslow, J. S.: Nitrogen and phosphorus availability in treefall gaps of a lowland tropical rainforest, J. Ecol., 74, 1167-1178, 1986.

Vitousek, P. M. and Matson, P. A.: Disturbance, Nitrogen Availability, and Nitrogen Losses in an Intensively Managed Loblolly Pine Plantation, Ecology, 66, 1360-1376, https://doi.org/10.2307/1939189, 1985.

Vollhardt, I. M. G., Tscharntke, T., Wäckers, F. L., Bianchi, F. J. J. A., and Thies, C.: Diversity of cereal aphid parasitoids in simple and complex landscapes, Agr. Ecosyst. Environ., 126, 289-292, https://doi.org/10.1016/j.agee.2008.01.024, 2008.

Volo, T. J., Vivoni, E. R., Martin, C. A., Earl, S., and Ruddell, B. L.: Modelling soil moisture, water partitioning, and plant water stress under irrigated conditions in desert urban areas, Ecohydrology, 7, 1297-1313, https://doi.org/10.1002/eco.1457, 2014.
Von Randow, C., Manzi, A. O., Kruijt, B., De Oliveira, P. J., Zanchi, F. B., Silva, R. L., Hodnett, M. G., Gash, J. H. C., Elbers, J. A., Waterloo, M. J., Cardoso, F. L., and Kabat, P.: Comparative measurements and seasonal variations in energy and carbon exchange over forest and pasture in South West Amazonia, Theor. Appl. Climatol, 78, 5-26, 2004.

Wagle, R. F. and Kitchen, J. H.: Influence of Fire on Soil Nutrients in a Ponderosa Pine Type, Ecology, 53, 118-125, https://doi.org/10.2307/1935716, 1972.

Wagner, P. and Schäfer, K.: Influence of mixing layer height on air pollutant concentrations in an urban street canyon, Urban Climate, 22, 64-79, https://doi.org/10.1016/j.uclim.2015.11.001, 2017.

Wang, J., Bras, R. L., and Eltahir, E. A.: The impact of observed deforestation on the mesoscale distribution of rainfall and clouds in Amazonia, J. Hydrometeorol., 1, 267-286, 2000.

Wang, J., Chagnon, F. J., Williams, E. R., Betts, A. K., Renno, N. O., Machado, L. A., Bisht, G., Knox, R., and Bras, R. L.: Impact of deforestation in the Amazon basin on cloud climatology, P. Natl. Acad. Sci. USA, 106, 3670-3674, 2009.

Wang, L., Gao, Z., Miao, S., Guo, X., Sun, T., Liu, M., and Li, D.: Contrasting characteristics of the surface energy balance between the urban and rural areas of Beijing, Adv. Atmos. Sci., 32, 505$514,2015$.

Warwick, N. J., Archibald, A. T., Ashworth, K., Dorsey, J., Edwards, P. M., Heard, D. E., Langford, B., Lee, J., Misztal, P. K., Whalley, L. K., and Pyle, J. A.: A global model study of the impact of land-use change in Borneo on atmospheric composition, Atmos. Chem. Phys., 13, 9183-9194, https://doi.org/10.5194/acp-13-9183-2013, 2013.

Weaver, C. P. and Avissar, R.: Atmospheric disturbances caused by human modification of the landscape, B. Am. Meteorol. Soc., 82, 269-282, 2001.

Westra, D., Steeneveld, G. J., and Holtslag, A. A. M.: Some observational evidence for dry soils supporting enhanced relative humidity at the convective boundary layer top, J. Hydrometeorol., 13, 1347-1358, 2012.

Wiegand, T., Moloney, K., Naves, J., and Knauer, F.: Finding the Missing Link between Landscape Structure and Population Dynamics: A Spatially Explicit Perspective, Am. Nat., 154, 605627, https://doi.org/10.1086/303272, 2000.

Wiegand, T., Revilla, E., and Moloney, K. A.: Effects of Habitat Loss and Fragmentation on Population Dynamics, Conserv. Biology, 19, 108-121, https://doi.org/10.1111/j.15231739.2005.00208.x, 2005.

Wiernga, J.: Representative roughness parameters for homogeneous terrain, Bound.-Lay. Meteorol., 63, 323-363, https://doi.org/10.1007/BF00705357, 1993.

Wilhelm, M., Davin, E. L., and Seneviratne, S. I.: Climate engineering of vegetated land for hot extremes mitigation: An Earth system model sensitivity study, J. Geophys. Res.-Atmos., 120, 2612-2623, 2015.

Wilson, E. and Piper, J.: Spatial planning and climate change, Abingdon/New York, Routledge, 2010.

Woodwell, G. M., Hobbie, J. E., Houghton, R. A., Melillo, J. M., Moore, B., and Peterson, B. J.: Global deforestation: contribution to atmospheric carbon dioxide, Science, 222, 1081-1086, 1983.

Wright, A. L., Hons, F. M., and Rouquette, F. M.: Long-term management impacts on soil carbon and nitrogen dynamics of grazed 
bermudagrass pastures, Soil Biol. Biochem., 36, 1809-1816, 2004.

Xia, L., Lam, S. K., Wolf, B., Kiese, R., Chen, D., and Butterbach-Bahl, K.: Trade-offs between soil carbon sequestration and reactive nitrogen losses under straw return in global agroecosystems, Glob. Change Biol., 24, 5919-5932, https://doi.org/10.1111/gcb.14466, 2018.

Yang, J., McBride, J., Zhou, J., and Sun, Z.: The urban forest in Beijing and its role in air pollution reduction, Urban Forestry and Urban Greening, 3, 65-78, 2005.

Yang, J. Y., Drury, C. F., Yang, X. M., De Jong, R., Huffman, E. C., and Campbell, C. A.: Estimating biological $\mathrm{N}_{2}$ fixation in Canadian agricultural land using legume yields, Agr. Ecosyst. Environ., 137, 192-201, 2010.

Yao, R., Wang, L., Huang, X., Gong, W., and Xia, X.: Greening in Rural Areas Increases the Surface Urban Heat Island Intensity, Geophys. Res. Lett., 46, 2204-2212, https://doi.org/10.1029/2018GL081816, 2019.

Yeh, S., Jordaan, S. M., Brandt, A. R., Turetsky, M. R., Spatari, S., and Keith, D. W.: Land Use Greenhouse Gas Emissions from Conventional Oil Production and Oil Sands, Environ. Sci. Technol., 44, 8766-8772, https://doi.org/10.1021/es1013278, 2010.

Yevich, R. and Logan, J. A.: An assessment of biofuel use and burning of agricultural waste in the developing world, Global Biogeochem. Cy., 17, 1095, https://doi.org/10.1029/2002GB001952, 2003.

Yew, F.-K., Sundram, K., and Basiron, Y.: Estimation of GHG emissions from peat used for agriculutre with a special refernece to oil palm, Journal of Oil Palm and The Environment, 17, 2010.

Yokelson, R. J., Bertschi, I. T., Christian, T. J., Hobbs, P. V., Ward, D. E., and Hao, W. M.: Trace gas measurements in nascent, aged, and cloud processed smoke from African savanna fires by airborne Fourier transform infrared spectroscopy (AFTIR), J. Geophys. Res.-Atmos., 108, 8478, https://doi.org/10.1029/2002JD002322, 2003.

Zaehle, S. and Dalmonech, D.: Carbon-nitrogen interactions on land at global scales: current understanding in modelling climate biosphere feedbacks, Curr. Opin. Env. Sust., 3, 311-320, https://doi.org/10.1016/j.cosust.2011.08.008, 2011.
Zampieri, M. and Lionello, P.: Anthropic land use causes summer cooling in Central Europe, Clim. Res., 46, 255-268, https://doi.org/10.3354/cr00981, 2011.

Zhang, Y., Pang, X., Xia, J., Shao, Q., Yu, E., Zhao, T., She, D., Sun, J., Yu, J., Pan, X., and Zhai, X.: Regional Patterns of Extreme Precipitation and Urban Signatures in Metropolitan Areas, J. Geophys. Res.-Atmos., 124, 641-663, https://doi.org/10.1029/2018JD029718, 2019.

Zhong, S., Qian, Y., Sarangi, C., Zhao, C., Leung, R., Wang, H., Yan, H., Yang, T., and Yang, B.: Urbanization Effect on Winter Haze in the Yangtze River Delta Region of China, Geophys. Res Lett., 45, 6710-6718, https://doi.org/10.1029/2018GL077239, 2018.

Zhou, W. Q., Qian, Y. G., Li, X. M., Li, W. F., and Han, L. J.: Relationships between land cover and the surface urban heat island: seasonal variability and effects of spatial and thematic resolution of land cover data on predicting land surface temperatures, Landscape Ecol., 29, 153-167, https://doi.org/10.1007/s10980013-9950-5, 2014.

Zhu, L., Henze, D. K., Bash, J. O., Cady-Pereira, K. E., Shephard, M. W., Luo, M., and Capps, S. L.: Sources and Impacts of Atmospheric $\mathrm{NH}_{3}$ : Current Understanding and Frontiers for Modeling, Measurements, and Remote Sensing in North America, Curr. Pollution Rep., 1, 95-116, https://doi.org/10.1007/s40726-0150010-4, 2015.

Zhu, Y., Zhan, Y., Wang, B., Li, Z., Qin, Y., and Zhang, K.: Spatiotemporally mapping of the relationship between $\mathrm{NO}_{2}$ pollution and urbanization for a megacity in Southwest China during 2005-2016, Chemosphere, 220, 155-162, https://doi.org/10.1016/j.chemosphere.2018.12.095, 2019.

Zinke, P. J.: The Pattern of Influence of Individual Forest Trees on Soil Properties, Ecology, 43, 130-133, https://doi.org/10.2307/1932049, 1962.

Ziska, L. H. and George, K.: Rising carbon dioxide and invasive, noxious plants: potential threats and consequences, World Resource Review, 16, 427-447, 2004. 